Geology and

Larger Foraminifera

of Saipan Island

GEOLOGICAL SURVEY PROFESSIONAL PAPER 253

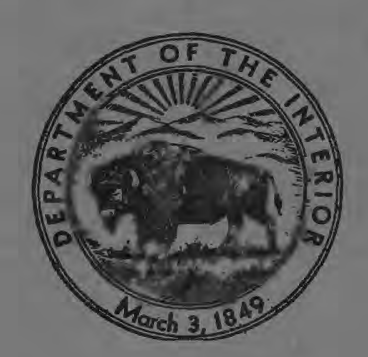




\section{Geology and}

\section{Larger Foraminifera}

\section{of Saipan Island}

By W. STORRS COLE and JOSIAH BRIDGE

GEOLOGICAL SURVEY PROFESSIONAL PAPER 253

A preliminary report on the geology of this interesting island in the Mariana Islands, Trust Territory of the Pacific, and descriptions of some of the larger microfossils 


\section{UNITED STATES DEPARTMENT OF THE INTERIOR}

Douglas McKay, Secretary

GEOLOGICAL SURVEY

W. E. Wrather, Director

For sale by the Superintendent of Documents, U. S. Government Printing Office Washington 25, D. C 


\section{CONTENTS}

Abstract.

General introduction

Geography and geology of Saipan

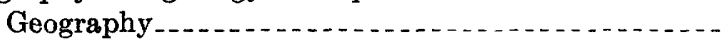

Location

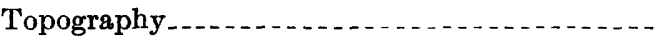

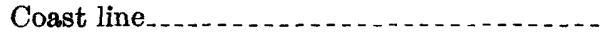

Terrace platform

Central Divide. . . . . . . . . . . . . . . . .

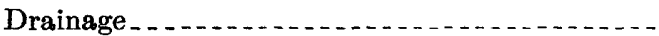

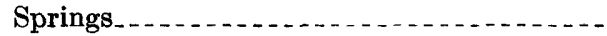

Lakes and Swamps. . . . . . . .

Geology

Stratigraphy ..........

Basal volcanic rocks....................

Matansa limestone..........................

Densinyama formation................

Laulau limestone. . . . . . . . . . . . . . .

Donni tuff ...............................

Tagpochau limestone...................

Naftan limestone. ......................

Mariana limestone ......................

Limestones of uncertain age
Page

Geography and geology of Saipan-Continued

Geology-Continued

Recent deposits.

Structural features

Correlation and systematic paleontology .............

Introduction . . . . . .

Stratigraphy .........

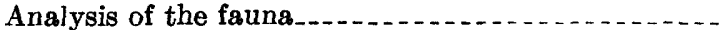

Eocene..............

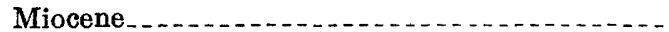

Pliocene-Pleistocene..........................

Systematic descriptions..........

Miliolidae.........

Camerinidae. . . . . . . .

Peneroplidae.

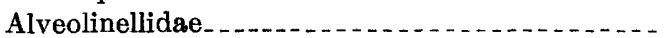

Rotaliidse...

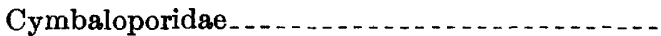

Victoriellidae............

Orbitoididae..............

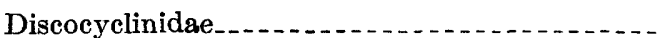

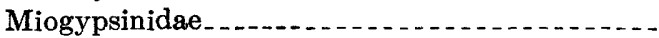

Literature cited.

40

Index .......... 43

\section{ILLUSTRATIONS}

[Plates 2-15 follow index]

Prate 1. Geologic map of Saipan.

2. Heterostegina and Camerina.

3. Spiroclypeus.

4. Spiroclypeus, Operculina, and Heterostegina.

5. Operculina, Streblus, Spiroclypeus, and Cycloclypeus.

6. Pellatispira and Biplanispira.

7. Lepidocyclina and Spiroclypeus.

8. Lepidocyclina, Spiroclypeus, and Miogypsinoides.

9-11. Lepidocyclina.

12. Asterocyclina, Disocyclina, Lepidocyclina, Sorites, and Borelis.

13. Miogypsinoides, Miogypsina, and Borelis.

14. Sorites, Lepidocyclina, Victoriella, Cycloclypeus, Spiroclypeus, Miogypsina, Miogypsinoides, and Austrotrillina.

15. Fabiana, Pellatispira, and Asterocyclina.

\section{TABLES}

TABLE 1. Distribution of limestone units in the southern Mariana Islands

2. Columnar section for Saipan.

3. Small Foraminifera from the Donni tuff

4. Distribution of species of Larger Foraminifera on Saipan Island.

5. Measurements of specimens referred to Lepidocyclina (Nephrolepidina) parva Oppenoorth. 



\title{
GEOLOGY AND LARGER FORAMINIFERA OF SAIPAN ISLAND
}

\author{
By W. Storrs Cole and Josiah Bridget
}

\begin{abstract}
The first part of this paper briefly describes the geography and geology of Saipan Island, based largely upon reconnaissance by Bridge and Piper in 1946.

Saipan has an area of about $46 \mathrm{sq} \mathrm{mi}$ and is the second largest island of the Mariana Islands, being exceeded only by Guam. Three distinct topographic provinces may be recognized; a coastal plain and fringing reef which is especially well developed along the western coast, a Terrace Platform developed along the southern, eastern, and northern coasts, which is bordered by cliffs and whose surface stands at various altitudes up to 300 feet above sea level, and a Central Divide which reaches a maximum altitude of about 1,555 feet on Mount Tagpochau in the central part of the island. The island is conspicuously terraced, the terraces being best developed along the eastern side. Some of the terrace surfaces represent uplifted, limestone covered, reef flats; some are the product of erosion; and others are product of both erosion and deposition.

Graded drainage systems are developed only in the areas underlain by igneous rocks; on the limestone flats most of the runoff disappears into sinks and crevices, and solution is the dominant force in the modification of these surfaces. Springs, some of them of moderately large size, are fairly common at the contact of the limestones and the igneous rocks.
\end{abstract}

The oldest rocks exposed on Saipan are a series of lava flows and associated pyroclastics of Eocene age. They are exposed principally in the Central Divide, but also crop out in small areas at $a$ few other localities. They are overlain by a series of marine sediments, chiefly limestones, with some interbedded conglomerates, tuffs, sandstones, and shales. The limestones themselves vary greatly from place to place and represent deposits lsid down in several different environments. The older limestones, of Eocene and Miocene age, grade laterally into, and are interbedded with tuffs and agglomerates, thus suggesting that vulcanism extended into Miocene time. Post-Miocene sediments are free from interbedded pyroclastic material. In gereral the older sediments crop out in the Central Divide. They also appear in small patches at other localities, largely as the result of faulting and erosion.

The formations recognized by the Japanese geologists, the localities from which samples were collected, and the limestone samples themselves are briefly described.

The general structure of the island is also discussed.

In the second part of this paper 38 species of larger Foraminifera are described, including 5 new ones and 5 too incomblete for positive identification. Most of the species are Miocen? forms, but 4 samples contain an Eocene fauna and 3 have Plio-Pleistocene faunas. Most of the Miocene samples are assigned to the Aquitanian (Tertiary "e"), but there is the possibility that the Burdigalian (Tertiary "f "), is represented by 4 samples.

\section{GENERAL INTRODUCTION}

In 1946, Bridge, while a member of the U. S. Commercial Company's Economic Survey of Micronesia, made two brief visits to Saipan, May 18-22 and July 20-27. On the second trip he was accompanied by Arthur M. Piper, also on detail from the U. S. Geological Survey to the Economic Survey. Among the collections made on these trips were 24 samples of limestone representing various stratigraphic units and these, at the conclusion of the trip, were turned over to Cole for faunal study. In addition to these specimens, Cole also had a specimen of limestone from Saipan collected by H. T. Stearns of the U. S. Geological Survey, who was on duty with the U. S. Navy in 1944; and a few specimens collected by Bridge on Tinian in the Mariana Islands.

In this paper, Cole has prepared the parts on the descriptions of the species and the correlation of the limestones, and Bridge the sections on geography and geology. The map (pl. 1) has been prepared from various sources. The topographic base has been adapted from Japanese and United States military maps supplemented by information compiled from uncortrolled aerial photographs. The nomenclature has been revised in accordance with the "Preliminary Gazetteer of Geographic Names for Saipan" (Cloud, 1949). Minor differences in spelling of place names have been corrected in accordance with the spelling in the above mentioned report, and where these changes are ohvious, no comment is made; however, names appearing in Japanese reports that differ greatly from the native names given in Cloud's gazetteer are given in parentheses at appropriate places in order to clarify references 
to Japanese texts and translations. For the convenience of the reader the nomenclature in the text has been simplified by the substitution of English generic nouns, as mount, cliff, spring, stream, ravine, beach, and point, for most of the Chamorro terms used by Cloud, but both the Chamorro and English names appear on the map.

A thorough study of the geology of Saipan was made by a party under the leadership of P. E. Clour, Jr. in 1948-49. This project was under the auspicies of the Pacific Mapping Program of the U. S. Geological Survey, in cooperation with the Corps of Engineers, U. S. Army. With the exception of the gazetteer, the results of this project were not available to the authors.

\section{ACKNOWLEDGMENTS}

The authors are indebted to Cmdr. L. G. Findley, U. S. N. R., Commanding Officer, U. S. Naval Military Government Unit, Saipan, and to the officers of his unit, and to Frank C. Brown, Saipan representative of the U. S. Commercial Co., for furnishing quarters, transportation, and other assistance to the members of the field party.

They also wish to thank A. M. Piper of the U. S. Geological Survey for permission to use information from his geologic map of Saipan and from his report on the water resources of the island, and 1 4iss M. Ruth Todd of the U.S. Geological Survey for identifying the smaller Foraminifera from the Donni tuff. 


\title{
GEOGRAPHY AND GEOLOGY OF SAIPAN
}

\author{
By Josiah Bridge
}

\section{GEOGRAPHY}

\section{LOCATION}

Saipan is the second largest of the Mariana Islands, a chain of islands in the western Pacific Ocean forming a part of the boundary between the Pacific Ocean proper, and the Philippine Sea. It lies between $15^{\circ} 06^{\prime}$ and $15^{\circ} 17^{\prime}$ north latitude, and between $142^{\circ} 42^{\prime}$ and $142^{\circ} 50^{\prime}$ east longitude. It is about 125 nautical miles north $30^{\circ}$ east of Guam. Its nearest neighbor, Tinian, lies to the southwest and is separated from it by the Saipan Channel, which is about 3 miles wide at its narrowest point.

Saipan is a long, narrow, hilly island, whose general outline has somewhat the shape of a spanner wrench, the two jaws being represented by Hagman and Dandan Points (Tayama, 1938). The long axis of the island trends $\mathrm{N} .30^{\circ} \mathrm{E}$., parallel to the general trend of the Mariana chain in these latitudes. The island is about 12.7 miles long, 5.5 miles wide at the widest point near the southern end, and narrows to an average width of 2.75 miles. Its area is about 47 square miles (Bryan, 1946).

\section{TOPOGRAPHY}

Seen at a distance from the east or west, Saipan appears as a high, rugged island, whose slopes are carved into a series of flat terrace surfaces, rising steplike one upon the other and separated by cliffs or steep slopes. From the south the profile of the island is distinctly conical.

On close approach two distinct physiographic provinces may be distinguished: a broad base whose summit is formed by an ascending series of terrace levels rising from about 150 to 300 feet above sea level (here called the Terrace Platform), and a rugged, less conspicuously terraced range of hills (here called the Central Divide), rising above and encircled on three sides by the Terrace Platform. For purposes of description the topography will be discussed under these headings: (1) the coast line, consisting of cliffs, beaches, coastal flat marshes, and bordering reefs; (2) the Terrace Platform; and (3) the Central Divide together with other isolated hills that stand on and rise above the Terrace Platform.

\section{COAST IINE}

Along the northern, eastern, and southern sides of the island, the coast is steeply cliffed, the cliffs ranging from a few feet to more than 200 feet in height. In son 9 areas a series of two to four cliffs is separated by narrow benches or ramps; in others the entire ascent to the summit of the Terrace Platform forms a sing's cliff. Many of these cliffs rise directly from the water's edge, and many are strongly undercut at sea level. Cliffs that rise from the surfaces of some of the lower terraces are also notched at the base, and some of the terrace surfaces support small stacks indicating that some of the lowest terrace levels, at least, are largely wave cut. Examples of notched siacks can be seen along the east coast south of South Fahang Valley.

Beaches are few, small, narrow, and discontinuous, their width commonly being measured in a few tens of feet, and their landward margins commonly abutting against a cliff. In general, they are restricted to the heads of small, protected bays and around the mouths of streams. The largest of these beaches are on the northern side of Laulau (Magicienne) Bay, and they differ from most of the others in that their landward margins terminate in a ramp leading to the next terrace level rather than against a cliff.

Along these same coasts, the fringing reef is also very narrow, or wanting, its width seldom exceeds 100 feet and generally is much less. In the protected are along the north shore of Laulau Bay, and again along the south shore between Naftan and Obyan Points, the reef flat reaches a width of 500 to 600 feet, but this is exceptional. Beyond the reef the seaward slopes descend abruptly into deep water, the 100 fathem line lying less than a mile off-shore throughout most of this area. No barrier reef is present.

The western coast, for a distance of 9 or 10 miles between Agingan Point south of Chalan Kanoa and Matansa settlement north of Tanapag, is low, and much of it is bordered by sand beaches or by low cliffs, commonly less than 5 feet high. These grade landward into a low coastal flat whose surface averages less than 25 feet above sea level, and whose width averages about 0.25 mile, but locally exceeds 1 mile. South of Garapan the landward margin of this plain is connected to the summit of the Terrace Platform by steep slopes and low cliffs, generally with intermediate benches. East and north of Garapan, the landward margin of the coastal plain, commonly merges with the steep western slopes of the Central Divide, although locally the transition is marked by a few narrow terraces at different lerels. 
On the seaward side this coastal flat is bordered throughout its entire length by a reef, whose outer margin lies 14 mile to more than 2 miles off-shore, diverging from the fringing reef at Agingan Point and rejoining it at Magpi Point about 2 miles southwest of the northern tip of the island. This reef encloses a shallow lagoon in which the average depth of the water is about 6 feet. A few channels through this reef give access to a small improved harbor between Garapan and Tanapag, capable of handling small and medium sized vessels. To the west of the reef a shelf lies in water that averages less than 50 fathoms in depth. It is $3 \frac{1}{2}$ to 5 miles wide, and part of it forms the unprotected Saipan harbor used by large vessels (Hydrographic Office Chart 6060).

\section{TERRACE PLATFORM}

This is a series of terrace levels, ranging locally from one to six in number, and standing at altitudes ranging from 3 to more than 200 feet above sea level. They almost encircle the island, being best developed on the southern third to the south of Mount Tagpochau; in the central part of the Hagman peninsula, and at the northeastern tip, northeast of Pidos Kalahe (Mount Marpi). The eastern coast between Hagman Point and Pidos Kalahe is also bordered by well-defined, narrow terraces, but along the western coast in the general vicinity of Garapan these lower terraces are poorly preserved and locally absent.

In most places the various terrace levels are separated by cliffs, less commonly by steep ramps. At other places one terrace grades imperceptably into another. Many of the cliffs separating the levels are erosion features, commonly raised sea cliffs, others are probably fault line scarps. (pp. 14-15).

In the southern part of the islanid the surface of the Terrace Platform is broken into several levels by normal faults downthrown to the west, whose courses are marked by lines of low cliffs such as those extending north-northeast from Agingan and Obyan Points. The lack of the Terrace Platform along much of the west side of the island may also be due to faulting. (p. 15).

Although Tayama has recognized six terrace levels between sea level and the summit of the Terrace Platform, he actually combines them into three general levels which stand approximately 3 to 15,65 to 100 , and 130 to nearly 300 feet respectively above sea level.

\section{CENTRAL DIVIDE}

The dominant topographic feature of Saipan is Mount Tagpochau, 1,555-1,560 feet which stands just south of the center of the island, and rises abruptly above the Terrace Platform that almost encircles it. Seen from the south at a distance of a few miles it resembles a volcanic cone, but this is ar illusion, for the mountain is composed largely of limestone and on closer approach narrow terraces can be seen at several levels. The mountain is the highest part of a long, narrow, moderately rugged ridge that extends from a point about 1.5 miles east of Susupe Point, northeastward to Pidos Kalahe (Mount Marpi), 833 feet, near the northern end of the island. The ritge is asymmetric, the steeper slope being on the western side, and forms the backbone of the northern two-thirds of the island. It is here termed the Central D vide. All of its summits exceed 700 feet above sea level, and the lowest pass across it has a summit altitude of about 500 feet.

Tayama has recognized seven terrace levels in the Central Divide above the summit level of the Terrace Platform, and has combined these into five terrace stages whose altitudes are 330 to 350,400 to 460,820 to 980,1070 to 1150 , and 1312 to 1560 feet above sea level respectively.

Two other small, but conspicuous hills rise above the general level of the Terrace Platform. Whese are the summits of Naftan and Hagman peninsulas, with altitudes of 407 and 4.82 feet above sea level respectively. Both are capped by limestones, are conspicuously terraced, and are actually portions of the Terrace Platform that have been raised to their present altitudes by faulting.

The minor topographic features of the Central Divide vary greatly within short distances and are directly related to the underlying rocks. At the northern and southern ends of the ridge, limestone formations predominate and the resultant topography is a series of flat or gently tilted terrace surfaces separated by steeper slopes or in many places, cliffs.

In the central part of this ridge, for a distance of about 2.5 miles between the Cross-islend Highway and the north slope of Mount Achugau, the crest and slopes of the Central Divide are largely underlain by volcanic rocks, consisting primarily of tuffs in the southern part and of rhyolite flows around Mount Achugau. In this area the terrace leve's are poorly preserved, cliffs are uncommon, and both the eastern and western slopes are thoroughly dissected by intricate networks of ravines and gullies.

\section{DRATNAGF}

Two strongly contrasting drainage types are found on Saipan, one characteristic of the limestone surfaces of the Terrace Platform and subordinately developed along the surfaces of minor terraces, the other characteristic of the hilly areas of the Central Divide t $\mathrm{l}$ at are underlain largely by volcanic rocks. 
There is no well-developed drainage system on the surface of the Terrace Platform. Locally, small ravines notch the cliffs around its edges and on its surface, and shallow, poorly defined channels drain southwestward at the bases of the fault line scarps east of Chalan Kanoa, but none of these contain permanent streams. Over most of the area, however, rainfall quickly disappears into sinks and crevices in the limestone. Solution is a dominant factor in the erosion and sculpturing of the surface. The amount of solution is indicated by the rampart that generally borders the outer edge of the terraces, particularly where these terminate in a cliff. These rims have been observed on the edge of limestone terraces in many islands in the Pacific (Hoffmeister and Ladd, 1945), and are especially well developed on Okinawa (MacNeil, personal communication, 1951). On Saipan they are especially well developed at the northeastern end of the island along the upper edge of Bañadero Cliff, where they stand from 6 to 10 feet above the general terrace level and form a natural rampart. That these are solution rather than erosional or original features is indicated by the fact that some of the terrace surfaces behind them are studded with limestone pinnacles, broad at the base and tapering upward, which rise to about the same height as the rampart and which are clearly remnants left by the solution. These "solution pinnacles" may be distinguished from stacks by their general shape, particularly by the lack of an undercut base, and by the fact they are protected on the seaward side by the rampart just referred to. They are not common on Saipan but are well developed on certain levels on the eastern side of Tinian, especially on the 440-foot terrace east of Lasso Hill, and on the summit of Carolinas Hill in the central and southeastern parts of the island.

The surfaces of the smaller and higher terraces developed upon limestone are likewise sculptured largely by solution and are devoid of orderly drainage patterns. Tayama (1938) has raised a question as to whether these rims are original constructional features of reef building, or the results of erosion. He does not mention solution as a possible cause and seems to be somewhat skeptical of the ability of "erosion" to produce such a topography. To the writer, the evidence cited in favor of solution as the dominant factor in the development of these ramparts appears to be fairly conclusive.

Well-graded drainage systems are developed along the east and west slopes of the Central Divide, particularly in the part underlain by igneous rocks. There are about ten such systems along the eastern side of the divide between the west end of Laulau Mountain and the Madog Cliffs, and about eleven systems on the west side of the divide between Susupe (Aefetna) Point on the south and Magpi Point to the north. The streams on the eastern side of the divide are longer and much better developed than those on the western side but apparently only three of them are permanent streams. The others are dry gullies except after heavy rains. On the west side none of the eleven systems carry permanent streams.

The surfaces of many of the higher terraces are now developed on limestone along their outer margins and on volcanic beds farther inland. This is also true of the surface of the Terrace Platform along the east coast between Halaihai and Talofofo Valleys. Whare this situation occurs, the thin landward edge of the original limestone surface has been eroded away and the softer volcanic rocks have been profoundly dissected and none of the original flat terrace surface remains. On the other hand the parts of these terraces on wrich the limestone cover is still preserved, are little dissected, and their surfaces commonly stand slightly atove the dissected level on the volcanic rocks and are senarated from them by a low inward-facing cliff. Good examples of this may be seen in the terrace defended by the Adelug and Machegit Cliffs east of Mount Tagpochau, and by the surface of the Terrace Platform itself in the Halaihai district. These limestone-defended terraces are among the most interesting topographic features of the island and they constitute a most formidable obstacle to invading forces.

In the upper reaches of each drainage system, developed on the volcanic rocks, a typical network of dendritic tributaries is developed. These all join th $a$ main valley at or near the point where it crosses onto the surface of the Terrace Platform, and from her? to the sea the valley is commonly a deep, narrow, stesp-sided canyon with few or no tributaries in this part of the course. This development is particularly ncticeable on the eastern side of the island, in the gorges of Talofofo, Donnai and Halaihai streams.

This feature is repeated where certain streams cross the fronts of the narrow limestone-defended terraces on the east side of the Central Divide, as for example the gorge at the south end of Adelug Cliffs and the one between Adelug and Machegit Cliffs. These features are not as prominantly developed on the west side of the divide, largely because of the narrowness and poor development of the terraces.

\section{SPRINGS}

There are several moderately large springs on Saipan. ${ }^{1}$ Most of them are in the Central Divide and issue from

1 All information on springs is abstracted from the report by A. M. Piper, 1946. 
the contact of the volcanic rocks and the overlying limestones, or from residual deposits. Of the 12 springs in this category listed by Piper (1946), 6 are on each side of the divide. The largest is Donni Spring on the eastern side of the Central Divide at an altitude of about 325 feet $\left(1190 \mathrm{E} .-2365 \mathrm{~N}\right.$.). ${ }^{2}$ According to Piper this spring has a discharge ranging from about 80,000 to about 400,000 gpd (gallons per day) and the chloride content of about $40 \mathrm{ppm}$ (parts per million). It served as the principal source of supply for the towns of Tanapag and Garapan.

The minimum discharge from the remaining 11 springs ranges from 5,000 to $40,000 \mathrm{gpd}$ with an average of about $14,000 \mathrm{gpd}$, the maximum ranges from about 10,000 to 80,000 gpd with an average of about 32,000 gpd. Many of these springs were developed by the Japanese as auxiliary sources of water supply.

The largest spring on the island, the Starch Factory spring at Tanapag (0890 E.-2701 N.) issues from beach deposits and is only about 0.3 foot above mean lower low water. This spring has a normal flow from 100,000 to 130,000 gpd and at times is said to flow in excess of $2,000,000 \mathrm{gpd}$. It has a chloride content that varies between 480 and $1,200 \mathrm{ppm}$ and the water is used only for industrial purposes.

\section{LAKWS AND SWAMPS}

Just east of Chalan Kanoa is a tract of marshland, about $7 / 8$ by $1 / 2$ mile in extent. The center contains a shallow brackish water lake, Lake Susupe, whose altitude is about 6 feet above sea level.

A smaller marsh, also brackish, lies just north of Garapan.

\section{GEOLOGY}

Saipan is the remnant of a volcanic island that has undergone erosion, submergence, and differential elevation due to faulting, and whose core of volcanic rocks is now heavily veneered with limestones ranging in age from Eocene to Recent. No physical evidence of volcanism such as cones, craters, or other topographic features due to this cause remain, and the stratigraphic evidence indicates that volcanic activity ceased early in, or possibly before, the Miocene epoch.

In these respects the geology of Saipan is in close agreement with that of the other five of the southern Mariana Islands. Igneous rocks (mostly andesitic) of early Tertiary age are exposed on Guam, Rota, and Tinian, and form the basement on which a series of

${ }^{2} \mathrm{Numbers}$ in parentheses give locations in terms of the $10,000 \mathrm{yd}$. grid on the map, 1 ete 1. limestones has been deposited. No igncous rocks are known to crop out on either Aguijan o: Farallon de Medinilla, although presumably they underlie both islands. Asano, (1939a, fig. 4) gives a correlation chart for all of the Southern Mariana Islands except Guam, showing the relative ages of the limestone strata exposed on each. This chart, with modifications by the writer, is reproduced below. The columns given by Asano for Rota and Tinian agree closely with the writer's field observations on these islands.

TABLE 1.-Distribution of limsetone units in the southern Mariana Islands.

Modified from Asano, K., Limestones of the South Sea Islands under Japanese Mandate: The Jubilee publication in commemoration of Pro'essor H. Yabe's 60th Birthdey, vol. I, p. 546, fig. 4, 1939.]

\begin{tabular}{|c|c|c|c|c|c|c|}
\hline & $\begin{array}{c}\text { Farallon } \\
\text { de Medi- } \\
\text { nills }\end{array}$ & Saipan & Tinian & Aguijan & Rota & Guam 1 \\
\hline $\begin{array}{l}\text { Plio-Pleistocene } \\
\text { Plio-Pleistocene } \\
\text { Miocene. } \\
\text { Do. }{ }^{2} \\
\text { Do. }{ }^{2} \\
\text { Eocene. }\end{array}$ & $\mathrm{Lm}_{2}$ & $\begin{array}{l}\mathrm{Lp}_{2} \\
\mathrm{Lp} \\
\mathrm{Lm} \\
\mathrm{Lo}_{2} \\
\mathrm{Lo}_{1} \\
\mathrm{Le}\end{array}$ & \begin{tabular}{c}
$\mathrm{Lp}_{2}$ \\
$\mathbf{L p} \mathrm{p}_{1}$ \\
$\mathrm{Lm}$ \\
$\mathrm{Lo} \mathrm{o}_{2}$ \\
\hdashline \\
\hdashline
\end{tabular} & $\begin{array}{r}\mathrm{Lp}_{2} \\
\hdashline-\overline{-} \\
\hdashline-\overline{-} \\
\hdashline-\overline{-}\end{array}$ & \begin{tabular}{l}
$\mathrm{Lp}_{2}$ \\
$\mathrm{Lp}_{1}$ \\
$\mathrm{Lo}_{2}$ \\
\hdashline $\mathrm{Le}^{-}$
\end{tabular} & $\begin{array}{l}\text { Present. } \\
\text { Present. } \\
\text { Present. } \\
\text { (?). }\end{array}$ \\
\hline
\end{tabular}

1. Column for Guam compiled from observations by Steams, Bridge and Piper. 2 "Oligocene" of Asano.

This table reveals that the most complete section of Tertiary limestones in the Southern Mariana Islands is exposed on Saipan. In addition to thir. Saipan, because of its good exposures, moderate size, and good road system that provides ready access to almost all parts of the island, is probably the key area in any future studies on the stratigraphy, structure and geologic history of the southern Mariana Islends.

No detailed studies of the geology of the island could be made in the time allotted and the only report available at the time of the investigation was a translation of a short paper by Tayama, evidently a talk delivered before some local group on Saipan. The map accompanying this report was on a very small scale, highly generalized, and of little value. Subsequently, translations of more detailed reports by Tayar`a (1938) and Asano (1939 a-b) became available.

Because of these limitations, the formation names in this report are used in a quotational seise, represent the names used in translations of Japanes? reports, and are not stratigraphic units established as the result of an independent survey. The work of Cloud and his associates (p. 2 this report) will undoubtedly present a much more detailed and comprehensive treatment of the stratigraphic succession. 


\section{STRATIGRAPHY}

The stratigraphic succession and age assignment as worked out by the Japanese geologists is as follows:

TABLE 2.-Columnar section for Saipan

[Columns at left and center after Asano $\underset{(1939) \text { b) }}{(1939}$ pp. 333-335), column at right by Colo

\begin{tabular}{|c|c|c|}
\hline $\begin{array}{c}\text { Limestone } \\
\text { [Asano] }\end{array}$ & $\begin{array}{l}\text { Stratification } \\
\text { (Tayama) }\end{array}$ & $\begin{array}{c}\text { Correlation } \\
\text { (Cole) }\end{array}$ \\
\hline $\begin{array}{l}\text { Younger lime- } \\
\text { stone. }\end{array}$ & $\begin{array}{l}\text { Recent limestone. } \\
\text { Raised beach deposits. } \\
\text { Raised coral limestone- } \\
\text { Reddish brown clay. }\end{array}$ & Recent or Pleistocene. \\
\hline $\mathrm{Lp}-2 \ldots \ldots$ & Mariana limestone. & \multirow{2}{*}{ Pliocene-Pleistocene. } \\
\hline $\mathrm{Lp}-1 \ldots \ldots$ & Naftan limestone. & \\
\hline $\mathrm{Lm}_{\ldots} \ldots \ldots$ & Tagpochau limestone. & $\begin{array}{l}\text { Miocene-probably } \\
\text { highe (Aquitanian), } \\
\text { or possibly low } \\
\text { (Burdigalian), } f .\end{array}$ \\
\hline Lo-2 & $\begin{array}{l}\text { Donni bed. } \\
\text { Laulau limestone. }\end{array}$ & \multirow{2}{*}{$\begin{array}{l}\text { Miocene, } e \text { (Aquita- } \\
\text { nian). }\end{array}$} \\
\hline Lo-1... & Densiny ama bed. & \\
\hline \multirow[t]{2}{*}{$\mathrm{Le}_{\ldots} \ldots \ldots \ldots$} & Matansa bed. & Eocene (upper), $b$. \\
\hline & $\begin{array}{l}\text { Basal rocks (andesite- } \\
\text { quartz trachyte). }\end{array}$ & \\
\hline
\end{tabular}

In general the older limestones (Eocene to Miocene) crop out along the flanks of the Central Divide at altitudes above $250 \mathrm{ft}$, while the younger formations (Pliocene to Recent) make up the bulk of the Terrace Platform and the lowlands and beaches bordering it. Where the Terrace Platform is absent or poorly developed, or where it is trenched by deep ravines, the older limestones may crop out at lower altitudes. Older limestones also occur on the surface of the Terrace Platform along some of the major faults.

The distribution of larger Foraminifera identified by Cole from the samples is shown by the table on page 19 .

\section{BAsAL VOLCANIC ROCKS}

The oldest rocks exposed on Saipan are a series of rhyolite flows, agglomerate, and pumice, known as the Sankakuyama rhyolite and typically developed on and around Mount Achugau (Sankakuyama) and along the south shore of Fañunchuluyan Bay. The small island, Maigo Fahang (Tsukimi), within the bay is composed of white pumice belonging to the Sankakuyama rhyolite.

In other parts of Saipan the oldest rock exposed is an augite-andesite lava, with associated beds of agglomerate tuff. This is known as the Hagman andesite from its typical development on the Hagman peninsula. It also crops out on Laulau Mountain, on Fina-sisu Ridge, at the south end of the Central Divide, and on both sides of the Central Divide to the southerst and northwest of Talofofo Ridge (Densinyama). The rhyolite is confined to a few small areas in the vicinity of Mount Achugau, and its pumiceous equivalent is exposed in the cliffs at Fañunchuluyan Bay and on Maigo Fahang Island.

The andesitic lavas, agglomerates and andesitic tuffs cover a much larger area, at least ten times the size of that in which rhyolites are exposed. Tre lavas are confined to small areas on Hagman Point, Laulau Mountain, a small area on the west side of the island just east of Tanapag, and another small area also on the west side just north of the mouth of Papau Valley. These areas comprise less than 15 percent of the area in which andesitic materials occur, pyroclastics being exposed over the remaining 85 percent.

The relationship of these two formations is uncertain but the Sankakuyama rhyolite is considered to be older by the Japanese geologists. No descriftion of these formations is given in this report but spocimens $\mathrm{S}-6, \mathrm{~S}-12$, and S-15a-f (see map), represent the Sankakuyama rhyolite, and specimens $\mathrm{S}-1, \mathrm{~S}-20$, and S-27, represent the Hagman andesite. ${ }^{3}$

\section{MATANGA ITMESTONE}

The Matansa limestone was named by Tayama (1938) from the Matansa district on the northwest slope of the Central Divide west of Kalabera Pass in the northern part of the island. He has also called it the "Camerina limestone" from the abundance of that genus at some localities. It is the oldest limestone formation on Saipan and is described as an sndesite boulder conglomerate, overlain by bedded tuffs and finally by well-stratified pink limestones. $\mathrm{Tr}$ a total thickness is not given and doubtless varies greatly from place to place, but the limestones are sajd to be 3 to 5 meters $(10-16 \mathrm{ft})$ thick.

The formation rests unconformably on the Sankakuyama rhyolite or on the Hagman andesite, and is overlain by younger igneous and sedimentary formations of various ages. Its known areal distribution is limited to five small patches, the extent of vhich is greatly exaggerated on Tayama's maps. Two of these were located and are shown in plate 1 . In the present collections, the Matansa formation is represerted by specimens from three localities, S-18, S-24, S-32. At the last named locality the limestone occurs as $k$ sulders in the Densinyama formation, a volcanic tuff 1 nlieved to overlie the Matansa limestone; a situation analogous to the occurrence of boulders of Eocene limestone in volcanic agglomerate in the Palau Islands (Cole, 1950, p. 22). The individual boulders in this collection

The specimens mentioned in this report are preserved in the U. $\Sigma$. National Museum. A duplicate set has been deposited in the Bernice P. Bishop Museum in Honolulu. 
are designated by small letters following the locality numbers.

$S-18$. - Matansa district, small quarry on the southeast side of the old road to Kalabera Pass, just northeast of the mouth of Papau Valley. (1395 E.-2965 N.) Altitude about $300 \mathrm{ft}$. Locality mentioned by Tayama.

Limestone, fragmental, fresh surfaces mottled white to orange-pink (10 R 7/4), ${ }^{4}$ the pink tones predominating and giving the whole sample a distinct red color. Texture finely granular to aphanitic, fragments colored and aphanitic, containing Foraminifera and fragments of shells. Cementing material white, finely crystalline. Fracture subconchoidal to hackly.

Fauna: Asterocyclina sp. Spiroclypeus sp.

S-24.-Achugau district, about 0.4 mile due east of Mount Achugau on the northeast slope of a main valley of the Nanasu drainage system, in a horseshoe bend on an abandoned road in a sugarcane field (1395 E.-2867 N.) Altitude about $450 \mathrm{ft}$. Excellent collecting, many large Foraminifera found on the surface, weathered free from the matrix.

Limestone, fragmental, containing numerous large Foraminifera. Color ranging from moderate reddish orange $(10 \mathrm{R} 6 / 6)$ in the more deeply tinted parts of the specimens to moderate orange-pink (5 YR 8/4) all tones seem somewhat lighter because of the white flecks which are sections of Foraminifera. Texture granular, fracture rough.

Fauna: Asterocyclina sp.

Biplanispira mirabilis (Umbgrove).

Camerina saipanensis Cole n. sp.

Discocylina sp. 1.

D. sp. 2.

Heterostegina saipanensis Cole n. sp.

Pellatispira rutteni Umbgrove.

S-32a.-Achugau district. Conglomerate in the Densinyama formation. Cut on the Talofofo Road (1207 E. -2818 N.) on west side of the Central Divide about 0.5 mile southeast of the junction with the West Coast Highway. Altitude about $200 \mathrm{ft}$.

Limestone, mottled, fresh surfaces very pale orange (10 YR 8/2), with a few irregular light brown (5 YR $6 / 4)$ mottlings. Texture very finely crystalline, compact, fracture conchoidal to subconchoidal. Weathered surfaces rough and minutely irregular, stained with white, yellowish-brown and black splotches.

Fauna: Pellatispira crassicolumnata Umbgrove.

S-32c.-Achugau district. Conglomerate in the Densinyama formation. Cut on the Talofofo Road

4 In the following descriptions all colors are given in accordance with the classification and terminology used in the Rock Color Chart, National Research Council, Washington, 1948, and the symbols in parentheses following the color name are those used on that chart.
(1203 E. -2830 N.), about 0.5 mile southeast of the junction with the West Coast Highway. Altitude about $200 \mathrm{ft}$.

Limestone, mottled, background a grayish-orange pink (10 R 8/2) with splotches and grains of darker tones of pink and brown, the deepest being about a light brown (5 YR 6/4). Texture fragmental, the fragments consisting of bits of compact limestone, limesand grains, Foraminifera and bits of other fossils. Fracture semiconchoidal to rough. Weathered surfaces rough and minutely pitted, commonly white, with irregular yellow, yellowish brown and black stains.

\section{Fauna: Pellatispira crassicolumnata Umbgrove} Fabiania saipanensis Cole n. sp.

\section{DENSINYAMA FORMATION}

The Densinyama formation was named by Tayama from Talofofo Ridge, a section of the Central Divide north of the Cross-island Highway and south of Mount Dogas, and known to the Japanese as Densinyama or Telegraph Hill from the large radio station formerly located about 0.5 mile southwest of the place where the Talofofo Road crosses the Central Diride.

The formation consists of beds of conglomerate, andesitic tuff, fuller's earth, calcareous sandstone and sandstone. The boulders within the conglomerate are derived from the Sankakuyama rhyolite, the Hagman andesite and the Matansa formation (S-32a, c), and the formation rests unconformably on the first two of these and presumably upon the third as well.

Most of the formation appears to have been deposited under marine conditions, and much of it is w'oll stratified. The presence of limestone boulders containing Eocene Foraminifera indicates that most of it is slightly younger than the Matansa formation. According to Tayama (1938) the following Foraminifera have been identified by Hanzawa and Asano from the Densinyama formation, but he does not state whether these forms came from boulders within the formation or from the tuff enclosing them, or from both.

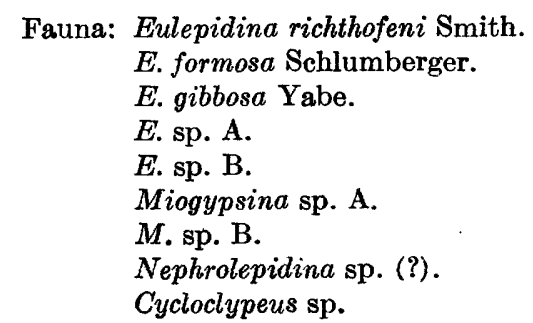

No specimens were collected from the tuffs of the Densinyama formation so no direct information regarding this fauna is available. However, on trabasis of the lists given, Cole (letter, 1951) suggests that

This fauna with Eulepidina and Miogypsina is Tertiary $e$ (Aquitanian). Although Eulepidina occurs in Tertiary $d$, 
Miogypsina is restricted to Tertiary $e$ and $f$, Asano and Tayama were not correct when they placed these beds in the Oligocene.

\section{LAULAU LIMESTONE}

The Laulau limestone was named by Tayama from exposures in the railway' cuts on the south side of Laulau Mountain northwest of the village of Laulau on the north side of Laulau (Magicienne) Bay. For the most part the Laulau limestone crops out on the terraces at the base of the Central Divide above the general level of the Terrace Platform, but it is also exposed in cliffs on the Terrace Platform along the fault line scarp running northeast from Obyan Point. There is a small patch of this formation on the summit of the Hagman peninsula and a few small exposures of it in some of the deep ravines cutting the Terrace Platform, as for example on the south side of Laulau Mountain just west of Laulau village ond on the northwest coast where the Terrace Platform is absent just west of Mount Achugau.

\section{According to Tayama the Laulau limestone is}

Of various colors, white, black, red, brown, and yellow, but [a gray limey marl] with black speckles is the most abundant type. Arenaceous limestones predominate, tuffaceous and marly limestones are common while pure limestone is comparatively rare. Though the superficial features differ from each other all types contain abundant specimens of the foraminifer Eulepidina by which it is distinguished from other limestones. (Tayama, 1938)

The Laulau limestone grades laterally into well stratified, water-laid Donni tuff.

The Laulau limestone is represented in these collections by 12 samples from 10 widely distributed localities.

$S-3$.-Bañadero district, small ballast quarry at the northeast base of Bañadero Cliff west of the coastal highway and just north of the secondary road leading southward to an abandoned hospital. (1812 E.-3319 N.) Altitude about $110 \mathrm{ft}$.

Limestone, white, $(\mathrm{N}-9)$ with occasional yellowish tints. Texture fine grained, chalky to dense. Fracture rough and hackly.

Fauna: Borelis pygmaeus Hanzawa.

Lepidocyclina (Nephrolepidina) brouweri L. Rutten. $L$. (N.) sumatrensis Brady.

Spiroclypeus tidoenganensis van der Vlerk.

S. orbitoideus H.Douvillé.

S-13.-Achugau district, summit of Mount Dogas (Asumaitok), a limestone outlier just south of Mount Achugau. (1290 E.-2815 N.) Altitude $720 \mathrm{ft}$.

Limestone, fresh surfaces pinkish gray (5 YR 8/1) to moderate orange pink (5 YR 8/4), with small flecks of white. Weathered surfaces light olive gray to olive gray (5 Y 6/1-4/1). Partly weathered but freshly broken surfaces show tones between moderate reddishorange and moderate reddish-brown (10 R 6/6-4/6).
Texture fine to moderately crystalline, most. of the white flecks appear to be Foraminifera or fragments of shells; fracture hackly.

Fauna: Borelis pygmaeus Hanzawa.

Heterostegina borneensis van der Vlerk.

Lepidocyclina (Nephrolepidina) newtoni Y'abe and Hanzawa.

L. (N.) parva Oppenoorth.

S-14.-Achugau district, summit of the Central Divide just north of Mount Achugau. (15 55 E.$2882 \mathrm{~N}$.) Altitude about $550 \mathrm{ft}$.

Limestone, fresh surfaces mottled white $(\mathrm{N}-9)$ to various shades including pinkish-gray (5 YR 8/1), moderate orange pink (10 R $7 / 4)$, to grayish orange pink (10 R 8/2). Somewhat weathered but freshly broken surfaces are grayish orange (10 YR 7/4). Natural weathered surfaces are a pale yellowish-brown to olive gray.

Texture dense, composed of Foraminifera and shell fragments in a very fine-grained ground mass. Weathered surfaces rough and pitted, fracture sub-con hoidal.

Fauna: Heterostegina borneensis van der Vlerk. Lepidocyclina (Nephrolepidina) brouweri L. Rutten. Spiroclypeus orbitoideus H. Douvillé.

S-16.-Matansa district, east side of Papau Valley at sharp bend in the valley near the end of the road and about $50 \mathrm{ft}$ above the floor of the valley. (1340 E.$2905 \mathrm{~N}$.) Altitude about $160 \mathrm{ft}$.

Limestone, fresh surfaces white to yellowish-gray (5 $\mathrm{Y} 7 / 2$ ), weathered surfaces grayish-orange (10 YR $7 / 4$ ) with shades of gray and medium-gray.

Fauna: Lepidocyclina (Nephrolepidina) brouweri L. Rutten. Miogypsinoides formosensis Yabe and Hanzawa. Spiroclypeus orbitoideus H. Douvillé.

S-17.-Matansa district, east side of Papau Valley, at sharp bend in the valley opposite the end of the road, about $40 \mathrm{ft}$ above the floor of the valley. (1339 E.$2905 \mathrm{~N}$.) Altitude about $150 \mathrm{ft}$.

Limestone, fresh surfaces grayish-orange (10 YR $7 / 4$ ), flecked with white. Weathered surfaces various shades of yellow brown with gray to black shadings. Texture, finely granular, fracture rough.

Fauna: Borelis pygmaeus Hanzawa.

?Lepidocyclina (Nephrolepidina) parva Opnenoorth.

S-25.-Laulau district, along old railroad grade on the north side of Laulau Bay in the third cut from the west and about 1 mile west of the intersection with the East Coast Highway north of Laulau village. (1040 E.-1965 N.) One of the localities mentioned by Tayama.

Marl or marly limestone. Texture soft and friable, easily crumbled by hand. Fresh surfaces mottled white to yellowish gray (5 Y 8/1) with minute black 
specks that are magnetite grains derived from the weathering of the volcanic rocks. Contains many large specimens of Lepidocyclina as much as $25 \mathrm{~mm}$ in diameter. Fracture granular.

Fauna: Heterostegina borneensis van der Vlerk. Lepidocyclina (Eulepidina) formosa Schlumberger. L. (E.) planata Oppenoorth.

L. (Nephrolepidina) parva Oppenoorth.

The sample collected by Stearns (p. 1), his number $\mathrm{SN}-39$, is said to have come "from a railroad cut on the east side of Saipan Island near Magician [Laulau] Bay." It represents the same horizon as S-25 and is probably from the same locality. It contains abundant specimens of Lepidocyclina formosa Schlumberger, and some of the specimens illustrated are from this locality.

S-26. - Laulau district, along the old railroad grade on the north side of Laulau Bay in the first cut from the west, about 1.5 miles west of the intersection with the East Coast Highway, north of Laulau village. (1022 E.-1961 N.) Altitude about $240 \mathrm{ft}$.

Limestone, mottled pinkish gray (5 YR 8/1) to moderate pink (5 $\mathrm{R} 7 / 4$ ) or possibly moderate orangepink. (10 R 7/4) Texture fragmental, the fragments generally light, the matrix darker. Fracture subconchoidal to hackly.

\section{Fauna: Borelis pygmaeus Hanzawa.}

Heterostegina borneensis van der Vlerk.

Lepidocyclina (Nephrolepidina) parva Oppenoorth.

S-30.-Tanapag district, limestone overlying andesite in quarry just east of the West Coast Highway near Tanapag (1030 E.-2760 N.) Altitude about $60 \mathrm{ft}$.

Limestone, earthy, mottled, colors ranging from pale yellowish orange (10 YR 8/6) to moderate orange-pink (5 YR 8/4). Weathered surfaces light brown (5 YR $6 / 4$. Texture fine grained, earthy, many large Foraminifera scattered throughout appearing in sections as white specks.

Fauna: Lepidocyclina (Nephrolepidina) sumatrensis Brady Operculina sp.

Spiroclypeus tidoenganensis van der Vlerk.

S-31.-Achugau district, east side of Talofofo Road just west of prominent fault west side of Talofofo (Densinyama) Ridge just north of bend 0.45 mile (airline) southeast of junction with the West Coast Highway. (1178 E.-2833 N.) Altitude $120 \mathrm{ft}$.

Limestone, soft, earthy and friable. Color ranging from grayish-orange pink (10 $\mathrm{R} 8 / 2$ ), to moderate orange-pink (5 YR 8/4) mottled with many white and black grains, the former fragments of Foraminifera, the latter presumably manganese. Texture granular, the individual granules composed of fragments of calcite crystals, limestone, fossils, and manganese pellets. Fracture rough.
Fauna: Lepidocyclina (Nephrolepidina) parva Oppenoorth. Miogypsinoides formosensis Yabe and Hanzawa. Spiroclypeus higginsi Cole.

Spiroclypeus tidoenganensus van der Vlerk.

S-34.-Conspicuous limestone quarry in the Dago Cliffs about 0.75 mile north of Isley Field and about 0.75 mile east of the Isley Entrance Road. (0824 E.$1676 \mathrm{~N}$.) Altitude about $210 \mathrm{ft}$.

S-34a.-Limestone, speckled, moderately hard. In general a moderate pink ( $5 \mathrm{R} 7 / 4$ ), with deeper spots of moderate red (5 R 5/4), many white spec ${ }^{\text {rs }}$ and a few black specks. Texture medium coarse, fragmental, many of the fragments being Foraminifere and bits of shells. Fracture rough and uneven.

Fauna: Cycloclypeus eidae Tan.

Lepidocyclina (Eulepidina) bridgei Cole n. sp.

L. (E.) gibbosa Yabe.

L. (E.) saipanensis Cole n. sp.

L. (Nephrolepidina) brouweri L. Rutten.

$L$. (N.) parva Oppenoorth.

Miogypinoides formosensis Yabe and Hanzawa.

Operculina victoriensis Chapman and l'arr.

Spiroclypeus higginsi Cole.

Strebulus saipanensis Cole, n. sp.

S-34b.-Limestone, similar to 34-a, but much lighter in color and much harder. Background grayish-pink (5 Y 8/2), with specks of deeper color, (moderate red, $5 \mathrm{R} 5 / 4$ ) and occasional specks of black.

Fauna: Austrotriilina howchini (Schlumberger).

Borelis pygmaeus Hanzawa.

Lepidocyclina (Nephrolepidina) brouwsi L. Rutten. Miogypsinoides formosensis Yabe and Hanzawa. Spiroclypeus higginsi Cole.

Victorieila plecte (Chapman).

S-34c.-Similar to S-34b, but still more compact and hard. Groundmass a moderate orange-nink $(10 \mathrm{R}$ 7/4) with many white specks most of which are fragmentary fossils and occasional dark lrownish-red specks. Texture compact and fragmental. Fracture subconchoidal to uneven.

This area was mapped as Tagpochau limestone by Tayama probably because of the color of th a limestone. Cole's studies indicate that it is of Laulau ag's.

Fauna: Lepidocyclina (Nephrolepidina) brouweri L. Rutten. Spiroclypeus higginsi Cole.

\section{DONNI TUFF}

The Donni tuff is presumably named for Donni stream along which it is well exposed. It is a brilliantly colored and well stratified formaticn consisting of beds of conglomerate, tuff, sandstone, and shale. The conglomerate layers contain limestone pebbles and boulders from the Laulau, Tagpochau and (presumably) Matansa formations, though no fragments of the last were found. The formation rasts unconformably on the Sankakuyama rhyolite, the Hagman 
andesite and tuffs of the Densinyama formation, and grades laterally into the Laulau and Tagpochau limestones. It is overlain disconformably by the Naftan and Mariana limestones.

The best exposures of the Donni tuff are on the eastern side of the Central Divide where it crops out in a narrow belt extending from the east end of Laulau Mountain on the south to Hasngot Valley on the north. Farther north it seems to be largely overlapped by the Mariana limestone but reappears in small areas in some of the valleys from Talofofo stream northward and also in small patches along the western side of the Divide. There is also a small patch of this formation on the Hagman peninsula, another along the Obyan fault scarp about 0.9 mile north of Isley Field, and a third along the Agingan fault scarp to the east of Kobler Field.

Both Tayama and Asano list a small macrofauna consisting of corals and crustaceans from the Donni tuff, but except for a statement by Tayama that Globigerina is found in marl in the upper part of the formation, there is no mention of a microfauna. No large Foraminifera were found in the samples collected, but the fine-grained tuffs, marls and sandstones contained a large assemblage of smaller forms. The following species have been identified by $M$. Ruth Todd of the Geological Survey:

TABLE 3.-Small Foraminifera from the Donni tuff

\begin{tabular}{|c|c|c|c|}
\hline & \multicolumn{3}{|c|}{ Localities 1} \\
\hline & -8 & $\mathrm{~s}-28 \mathrm{a}$ & $8-28$ \\
\hline \\
\hline \multirow{2}{*}{\multicolumn{4}{|c|}{$\begin{array}{l}\text { Cassidulina sp. } \\
\text { C. cf. subglobosa } \mathrm{H} \text {. B. Brady }\end{array}$}} \\
\hline \multirow{2}{*}{\multicolumn{3}{|c|}{ Cibicides? sp }} & \\
\hline & & & \\
\hline \multicolumn{4}{|l|}{$\begin{array}{l}\text { C. cicatricosa (Schwager) } \\
\text { Dentalina } \text { sp }_{\text {Enonides umbonatus (Reuss) }}\end{array}$} \\
\hline \multicolumn{4}{|l|}{$\begin{array}{l}\text { Eponides umbonatus (Reuss) } \\
\text { E. sp }\end{array}$} \\
\hline \multicolumn{4}{|l|}{$\begin{array}{l}\text { Globigerina n. sp. (cf. G.? kochi Boomgaart (not } \\
\text { Caudri)) }\end{array}$} \\
\hline \multicolumn{4}{|l|}{$\begin{array}{l}\text { G. sp. } \\
\text { Globigerinoides conglobata }(\mathrm{H} . \mathrm{B} \text {. Brady) }\end{array}$} \\
\hline \multicolumn{3}{|l|}{$\begin{array}{l}\text { G. sacculifera (H. B. Brady) } \\
\text { G. cuclostoma (Galloway and Wissler) }\end{array}$} & \\
\hline \multicolumn{4}{|c|}{ 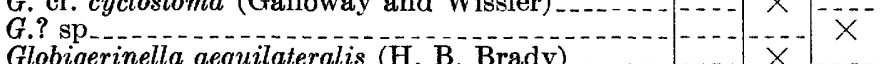 } \\
\hline \multicolumn{4}{|l|}{$\begin{array}{l}\text { Globigerinella aequilateralis (H. B. Brady) } \\
\text { Globorotalia menardii (D'Orbigny) } \\
\text { G. tumida }(\mathrm{H} . \text { B. Brady) }\end{array}$} \\
\hline G. tumida (H. B. Brady) & & & \\
\hline \multicolumn{4}{|l|}{$\begin{array}{l}\text { Orbulina universa D'Orbigny } \\
\text { O. bispherica LeRoy }\end{array}$} \\
\hline \multirow{2}{*}{\multicolumn{4}{|c|}{$\begin{array}{l}\text { P.? sp } \\
\text { Pyrgo cf. lucernula (Schwager) }\end{array}$}} \\
\hline & & x & \\
\hline \multicolumn{3}{|l|}{$P$. murrhina (Schwager) } & \\
\hline \multirow{2}{*}{\multicolumn{4}{|c|}{ Sphaeroidina sp Spaeroidinella seminulina (Schwager) }} \\
\hline & & x & \\
\hline
\end{tabular}

1 S-8. - Laulau district, intersection of old railway and the East Coast Highway north of Laulau village. (1215 E.-2010 N.) Altitude about $120 \mathrm{ft}$.

S-28. - I Hasngot district, cuts on the west side of the East Coast Highway 0.15 mile (airline) north of the intersection with the Oross-island connecting highway, and south of the crossing of Hasngot stream. (1284 E,-2503 N.) Alt
$150 \mathrm{ft}$. Sample S-28a is a fine-grained tuff, $\mathrm{S}-28 \mathrm{~b}$ a coarse-grained tuff.

\section{TAGPOCHAU LIMESTONE}

The Tagpochau limestone was named by Tayama (1908), for Mount Tagpochau, the highest peak on Saipan, which is said to be capped by limestone of this formation. It is described as a hard, compact, coralline limestone, locally conglomeratic at the base, commonly pink but ranging from deep red to white. It is said to overlie the Donni tuff unconformably, and is believed to have a similar relation to the Laulau limestone. Tayama admits that the Tagpochau limestone is difficult to distinguish from the Lauls.u and relies mainly on differences in topographic position, color, and faunas, the chief distinction according to him being the presence of Eulepidina or Spiroclypeus in the Laulau and the presence of Nephrolepidina or Miogypsina in the Tagpochau limestone. Actually, identification of the two limestones is not as simple as this would imply, and Tayama's map shows many anomalies for which no satisfactory explanation is given. Tayama divided the Tagpochau limestone into an upper and a lower zone; the lower division in g'oneral forming higher terrace levels than the upper one, with the supposedly older Laulau limestone occupring a belt between them. No discussion of the structural problems in such interpretation is given. Specimens collected by Bridge from areas mapped by Tayı ma as upper Tagpochau (S-34a-c) have been identified by Cole as Laulau, and limestone boulders from the Donni tuff that (if Tayama's contention is correct) could not be younger than Laulau, contain what Cole considers to be a Tagpochau fauna. The relation between the two formations is badly confused, and it is believed that the topographic and lithologic criteria used by Tayama were inadequate to make an effective s?paration and that the entire problem will have to await the results of a more detailed field study. According to Cole, (letter, 1951)

about all that can be said at the present time is that the LaulauTagpochau sequence is of Miocene age and that it contains at least two faunal zones, or ecological provinces, one characterized by Eulepidina and Spiroclypeus, the other by abundant individuals of the genera Miogypsina' and Miogypsinoides, the species of which have been recorded elsewhere from Tertiary "f " (Burdigalian).

The specimens containing Tagpochau faunas consist of four lots, from two widely separated localities.

$S-11$.-Bañadero district, top of the terrace forming the summit of Bañadero Cliff about 0.1 mile southeast of the summit of Pidos Kalahe (Mount Marpi). (1755 E. -3325 N.) Altitude about $825 \mathrm{ft}$.

Limestone, fresh surfaces grayish-orange-pink (10 R 8/2) with lighter and darker mottlings, weathere surfaces stained with various shades of orange and reddish brown. Texture very finely crystalline to aptanitic 
with outlines of pellets and small fossils chiefly Foraminifera showing on natural and cut surfaces. Fracture semiconchoidal to rough and irregular. Weathers to smooth rounded surfaces.

\section{Fauna: Miogypsina (Miogypsina) inflata Yabe and Hanzawa. \\ $M$. (M.) mamillata Yabe and Hanzawa. \\ Miogypsinoides formosensis Yabe and Hanzawa.}

S-33.- - Limestone boulders in a layer in the Donni tuff in small quarry in the Dago Cliffs about 0.4 mile north of locality S-34, and about 0.9 mile north of Isley Field, and 0.6 mile east of the Isley Entrance Road, (0830 E. -1730 N.). Altitude about $220 \mathrm{ft}$.

$S$-33a.-Limestone, strongly mottled, white $(\mathrm{N}-9)$ through various shades of grayish pink to moderate pink (5 $\mathrm{R} \mathrm{7/4}$ ). Texture fragmental, the individual fragments, especially the white ones, hard and very fine grained. Freshly broken surfaces show abundant natural sections of Foraminifera. Weathered surfaces soft, chalky, rough, light pinkish and yellowish gray. Fracture smooth to moderately rough.

\section{Fauna: Lepidocyclina (Nephrolepidina) verbeeki Newton and Holland. \\ Miogypsina (Miogypsina) irregularis (Michelotti). M. (M.) mamillata Yabe and Hanzawa. Miogypsinoides abunensis (Tobler). $M$. formosensis Yabe and Hanzawa. Sorites martini (Verbeek).}

S-33b.-Limestone, conglomeratic, groundmass very fine grained, earthy, very close but slightly lighter than moderate reddish orange $(10 \mathrm{R} 6 / 6)$. A few white flecks representing sections of Foraminifera. Contains pebbles and fragments of limestone up to two inches in diameter. The limestone in the pebbles is yellowishgray (5 Y 8/1) to white with black mottlings, very fine grained to aphanitic, many sections of Foraminifera and fragments of fossils. The pebbles and matrix break evenly with semi-conchoidal to conchoidal fracture. Weathered surfaces rough, chalky.

Fauna: Austrotrillina howchini (Schlumberger).

Lepidocyclina (Nephrolepidina) verbeeki Newton and Holland.

Miogypsina (Miogypsina) inflata Yabe and Hanzawa.

M. (M.) mamillata Yabe and Hanzawa.

Miogypsinoides formosensis Yabe and Hanzawa.

Sorites martini Verbeek.

S-33c.-Limestone, similar in all respects to 33a.

Fauna: Lepidocyclina (Nephrolepidina) verbeeki Newton and Holland.

Miogypsina (Miogypsina) irregularis (Michelotti). $M$. (M.) mamillata Yabe and Hanzawa.

Miogypsinoides abunensis (Tobler).

$M$. formosensis Yabe and Hanzawa.

Sorites martini (Verbeek)

\section{NAFTAN LIMESTONE}

This formation was not mentioned in tl a translation of the short paper by Tayama available at the time of the field investigations, and the rocks included in it were presumably classed with the Mariana limestone. The formation was described in Tayama's large paper (1908) as a Halimeda-bearing limestone, which in its lithologic features and general stratigraphic position resembles the Tagpochau limestone. It i* said to rest unconformably on the Laulau and Donni formations and to be overlain unconformably by the Mariana limestone. Its area of outcrop on Saipan is confined to Naftan Point and to a small area on the east side of Hagman Point. The former area was rot visited in 1946 and no collections from this unit rere made in the Hagman area. According to the faunal lists given by Tayama and Asano, the Foraminifera from the Naftan limestone are practically identics with those of the Mariana limestone and both geologists assigned both formations to the Plio-Pleistocene. There seems to be no logical reason for the separation.

\section{MARIANA LIMESTONE}

The Mariana limestone consists of white to yellowishwhite, poorly stratified, soft to hard, porc'us limestone. Much of it is coralline but locally it is a Halimeda limestone. The base of the formation is commonly marked by a conglomeratic and sandy zone filled with fragments of Acropora and locally known as the Acropora bed. The Mariana limestone is the most widely exposed limestone formation on Saipan. It is confined to the Terrace Platform and the terraces beneath it and was not found at any locality within the Central Divide. The Terrace Platform thus appears to be a constructional terrace that has been raised to its present levels as the result of a regional uplift accompanied by block faulting in comparatively recent time. The Mariana limestone is represented in the collection by four samples from four widely separated localities.

$S-4$. - Bañadero district, in field about 100 feet west of the Marpi perimeter road about 600 feet northeast of the junction of this road and the East Coast Highway. From pinnacles in a field possibly a part of the old phosphate diggings $(1870$ E. $-3320 \quad$ N. $)$. Elevation about 95 feet.

Limestone, white $(\mathrm{N}-9)$, mottled with irregular areas of grayish-orange (10 YR 7/4), and pele yellowishbrown (10 YR 6/2). Texture fragmental, the individual fragments as much as $1 \mathrm{in}$. long, white, very finely crystalline, fossiliferous; the filling betwoen the fragments colored as above. Many small cavities some of which result from the solution of fossils. others from the solution of the interstitial materisl. Fracture rough. Weathered surface rough and pitted, commonly 
stained to tints ranging between pale and dark yellowish-orange (10 YR 8/6-6/6).

Fauna: Cycloclypeus (Cycloclypeus) carpenteri Brady.

S-7.- Chacha district, from the plateau forming the summit of Hagman peninsula (1455 E.-2011 N.). Altitude about $400 \mathrm{ft}$. From an area mapped as Laulau by Tayama.

Limestone, very close to but even lighter than very pale orange (10 YR 8/2). Texture very finely crystalline to aphanitic. Freshly broken surfaces show many narrow cavities as much as $10 \mathrm{~mm}$ long from which fossils, mostly Foraminifera, have been leached. Fracture rough and uneven. Weathered surfaces grayish-white, deeply pitted by solution with many sharp points, cusps, and ridges with rounded depressions between them.

Fauna: Amphistegina sp.

Cycloclypeus (Cycloclypeus) carpenteri Brady

S-35.-Chacha district, quarry just north of the Hagman perimeter road about $600 \mathrm{ft}$ northeast of the junction with the East Coast Highway (1245 E.2010 N.). Altitude about $90 \mathrm{ft}$.

Limestone, white, with very pale yellowish mottlings, hard, very fine-grained to aphanitic, weathers to a chalklike mass. Weathered surfaces rough, irregularly stained in various shades of yellow and brown. Fracture rough. Much like sample S-7, but seemingly somewhat softer.

Fauna: ?Cycloclypeus (Cycloclypeus) carpenteri Brady.

S-37.-Chacha district, summit of the terrace on North Laulau (Rorogattan) Point, at edge of cliff near trash dump (1580 E.-2018 N.), altitude $60 \mathrm{ft}$.

Limestone, similar to specimen $\mathrm{S}-4$, grayish-orange (10 YR 7/4) to pale yellowish brown (10 YR 6/2), many small white areas round to oval (Foraminifera), others irregular. Texture very fine to aphanitic, fracture rough and uneven. Weathered surfaces light gray to medium light gray (N 7-6), rough with pits, ridges and points as in specimen $\mathrm{S}-7$.

\section{Fauna: Amphistegina sp. Heterostegina sp. Operculina sp.}

T-7.-Tinian Island, on the summit of Marpo Point on the southeastern coast at an altitude of about $280 \mathrm{ft}$. above sea level. Thin layer of limestone overlying bedded tuff with angular unconformity. Limestone identical in general appearance with that from S-35. A single small specimen of Haliotis sp. collected. Cole identifies specimens of Cycloclypeus (Cycloclypeus) carpenteri Brady from thin sections cut from this sample, and assigns it to the Mariana limestone.

$$
\text { 236155-53-2 }
$$

Ladd, (personal communication), identifies the $E^{\top} a l i$ otis as $H$. cf. $H$. tuvathaensis Ladd, supposedly from the Ndalithoni limestone of the Fiji Islands (Ladd-Foffmeister, 1945). He adds that the specimen from Tinian Island is closer to the species from the Fiji Islands than to the Recent form $H$. ovina Gmelin. It differs from the fossil form from the Fiji Islands in having a somewhat sharper angle on the body whorl and a slightly better development of the radial folds. Neither the sculpture nor any trace of the spiral threads below the keel are preserved. Additional material may prove this form to be identical with $H$. tuvathaensis. The horizon of $H$. tuvathaensis, according to Ladd, is probably Pliocene $h$ but may be as old as Miocene $g$.

\section{LMMESTONES OF UNCERTAIN AGE}

One sample (S-19) contained no identifiable fossils, another (S-36) contained a mixed fauna.

$S-19$. - Limestone, fresh surfaces very pale orrnge (10 YR 8/2). Weathered surfaces light gray tending toward light olive gray (5 Y 6/1). Texture very fine grained, with granular areas;most of the granules appear to be Foraminifera or fragments of shells, in a dense ground mass. Matansa district, small quarry on the southeast side of the old road to Kalabera Pass, just northeast of the mouth of Papau Valley and just al ove locality S-18 (1395 E.-2965 N.). Altitude about 300 feet.

No identifiable fossils were found in this sample but from its position it probably represents a bed in the Matansa limestone.

S-36.- Hagman Point, near crest at the southast tip (1460 E.- 1860 N.), altitude about 370 feet. Breccia bed in tuffs below the Mariana limestone.

Sedimentary breccia or conglomerate of rounded and angular fragments of pink and white limestone as much as $1 \mathrm{in}$. in diameter in a medium dark gray to grajishblack ground mass. Limestone fragments resernble specimens described from the Laulau and Tagpochau limestones. The ground mass is fine grained, calcareous, and heavily stained with manganese oxides.

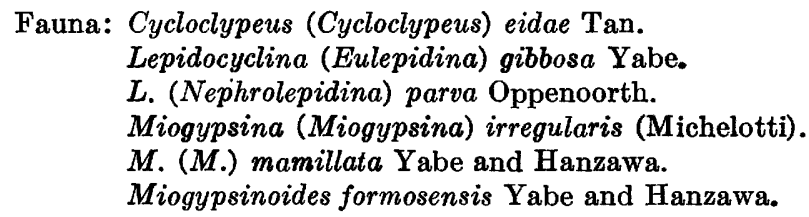

\section{RECENT DEPOSITS}

The Recent deposits consist of beach sands, locally cemented to limestone, raised beach deposits, and raised coral reefs. All of these are confined to the shore and to altitudes less than 6 to 8 feet. They are not considered in this report. 


\section{STRUCTURAL FEATURES}

Saipan is one of the 17 small islands exposed along the crest of a great submarine ridge, known as the Mariana Ridge, which rises abruptly on the west side of the Mariana Trench. This latter is one of the great deeps of the western Pacific, reaching depths of 4,500 to 5,100 fathoms about 100 miles southeast of Saipan and even greater depths southeast of Guam. The general structure of this ridge and its relation to the other major structural features of the Pacific Ocean have been thoroughly discussed by Hess (1948) and need not be repeated here.

The principal structural features of Saipan have been produced by normal faulting. Two systems of faults have been recognized; a major system in which the azimuths of the fault lines lie between $350^{\circ}$ and $35^{\circ}$, parallel to the long axis of the island, and a second, less well defined set whose azimuths lie between $70^{\circ}$ and $135^{\circ}$.

The map (pl. 1) shows the approximate location of the faults that were either observed in the field, or whose existence was deduced from a study of aerial photographs. Only the approximate locations are given, as it was impossible to trace those observed in detail in the time avaliable. Very probably there are numerous others that were not detected in the course of this brief reconnaissance.

The major faults are grouped into three well-defined more or less parallel, zones. This is best shown in the southern part of the island. The eastern zone separates the Naftan and Hagman peninsulas from the Terrace Platform to the west. The central zone divides the Terrace Platform into two levels along the Gonno and Dago Cliffs. It extends from Obyan Point into the Central Divide, passing to the west of Mount Tagpochau, and may reappear in Papau Valley at the northern end of the island. The western zone passes along the west edge of the Fina-sisu ridge and separates the Terrace Platform from the Coastal Plain to the west. It has been traced from Agingan Point into the Central Divide, but appears to be cut off or offset by a cross fault just north of Mount Tipo Pale.

The second set of faults fall into two major groups; a highly complex series in the vicinity of Mount Achugau, and a second set in the southern part of the Central Divide south of Mount Tagpochau.

The displacement along these faults may be along a single fracture, but it is commonly distributed along two or more roughly parallel fractures.

The highland forming the Naftan peninsula appears to be separated from the Terrace Platform by a series of step faults, all downthrown to the west. The easternmost fault of this group is the most strongly developed; the others though probably present are for the most part inferred from a study of aerial photos. The eastern, or main fault, is believed to cross the mouth of Laulau Bay and reappear in the fault which separates the Hagman peninsula from the Terrace Platform in the Chacha district. The displacement along this fault appears to diminish and possibly die out before reaching the sea on the north side of the Hagman peninsula. The existence of the branch fault on the south side of North Laulau Point is suggested by the topography, but its presence has not been demonstrated.

The total displacement along the faults in this group is perhaps 100 to $150 \mathrm{ft}$.

The fault at Obyan Point separates the As Gonno and I Fadang areas. It extends across the Terrace Platform at the base of the Gonno Cliffs and passes into the Central Divide through a break in the Dandan Cliffs at the mouth of the Eddot valley. In the Central Divide it appears to join with the main fault of the western series, and the two die out, or are offset by a cross fault just north of Mount Tipo Pale. A second fault in this series lies at the base of the Dago Cliffs and joins the Obyan Point fault just south of Wallace Highway. After crossing the Isley perimeter road this fault swings sharply southeast toward Naftan Point. There is a possibility that it connects with one of the postulated faults in this area, but here too further study is necessary to prove or disprove this assumption. The total displacements along these faults wl are they cross the Terrace Platform is 60 to $110 \mathrm{ft}$.

The westernmost zone of faults begins at Agingan Point, passes northeastward along the western edge of Fina-sisu Ridge and into the Central Divide where its probable location has already been described. It separates the coastal plain and swamp lands to the west from the lower levels of the Terrace. Platform and has a displacement of 60 to $100 \mathrm{ft}$.

None of these faults have been traced into the northern part of the island. However, there iv a strike fault with an azimuth of $26^{\circ}$ crossing the Talofofo Road in the edge of the hills about 0.4 mile so'xtheast of the West Coast Highway. What is thought to be this same fault was observed at one or two lonalities farther south, but the course shown on the mar is a generalization taken largely from aerial photogre,phs.

The area to the north and northeast of Mount Achugau is most complexly faulted, and the lines shown on the map are merely a generalized indication of the probable structure.

Most of the longitudinal faults belonging to the $350^{\circ}-35^{\circ}$ systems cut and displace the Mariana limestone; therefore, the latest movements slong them are of late Pleistocene or even Recent age. The evidence for the age of the $70^{\circ}-135^{\circ}$ system is less conclusive. Locally, as for example along Talofofo Road, they seem 
to be offset by faults of the major system. There is evidence that the fault east of Mount Achugau passes beneath the Mariana limestone and reaches the coast in the strong re-entrant north of Tanke Point. Both of these observations suggest that the cross faults $\left(70^{\circ}-135^{\circ}\right)$ are older than the longitudinal ones, or at least that they have not been active as recently as the longitudinal series.

It is highly probable that both fault zones were established in the early part of the Tertiary period and that they have been the sites of repeated movement throughout both the Tertiary and Quaternary periods.

A striking feature of the longitudinal system of faults is that in every one thus far observed the eastern block is upthrown in relation to the one to the west of it. In the northern group of cross faults the inner (southeastern and southwestern) blocks are upthrown, but in the southern system it is also the inner (northern and northeastern) blocks that have moved upward. That this is probably the true direction of movement is indicated by the rugged east coast, which shows evidence of repeated elevation in its steep cliffs, narrow wave-cut terraces, small bay-head beaches, and the absence of a broad reef flat. In contrast, the west coast, with its lack of conspicuous terraces, its brcad continuous beach and wide, well-developed reef flat has obviously remained relatively stable over a lcng period of time. The faults are best interpreted as tonsion faults developed along the western or back slope of the Mariana Ridge, and the general pattern and the evidence of comparatively recent movement along thom suggest that the Mariana Ridge is still growing, $\varepsilon$ nd that further uplifting may be expected along the eastern edge of the island.

There is little evidence of folding, although Tayama (1938) assumes that the main structure of the island is anticlinal and cites evidence in support of this view. There may have been very slight local folding, but the suggestion of anticlinal structure appears to be baied chiefly on the fact that the limestones and bedded volcanic rocks dip seaward on all sides of the island. This is believed to be the result of initial deposition rather than of subsequent folding. Locally the original dip of the strata and the slope of the terrace surfeces may have been increased, decreased or even rever ${ }^{\circ}$ by faulting. 
, 


\title{
CORRELATION AND SYSTEMATIC PALEONTOLOGY
}

\author{
By W. Storrs Cole
}

\section{INTRODUCTION}

The samples considered are described by Bridge in the first part of this paper and the relationships of the localities are shown on the map accompanying his stratigraphic discussion (pl. 1). The table on page 19 shows the distribution of the species found.

Certain of the samples could be crushed and the specimens recovered. These specimens not only yielded information concerning the external appearance, but also could be made into oriented thin sections for the study of the internal structures. However, many of the compact limestones could be analyzed only by random thin sections.

Although the fauna of the sample from station S-34a could be investigated by removing specimens from the matrix, five random thin sections were cut from the matrix material. The size of the actual thin section of matrix material is about 3 by $2 \mathrm{~cm}$ or $6 \mathrm{sq} \mathrm{cm}$; therefore, approximately $30 \mathrm{sq} \mathrm{cm}$ of material could be examined for random foraminiferal thin sections.

From these thin sections, in which Foraminifera are so abundant that one specimen virtually touches another, it is easy to recognize the genera Cycloclypeus, Lepidocyclina, Operculina and Streblus. Moreover, it is possible to decide that three species of Lepidocyclina were present.

In attempting specific determinations from these random thin sections, it is found that if the species is not already known, it is impossible to make such determinations. The following satisfactory sections were obtained:

Lepidocyclina (Eulepidina)! bridgei-1 oblique equatorial and 1 oblique vertical.

Lepidocyclina (Eulepidina) saipanensis-1 centered vertical.

Lepidocyclina (Nephrolepidina) parva-1 vertical, not centered.

Streblus saipanensis-1 median.

The specimens of Operculina appear as off-center transverse sections, and the same is true of the specimens of Cycloclypeus except for one oblique horizontal section that shows some of the equatorial chambers but not the embryonic or periembryonic chambers.

Yet, by crushing the matrix material and recovering specimens which could be made into oriented thin sections, ten species were satisfactorily identified.

This analysis should be kept in mind in the interpretation of the information given in this report as it explains, in part, the dangers to be encountered in interpreting and evaluating the faunas from the varic's stations.

\section{STRATIGRAPHY}

There are three, possibly four, ages represented in the present collection from Saipan. Many of the samples contain species that are known from otl ar localities in the East Indies and adjacent areas. The ages represent the Eocene, Tertiary "b"; the early Miocene or Aquitanian, Tertiary "e"; possibly the early middle Miocene or Burdigalian, Tertiary "f"; and Pliocene-Pleistocene.

In a brief discussion of Saipan, Asano (1939a), states that the limestones of Saipan are divisible into six groups which he designates $\mathrm{Le}, \mathrm{Lo}_{1}, \mathrm{Lo}_{2}, \mathrm{Lm}, \mathrm{Lp}_{1}$ and $\mathrm{Lp}_{2}$. (See table on p. 6.) Of these the present collection contains representatives of $\mathrm{Le}, \mathrm{Lo}_{2}, \mathrm{Lm}$ and $\mathrm{Lp}_{2}$.

Tayama (1938) has given these various limestones names as follows: $\mathrm{Le}=$ Matansa beds; $\mathrm{Lo}_{1}=$ Densinyama beds $; \mathrm{Lo}_{2}=$ Laulau-limestone $; \mathrm{Lm}=$ Tagpochau limestone; $\mathrm{Lp}_{1}=$ Naftan limestone; $\mathrm{Lp}_{2}=$ Mariana limestone. (See table on p. 7.)

The samples from stations S-18, S-24, S-32a and S-32c are the only ones received that represent the Matansa formation (Eocene, Tertiary "b"). Numorous samples represent the Laulau limestone (Miocene, Aquitanian, Tertiary "e"), of which the samples from stations $\mathrm{S}-25, \mathrm{~S}-30$ and $\mathrm{S}-34 \mathrm{a}$ are the best because the specimens could be separated from the matrix. However, various species could be recognized in random thin sections from samples from stations $\mathrm{S}-3, \mathrm{~S}-13$, S-14, S-16, S-17, S-25, S-26, S-30, S-31, S-34a, S-34b and S-34c, all of which are believed to represent the Laulau limestone. The Tagpochau limestone is represented by four samples: S-11, S-33a, S-33bc and S-33c. The Mariana limestone represented by four samples, $\mathrm{S}-4, \mathrm{~S}-7, \mathrm{~S}-35$, and $\mathrm{T}-7$, is Pliocene-Pleistocene in age.

Asano (1939a, p. 549) states that the Densinyama beds are apparently unconformably overlain by the Laulau limestone, but the faunas of the beds are similar.

\section{ANALYSIS OF THE FAUNAS}

\section{FOCENE}

The best-developed fauna of this age occurs at station S-24, where three species are dominant: Biplanispira 
mirabilis (Umbgrove), Pellatispira rutteni Umbgrove and Camerina saipanensis Cole, n. sp. Two species of Discocyclina and one or more species of Asterocyclina are present, but the preparations were of such nature that specific determinations are impossible. Photomicrographs of $B$. mirabilis and $P$. rutten $i$ were sent to Dr. Umbgrove who kindly replied that he agreed with the identifications (personal communication, dated March 28, 1947).

The thin sections from station $\mathrm{S}-18$ contain few larger Foraminifera, and these could not be specifically identified. However, there are several tangential sections of discocyclinids, two of which appear to belong to the genus Asterocyclina. There is one tangential transverse section of a Spiroclypeus (pl. 14, fig. 7) that superficially resembles $S$. vermicularis Tan $(1937$, p. 187).

Although the evidence is slight, the presence of the discocyclinids is proof that the sample from this station is of Eocene age. However, the horizon is different from that represented by the sample from S-24.

From stations S-32a and 32c, the random thin sections contain a Pellatispira referred to $P$. crassicolumnata Umbgrove, and a species of Fabiania which is given a new specific name. These samples are of Eocene age, but it is not possible to demonstrate their relationship to the other Eocene samples.

\section{MIOCENE}

The Laulau limestone contains a well-developed and well-preserved fauna. Several stratigraphic zones are present, or there is a facies differentiation. At station S-25 Lepidocyclina (Eulepidina) formosa Schlumberger is abundant, but at station S-30 there is virtually a pure concentrate of Spiroclypeus tidoenganensis van der Vlerk. The sample from station S-34a contains fairly abundant individuals of Cycloclypeus (Cycloclypeus) eidae Tan, a species which occurs only at this station and at station S-36.

The fauna from the Laulau limestone has been reported from numerous localities elsewhere in the eastern Pacific, and as it is a very well developed and easily recognizable fauna, a review of certain occurrences is pertinent to the present discussion.

From a limestone at the northern foot of Pasir Pabeasan, lying west of the village of Tagogapoe (Tagogapu), Java, Hanzawa (1930) reports the following larger Foraminifera, most of which occur also in Saipan. The designations given these species in the present report are indicated. Lepidocyclina (Eulepidina) richtho- feni (W. D. Smith)=microspheric form of $L$. (E.) formosa Schlumberger, $L$. (E.) formosa Schlumberger, $L$. (E.) planata Oppenoorth, L. (Nephrolepidina) melanesiana Hanzawa $=L .(N$.$) parva Opp noorth, L .(N$. douvillei Yabe and Hanzawa=microspheric form of $L$. (N.) parva Oppenoorth, $L$. (N.) ferreroi Provale $=L$. (N.) brouweri, Sporadotrema cylindricum. (Carter) $=$ Victoriella plecte (Chapman), Borelis pygmaeus Hanzawa, Heterostegina borneensis van der Vlerk.

Miss Crespin (1938, pp. 9-12, pl. $\tilde{\iota}$, figs. 1-9) describes a lower Miocene fauna from the Ok Ti river in Papua with the following species: Neoalveolina pygmaea (Hanzawa $)=$ Borelis pygmaeus Hanzawa, Heterostegina borneensis van der Vlerk, and Lepidocyclina (Eulepidina) murrayana Jones and Chapman $=L$. (E.) formosa Schlumberger.

The samples from stations S-33a, S-33bc and S-33c contain Lepidocyclina (Nephrolepidina) verbeeki (Newton and Holland). There are no specimens of the genus Spiroclypeus, but numerous individuals of the genera Miogypsinoides and Miogypsina are present. Only the last two occur in samples from station S-11.

The fauna from these samples resembles those described by Yabe and Hanzawa (1930) from Formosa in which such species as Lepidocyclina (Nephrolepidina) verbeeki, Miogypsina inflata and Miogy'psinoides formosensis occur. The age assigned to there rocks in Formosa is Burdigalian.

The composite fauna of the Laulau and Tagpochau limestones, and the stations at which the species occur are shown in table 4, on page 19.

The genus Spiroclypeus occurs at stations S-3, S-14, S-16, S-30, S-31, S-34a, S-34b, and S-34c. The subgenus Eulepidina occurs at stations S-25, and S-34a. Of the stations assigned to the Laulau limestone, only stations S-13, S-17, and S-26 have neither Spiroclypeus nor Eulepidina.

Species common to the Ifaulau and Tagpochau limestones are: Austrotrillina howchini, and Miogypsinoides formosensis.

Glaessner (1943) in his excellent article on stratigraphic problems in the Indo-Pacific region indicates that Eulepidina, Spiroclypeus and Borslis pygmaeus do not extend into the Burdigalian, and that Katacycloclypeus is the only genus confined to the Burdigalian.

Many species, such as $L$. (N.) verbe $k i$, are reported from both the Aquitanian = " $e$ " and Burdigalian = " $f_{1} "$. It is apparent from an analysis of the fauna of the 


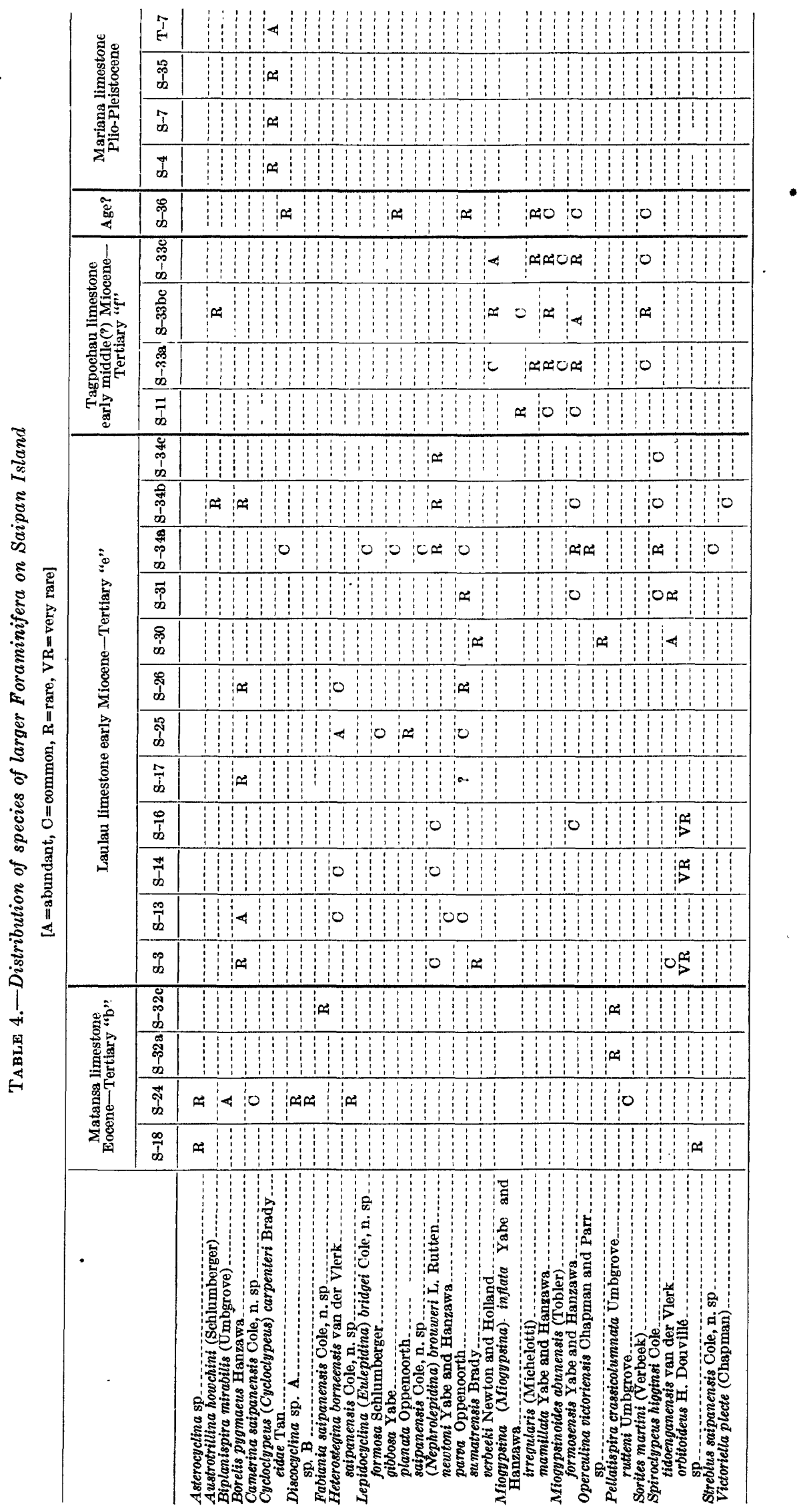


four samples, S-11, S-33a, S-33bc, S-33c from the Tagpochau limestone that the faunal development is not typical Burdigalian, such as Rembangian but neither does it show typical Aquitanian species.

Austrotrillina howchini (Schlumberger), previously considered typical of stage "e," is now known to occur in the Burdigalian.

The general aspect of the fauna from these samples suggests the Aquitanian rather than the Burdigalian, but final decision must rest upon a more complete stratigraphic and paleontologic investigations in other areas of the Indo-Pacific region.

However, an Aquitanian age assignment to the samples from station $\mathrm{S}-33$ is strengthened by the occurrence on Guam of Miogypsinoides formosensis in association with Sprroclypeus (Cole, 1939), a genus which it is assumed does not extend beyond the " $e$ " stage.

The sample from station S-36 represents a conglomerate of limestone pebbles. These pebbles carry larger Foraminifera, some of which suggest Laulau limestone and others the Tagpochau limestone. This sample with the mixed fauna may be Tagpochau limestone or younger.

\section{PLIOCENE-PLEISTOCENE}

Material from stations S-4, S-7, and S-35 contains a few vertical sections of specimens identified as Cycloclypeus (Cycloclypeus) carpenteri Brady. There are also many random sections of a rather large species of Amphistegina in the thin sections from S-7.

The thin sections from station S-37 have specimens of Amphistegina, Heterostegina and Operculina, none of which can be specifically identified. These sections are not described or illustrated, but there is little doubt that this sample comes from the Plio-Pleistocene beds.

Of the samples submitted, only that from station S-19 was without diagnostic Foraminifera.

\section{SYSTEMATIC DESCRIPTIONS \\ Order FORAMINIFERA \\ Family MILIOLIDAE \\ Genus AUSTrotrillina Parr, 1942}

Austrotrillina howchini (Schlumberger)

Plate 14, figure 12

1893. Trillina howchina Schlumberger, Bull. Soc. Geol. France, ser. 3, vol. 21, pp. 119, 120, pl. 3, fig. 6, text figs. 1,2 .

1942. Austrotrillina howchini (Schlumberger). Parr, Mining and Geol. Jour., Mines Dept., Australia, vol. 2, p. 361, text figs. 1-3.
Two random sections that show features ascribed to this well-known species were discovered in the thin sections from samples from stations S-33bc and S-34b.

Hanzawa (1940, p. 793) states that this species is found only in the Aquitanian stage in the western Pacific. Crespin (1943, p. 66), however, reports

it has been shown that Austrotrillina howchini, previously considered typical of "e" stage, has its typ? locality in the Lepidocyclina beds at Hamilton which are Ufner Middle Miocene in age.

Glaessner (1943, chart) gives the rang 3 of the genus Austrotrillina as Chattian, Aquitanian and Burdigalian, that is " $\mathrm{e}$ " and " $\mathrm{f}_{1-2}$ ".

\section{Family CAMERINIDAE \\ Genus CAMERIN A Brugière, $17: 32$ \\ Camerina saipanensis Cole, n. $\Sigma$.}

Plate 2, figures 7-19

Test evenly biconvex, thickest at center, thence sloping regularly to the bluntly rounded periphery; surface without ornamentation, although some specimens reveal faint traces of sutures when moistened. These sutures are straight and radial, but if the surface of the test is abraded slightly, the sutures toward the periphery are observed to bifurcate and become slightly meandrine.

Measurements of transverse secticns

\begin{tabular}{|c|c|c|c|c|c|}
\hline & 1 & 2 & 3 & 4 & 5 \\
\hline $\begin{array}{l}\text { Height (mm) } \\
\text { Thickness (mm) } \\
\text { Diameter of initial chamber }(\mu) \\
\text { Diameter of second chamber }(\mu) \\
\text { Spiral laminae on each side of median } \\
\text { plane (no.) }\end{array}$ & $\begin{array}{l}3.2 \\
1.8 \\
160\end{array}$ & $\begin{array}{r}3.8 \\
1.88 \\
120 \times 140\end{array}$ & $\begin{array}{r}3.4 \\
1.7 \\
180 \vee 140 \\
14) \times 80\end{array}$ & $\begin{array}{r}2.8+ \\
1.4 \\
140 \times 120 \\
120 \times 60\end{array}$ & $\begin{array}{r}2.6 \\
0.96 \\
\hdashline-1\end{array}$ \\
\hline
\end{tabular}

Measurements of median sectiors

\begin{tabular}{|c|c|c|c|c|c|}
\hline & 1 & 2 & 3 & 4 & 5 \\
\hline $\begin{array}{l}\text { Height (mm) } \\
\text { Width (mm) } \\
\text { Diameter of initial chamber }(\mu) \\
\text { Diameter of second chamber }(\mu) \\
\text { Whorls }(\text { no.) } \\
\text { Chambers m final volution (no.). }\end{array}$ & $\begin{array}{r}3.6 \\
3.4 \\
160 \\
160 \times 80 \\
5 \\
23\end{array}$ & $\begin{array}{r}3.4 \\
3.44 \\
200 \times 140 \\
180 \times 80 \\
5 \\
28\end{array}$ & $\begin{array}{r}3.6 \\
3.6 \\
140 \times 120 \\
120>50 \\
518 \\
24\end{array}$ & $\begin{array}{r}3.16 \\
3.0 \\
140 \\
120 \times 60 \\
5 \\
23\end{array}$ & $\begin{array}{r}2.34 \\
2.0 \\
140 \times 120 \\
140 \times 80 \\
434 \\
20\end{array}$ \\
\hline
\end{tabular}

The chamber walls are nearly straight and radial, except near their distal ends where they recurve sharply. Chamber walls are mallet-shaped at their proximal ends, from which point they taper very gradually to the distal ends which are very thin.

Locality: Station S-24, common. 
Type material: Holotype (uncut specimen); paratypes, 5 transverse sections and 5 median sections: U.S.N.M. 560271a-k.

This species belongs to the same group as $C$. pengaronensis (Verbeek). There is considerable similarity in the shape of the chambers as viewed in median sections. C. pengaronensis is slightly larger $(6-9 \mathrm{~mm}$ in diameter), and the slope from the umbo to the periphery is straighter, producing a biconical rather than a lenticular shape in transverse section.

\section{Genus OPERCULINA d'Orbigny, 1826}

Operculina victoriensis Chapman and Parr

Plate 5, figures 1-7

1938. Operculina victoriensis Chapman and Parr, Proc. Roy. Soc. Victoria, vol. 50, pp. 284-287, pl. 16, figs. 3-8, text-fig. 2.

Test small, compressed, with a small, eccentrically situated umbo and a wide flaring margin. Small specimens have a height of $2.4 \mathrm{~mm}$ and a width of $1.8 \mathrm{~mm}$; large specimens have a height of $3.8 \mathrm{~mm}$ and a width of $2.8 \mathrm{~mm}$; the thickness through the umbo is about 0.5 $\mathrm{mm}$ and through the flange is $0.3 \mathrm{~mm}$. The sutures may be flush with the surface of the test or very slightly raised. On the umbonal area and to a lesser extent on the flange there are small very slightly raised pustules.

The median sections show that the test is composed of $2 \frac{1}{4}$ to $3 \frac{11}{4}$ whorls, with 14 to 18 chambers in the final volution. The initial chamber is nearly circular with an internal diameter of from 60 to $100 \mu$. The second chamber is reniform. The chamber walls are evenly and gently curved until near their distal ends where they are strongly recurved.

Transverse sections show an axial plug with a surface diameter of about $200 \mu$. Several small pillarlike structures with a surface diameter of about $40 \mu$ are present. These extend from the surface about halfway to the median plane.

Locality: Station S-34a, rare.

These specimens have been compared with specimens from Australia from the Upper Quarry at Batesford which were sent to me by the late W. J. Parr. It is obvious that the specimens from Saipan are well within the specific range defined by Chapman and Parr.

\section{Operculina sp.}

Plate 4, figure 15

This species is represented by one accidental median section. The specimen has a height of $1.58 \mathrm{~mm}$ and a width of $1.1 \mathrm{~mm}$. There are $31 / 2$ volutions with 19 chambers in the final volution. The initial chambers are bilocular; the first two chambers have internal diameters of $30 \times 40 \mu$ and $20 \times 40 \mu$ respectively. The chamber walls are nearly radial.

Locality: Station S-30, rare.
As no traverse section to match this median section was found in the preparations, specific identification is impossible. The specimen is illustrated for record and future reference.

\section{Genus PELLATISPIRA Boussac, 1906 \\ Pellatispira crassicolumnata Umbgrove}

Plate 15, figures 3-7

1928. Pellatispira crassicolumnata Umbgrove, Nederlandsche Akad. Wetens. Meded., no. 10, pp. 66-67 (24-25), figs. 75-80.

This species is known in the present collection orly from $\mathrm{S}-32 \mathrm{a}$ and $\mathrm{S}-32 \mathrm{c}$ and from accidental sections none of which are centered. Brief descriptions of certain of these sections follow:

The transverse section (pl. 15, fig. 5) has a diameter of $2.9 \mathrm{~mm}$ of which $0.8 \mathrm{~mm}$ at one end and $0.3 \mathrm{~mm}$ at the other represents a thin keel whose thickness ranges from $0.16 \mathrm{~mm}$ at the outer edge to $0.26 \mathrm{~mm}$ at the inner. The transverse diameter of the main portion of the section is $0.52 \mathrm{~mm}$.

The equatorial chambers have a height of $0.26 \mathrm{~mm}$ and length of 0.16 to $0.22 \mathrm{~mm}$. The wall above and below the equatorial chambers is composed of inwardtapering pillars with vertical canals between them. The pillars form definite papillae that extend about 80 to $100 \mu$ above the general surface of the test. The surfece diameter of these papillae is 80 to $140 \mu$.

The walls of the keel are composed of pillars 20 to $40 \mu$ in diameter, giving it a fringed appearance.

The transverse section (pl. 15, fig. 6) is more nearly centered than the other two. Its diameter is $3.6 \mathrm{~mm}$, of which $0.54 \mathrm{~mm}$ is a keel that is present on one side only. The thickness of this section is $1.6 \mathrm{~mm}$. The walls over and under the equatorial layer are composed of a series of vertical canals interspaced between clear shell material. Large papillae project above the surfece of the walls. These papillae have a surface diameter of about $200 \mu$ at the point of their juncture with the surface of the test. Below this point they taper inwardly toward the equatorial layer, and above this point they become bluntly rounded. The papillae may project as much as $200 \mu$ above the general surface of the test.

An oblique equatorial section (pl. 15, fig. 7) shows the equatorial chambers in plan view. These chambers have internal diameters of about $280 \times 440 \mu$.

Locality: Station S-32, rare.

Umbgrove (1928, pp. 24-25, figs. 75-80) described this species and gave six illustrations of accidental sections to demonstrate the features. Later (1938, pp. 8289), in describing Biplanispira absurda, he stated trat certain specimens that he had included in $P$. crassicolumnata in 1928 should be transferred to $B$. absurda. $\mathrm{He}$ particularly mentions figure 79 of the 1928 article 
and states that probably the specimens represented by figures 76 and 80 of that article should be transferred also.

Detailed study of the illustrations indicates that Umbgrove was correct in 1928 in assigning all the specimens illustrated to $P$. crassicolumnata.

\section{Pellatispira rutteni Umbgrove \\ Plate 6, figures 1-8}

1928. Pellatispira rutteni Umbgrove, Nederlandsche Akad. Wetens. Meded., no. 10, pp. 20-21, figs. 57-61.

1932. Pellatispira rutteni Umbgrove. Whipple, Bernice $\mathbf{P}$. Bishop Mus., Bull. 96, p. 81, pl. 21, fig. 6 .

1947. Pellatispira reticularis Hanzawa, Japanese Jour. Geology and Geography, vol. 20, pp. 59, 60, pl. 14, figs. 1-3, pl. 15, fig. 1.

1950. Pellatispira rutteni Umbgrove. Cole, U. S. Geol. Survey Prof. Paper 221-B, p. 24, pl. 5, figs. 1, 2.

Test with an inflated central area that is demarcated sharply from the surrounding rim; diameter 3.2-3.9 $\mathrm{mm}$; thickness $1.22-1.96 \mathrm{~mm}$; inflated central portion with a diameter of 1.2 to $2 \mathrm{~mm}$. The inflated central portion has small papillae between which are polygonal pits. In some specimens papillae occur also on the rim; in others the rim appears to be smooth.

Measurements of vertical sections

\begin{tabular}{|c|c|c|c|c|}
\hline & 1 & 2 & 3 & 4 \\
\hline $\begin{array}{l}\text { Diameter (mm) } \\
\text { Diameter of central area (mm) } \\
\text { Thickmess at center (mm) } \\
\text { Diameter of initial chamber }(\mu) \\
\text { Diameter of second chamber }(\mu) \\
\text { Diameter of pillars in central area }(\mu) \\
\text { Thickness of rim }(\mathrm{mm})\end{array}$ & $\begin{array}{r}3.84 \\
2.0 \\
1.83 \\
260 \times 300 \\
160 \times 360 \\
180-600 \\
0.6\end{array}$ & $\begin{array}{r}3.74 \\
1.4 \\
1.3 \\
\text { Indistinct } \\
\text { Indistinct } \\
200-280 \\
0.7-0.8\end{array}$ & $\begin{array}{r}2.8+ \\
1.9 \\
1.2 \\
100 \times 120 \\
100 \times 90 \\
160 \div 200 \\
0.4\end{array}$ & $\begin{array}{r}3.1+ \\
2.3 \\
1.96 \\
220 \times 120 \\
220 \times 180 \\
160=220 \\
\text { Broken }\end{array}$ \\
\hline
\end{tabular}

Measurements of equatorial sections

\begin{tabular}{|c|c|c|c|c|}
\hline & 1 & 2 & 3 & 4 \\
\hline $\begin{array}{l}\text { Diameter (mm) } \\
\text { Diameter of initial chamber }(\mu) \\
\text { Diameter of second chamber }(\mu) \\
\text { Volutions (no.) } \\
\text { Chambers in a volution }(\mathrm{no} .) \\
\text { First volution. } \\
\text { Second volution. } \\
\text { Third volution. }\end{array}$ & $\begin{array}{r}3.4 \\
200 \\
180 \times 220 \\
3+ \\
10 \\
20 \\
29\end{array}$ & $\begin{array}{r}3.6 \\
290 \\
320 \times 200 \\
3+ \\
10 \\
21 \\
\text { Indistinct }\end{array}$ & $\begin{array}{r}4.6 \\
240 \times 220 \\
280 \times 160 \\
3+ \\
12 \\
22 \\
\text { Indistinct }\end{array}$ & $\begin{array}{r}3.0 \\
220 \\
220 \times 140 \\
212 \\
13 \\
19 \\
\text { Indistinct }\end{array}$ \\
\hline
\end{tabular}

The revolving wall between the chambers as seen in median sections increases in width toward the periphery of the test. This wall is composed of spicules whose long axes lie in the median plane. These spicules are about $20 \mu$ thick, and composed of clear shell material. They are separated by bands of darker material about $20 \mu$ wide, resulting in a striated appearance of the revolving wall. The roofs and floors of the chambers are perforated by many minute pores (pl. 6, fig. 7).

Vertical sections show large porelike openings between the pillars. In some sections these appear to communicate with the median layer, in others there appears to be a block of shell material at the bottom of the pore preventing communication with the equatorial layer.

Locality: Station S-24, common.

Discussion.-This species is characterized in vertical section by large porelike openings between pillars. The pillars have rather sharp points on their distal ends. These features are well shown in figure $\mathbf{5 7}$ accompanying Rutten's description of this species. A specimen from Saipan shows these same features (pl. 6, fig. 3).

The horizontal section shows a very large initial chamber. Rutten states that the type specimens have initial chambers $325-450 \mu$ in diameter. The specimens from Eau (Eua), Tonga assigned to this species by Whipple have initial chambers about $300 \mu$ in diameter. The initial chambers of the Saipan specimens are slightly smaller, about $200-300 \mu$ in dirmeter.

In total diameter and thickness through the center, the specimens from Saipan are smaller than either of those described by Rutten or Whipple. The specimens from Eau (Eua), Tonga are 5-6 $\mathrm{mm}$ in diameter and 3 $\mathrm{mm}$ thick, and Rutten states this species reaches a diameter of $8 \mathrm{~mm}$ and a thickness of $2 \mathrm{~m} \mathrm{~m}$. The largest specimen from Saipan has a diameter of $4.6 \mathrm{~mm}$, and the thickest one has a thickness of $1.96 \mathrm{mr}$.

However, the general internal arranrement and features seem to be such that the specimens from Saipan should be referred to this species. It is of interest to note that $P$. rutteni was found by Umbrrove in association with Biplanispira mirabilis in Borneo.

\section{Genus BIPLANISPIRA Umbgrove, 1937 \\ Biplanispira mirabilis (Umbgrove) \\ Plate 6, figures 9-19}

1936. Heterospira mirabilis Umbgrove, Leidsche Geol. Meded., vol. 8 pp. 155-159, 1pl., figs. 1-11.

1937. Heterospira, preoccupied, changed to Biplanispira, ibid., vol. 8, p. 309.

1938. Biplanispira mirabilis (Umbgrove). Crespin, Commonwealth of Australia, Pal. Bull., no. 3, p. 6, pl. 2, figs. 9-18.

Test biconvex to flat lenticular with a bluntly rounded periphery; diameter $2.6-4.2 \mathrm{~mm}$; thickness $1.0-1.5 \mathrm{~mm}$. Some of the flat lenticular individuals have a shallow, troughlike depression that crosses the surface of the test. The test is ornamented by numerous, round, small, white, slightly projecting papillae evenly scattered over the surface. Water-worn specimens appear smooth, but moistening the surface of the test reveals the papillae.

The vertical sections are the most. characteristic. On either side of the median layer occur the chambers of the secondary coils. These secondary chambers are not developed in the central area of the test, but toward 
the periphery they are clearly visible (pl. 6 , fig. 13, 14). In the central area the pillars extend inward to the median layer, but in the peripheral zones, where the secondary chambers are developed, the pillars penetrate only to the distal side of the secondary chambers. In some vertical thin sections each secondary chamber apparently has radiating from its roof one of the main pillars (pl. 6, fig. 13).

\section{Measurements of vertical sections}

\begin{tabular}{|c|c|c|c|c|c|}
\hline & 1 & 2 & 3 & 4 & 5 \\
\hline $\begin{array}{l}\text { Diameter }(\mathrm{mm}) \\
\text { Thickness }(\mathrm{mm}) \\
\text { Diameter of initial chamber }(\mu) \\
\text { Diameter of second chamber }(\mu) \\
\text { Surface diameter of pillars }(\mu)\end{array}$ & $\begin{array}{r}3.64 \\
1.0 \\
200 \times 240 \\
120 \times 240 \\
60-180 \\
\end{array}$ & $\begin{array}{r}2.9 \\
1.0 \\
160 \\
80 \times 140 \\
100-160\end{array}$ & $\begin{array}{r}3.9 \\
1.1 \\
180 \\
100 \times 160 \\
40-200\end{array}$ & $\begin{array}{r}4.16 \\
1.5 \\
150 \times 160 \\
100 \times 160 \\
160-220\end{array}$ & $\begin{array}{r}3.7 \\
1.3 \\
140 \times 180 \\
100 \times 200 \\
40-180\end{array}$ \\
\hline
\end{tabular}

The pillars are of two types: large ones that are thickest just below the surface of the test and taper outwards and inwards from this point, and numerous small thin pillars that occur between the larger ones. Some small pillars bifurcate before reaching the surface. Between the large and small pillars tubelike pores extend from the surface of the test to the median layer.

Measurements of median sections

\begin{tabular}{|c|c|c|c|c|}
\hline & 1 & 2 & 2 & 4 \\
\hline $\begin{array}{l}\text { Diameter (mm) } \\
\text { Diameter of initial chamber }(\mu) \\
\text { Diameter of second chamber }(\mu)\end{array}$ & $\begin{array}{r}2.6 \\
2220 \\
220 \times 120\end{array}$ & $\begin{array}{r}3.86 \\
160 \\
160 \times 140\end{array}$ & $\begin{array}{r}2.9 \\
140 \\
140 \times 100\end{array}$ & $\begin{array}{r}2.9 \\
160 \\
240 \times 140\end{array}$ \\
\hline
\end{tabular}

The initial chamber of the embryonic apparatus is spherical, and the second one subspherical. A definite coil is observed in the central area beyond which the primary coil is obscured or concealed by the secondary coils, which lie above and below the primary coil-but many of these are so situated that they appear in the median section.

Parts of the median sections not occupied by primary or secondary chambers have a striated appearance due to light and dark elongate areas that radiate from the center toward the periphery of the test in the median zone.

A thin section parallel to, but above the median zone shows numerous pillars with diameters of $140-160 \mu$. Between the pillars are numerous small, circular pores with diameters of about $40-60 \mu$.

Locality: Station S-24, abundant.

Discussion.-The original description of this genus and species was accompanied only by drawings. It is regretted that photomicrographs were not used to supplement the drawings, excellent as they are. However, the specimens from Saipan seem to have the same structures and proportions as the specimens described by Umbgrove.
Miss Crespin reports this species from the Chimbu limestone of New Guinea where it is associated with fragments of Pellatispira, Lacazina wichmanni Schlumberger, miliolids and abundant Lithothamnium.

Genus HeTERostegina d'Orbigny, 1826

Heterostegina borneensis van der Vlerk

Plate 2, figures 1-3, 5; plate 4, figures 16-18

1929. Heterostegina borneensis van der Vlerk, Nederlands?he Akad. Wetens. Meded., no. 9, p. 16, figs. 6a-c, 25a $-\mathrm{b}$. 1930. Heterostegina borneensis van der Vlerk. Hanzawa, Tohoku Imp. Univ., Sci. Rept., ser. 2 (Geol.), vol. 14, p. 95, pl. 26 , figs. 11,$19 ;$ pl. 27, figs. 4-8.

1938. Heterostegina borneensis van der Vlerk. Crespin, Commonwealth of Australia, Pal. Bull. no. 3, p. 10, pl. 3, figs. 6-9.

Several matrix-free specimens of $H$. borneensis (including one large and several small individuals) wrare found.

In the small specimens the test is thin, fragile, and ornamented by the sutures of the chambers and chamberlets. Diameter, $2.3 \mathrm{~mm}$; thickness at umbo, $0.56 \mathrm{~mm}$; thickness of flange, $0.2 \mathrm{~mm}$.

The initial chamber, which has diameters of $140 \times 120$ $\mu$ is slightly embraced by the second chamber, which has diameters of $80 \times 180 \mu$. The first chamber af er the embryonic chambers is undivided, the second contains two chamberlets. Peripheral chamberlets have radial diameters of about $160-200 \mu$ and tangential diameters of about $60-120 \mu$.

The large specimen has a height of $4.8 \mathrm{~mm}$ and a width of $3.7 \mathrm{~mm}$. The initial chamber has diameters of $100 \times 120 \mu$; the second chamber has diameters of $60 \times 180 \mu$. There is one undivided chamber before the chambers are divided into chamberlets. Peripheral chamberlets have radial diameters of $120-260 \mu$ and tangential diameters of $80-120 \mu$.

Locality: Station S-25, common.

Numerous random sections of this species occur in samples from stations $\mathrm{S}-13$, and it is less abundant in samples from stations S-14 and S-26.

Reexamination of samples from locality $D-7$ in Guam (Cole, 1939, p. 183-189) yielded several specimens that sectioning revealed to be $H$. borneensis, a form not found in the previous study. These specimens are associated with Lepidocyclina (Nephrolepidir $x$ ) parva.

Heterostegina saipanensis Cole, n. sp.

Plate 2, figures 4, 6

Two specimens were found that yielded median sections, but in one section the outlines of the embryonic chambers were not sufficiently distinct for detail ed measurements. 
The specimen that produced the best median section has a height of $2.5 \mathrm{~mm}$ and a width of $2.14 \mathrm{~mm}$. As the edges of this specimen are broken, its actual size was slightly greater. The initial chamber is spherical, with an internal diameter of $120 \mu$. The second chamber is reniform with diameters of 160 and $40 \mu$. There are three whorls. The first chamber after the embryonic chambers is the only one not subdivided into chamberlets. The second chamber contains 5 chamberlets.

Locality: Station S-24, rare.

Type material: Holotype, median section: U.S.N.M. 560272.

The median section resembles one illustrated by Whipple (1932, p. 83, pl. 20, fig. 9) from the Eocene of Eau (Eua), Tonga. Whipple believed this specimen to be close to $H$. reticulata Rutimeyer, a European species from the Eocene to which most of the IndoPacific specimens from the Eocene have been referred.

\section{Genus SPIROCLYPEUS H. Douvillé, 1905}

Spiroclypeus higginsi Cole

Plate 4, figures $1-3,13,14,19$; plate 5 , figures $10-12$; plate 8 , figures 16,17

1939. Spiroclypeus higginsi Cole, Jour. Paleontology, vol. 13, pp. 185-186, pl. 23, figs. 10-15; pl. 24, fig. 13.

Numerous unoriented thin sections were available, but only one oriented transverse section was made from matrix-free specimens. A description of this section follows:

Test evenly lenticular with a slight flange; total height $2.5 \mathrm{~mm}$; thickness through center $1.1 \mathrm{~mm}$; height of inflated portion $2.0 \mathrm{~mm}$; thickness of flange $0.12 \mathrm{~mm}$.

The embryonic chambers are not completely exposed as only the large initial chamber shows. This chamber has an internal diameter of $140 \mu$. The wall surrounding this chamber has a thickness of about $25 \mu$.

There are 7 lateral chambers to a tier on either side of the embryonic chambers. These decrease regularly in number so that the inner portion of the flange is covered by only one layer of lateral chambers and the outer portion is composed only of the equatorial layer. The lateral chambers are slitlike between thick roofs and floors. These chambers have an average length of $120 \mu$ and a height of about $20 \mu$. The roofs and floors have an average thickness of about $40 \mu$.

Pillars are spaced at rather regular intervals throughout the inflated portion of the test. Those in the central area are the largest with a surface diameter of about $200 \mu$, and the smaller ones diameters of 40-80 $\mu$.

Localities: Stations S-31 S-34a, S-34b, S-34c, rather common in random thin sections.
At station S-34a, associated specimens have a large umbonal pillar that terminates in a large surface pustule. Otherwise, these specimens a re so similar to $S$. higginsi that they are included in that species in this report. A description of these forms follows:

Test small, greatest thickness at the center, sloping rather regularly to the bluntly rourded periphery, apparently without a flange. Surface ornamentation consisting of a prominent umbonal pillar head 300-500 $\mu$ across and some shallow polygonal pits on the remainder of the surface of the test. Height of test 2.0-2.1 mm, thickness $1.0-1.1 \mathrm{~mm}$.

The median sections show a bilocular embryonic apparatus with a subcircular initial chamber having internal diameters of $130 \times 140 \mu$ to $140 \times 180 \mu$. The second chamber is reniform, with intermal diameters of $60 \times 160 \mu$ to $100 \times 230 \mu$. The outer rall has a width of about $30 \mu$. One, undivided, opersuline chamber follows the embryonic chambers.

The chamberlets near the periphery of the test are rectangular with internal diameters of 80 by $160 \mu$. Transverse sections shows the equatorial layer is very thin with an average internal height of $30 \mu$. The equatorial layer is about the same thiskness from the center of the test to the periphery.

The lateral chambers are very thin and compressed with thick roofs and floors. There are 4 layers to a tier on each side of the embryonic arparatus. They decrease regularly in number toward the periphery. Lateral chambers have a length of 100 to $120 \mu$ and a height of about $15 \mu$. The roofs and floors have average thicknesses of about $40 \mu$.

The central area of the test is dominated by a massive pillar on each side of the embryonic apparatus, which have surface diameters of 300 to $500 \mu$. Small pillars, spaced at rather regular intervals throughout the remainder of the test, have surface dismeters of 60 to $80 \mu$.

Locality: Station S-34a, rare.

Random sections of small specimens of Spiroclypeus found in some thin sections apparently represent $S$. higginsi. Measurements of several sections are given.

The diameter of the test is 2.1 to $2.2+\mathrm{mm}$, of which the inflated portion has a diameter of 1.5 to $1.8 \mathrm{~mm}$. A small flange with a width of about $0.4 \mathrm{~mm}$ is present. The thickness at the approximate center of the test is 0.66 to $1.08 \mathrm{~mm}$.

The embryonic chambers were ob erved in three oblique median sections. The subcircular initial chamber has internal diameters of $100 \times 120 \mu$; the reniform second chamber has internal diamete"s of $60 \times 140 \mu$ to $100 \times 180 \mu$. The distance across both chambers including the outer wall is 220 to $260 \mu$ and the outer wall has a thickness of $20 \mu$. There is apparently only 
one undivided chamber following the embryonic chambers.

Chamberlets near the periphery of this section have a radial diameter of $120 \mu$ and a tangential diameter of 50 to $60 \mu$.

The lateral chambers are very appressed, appearing slit-like between thick roofs and floors. There are 4 to 8 layers of lateral chambers on each side of the median layer which is about $20 \mu$ thick from the center to the periphery. The walls and floors of the lateral chambers are about $60 \mu$ thick and the internal height of the lateral chambers is 10 to $15 \mu$. The length of the lateral chambers is about $120 \mu$.

Small pillars have a surface diameter of 40 to $60 \mu$.

This species, described from Guam, is associated with Miogypsinoides formosensis Yabe and Hanzawa and Borelis pygmaeus (Hanzawa) at station $\mathrm{S}-34 \mathrm{~b}$, which is the same association as in Guam. At S-34c it occurs with Lepidocyclina.

\section{Spiroclypeus tidoenganensis van der Vlerk}

Plate 3, figures $1-12$; plate 4 , figures $6-12$; plate 7 , figures $7-11$

1925. Spiroclypeus tidoenganensis van der Vlerk, Nederlandsche Akad. Weten. Meded., no. 3, p. 16, pl. 1, fig. 12; pl. 5, figs. 42,47 .

1925. Spiroclypeus tidoenganensis van der Vlerk, Geol. Mijn. Gen. v. Ned. en Kol., Verh., geol. ser., vol. 8, pp. 561-562, pl. 1.

1931. Spiroclypeus tidoenganensis van der Vlerk. Krijnen, W. F., ibid., vol. 9, pp. 83, 90, table opp. p. 84, pl. 2, figs. $1-5,7$.

1937. Spiroclypeus tidoenganensis van der Vlerk. Tan, S. H., De Ing. in Ned.-Indië, 4, Jaarg. 4, no. 10, pp. 182, 183, pl. 1 , fig. 10 ; pl. 2 , figs. 4 , 5 ; pl. 3 , fig. 12 ; pl. 4, figs. $2-5$, 19-21.

Megalospheric form.-Test has an inflated portion bordered by a rather thin flange; average specimens have a diameter of about $5 \mathrm{~mm}$ of which 3 to 4 is taken by the inflated portion; thickness 1.82 to $1.96 \mathrm{~mm}$; flange thickness, $0.16 \mathrm{~mm}$. The inflated portion has rather evenly distributed papillae that project slightly above the surface of the test. The papillae have a diameter of about $50 \mu$. In slightly weathered specimens the positions of the papillae is revealed by small, round pits as the papillae weather more readily than the remainder of the test (pl. 3, fig. 12). The flange has concentric, slightly raised white lines, which represent the surface expression of the sutures of the main chamber walls. The chamberlet sutures can be made visible by moistening the surface of the flange. Papillae are not developed on the flange, although the sutures of some specimens seem to be slightly beaded.

The embryonic apparatus consists of a subspherical initial chamber followed by a reniform chamber.
Diameters of embryonic chambers

\begin{tabular}{|c|c|c|c|c|}
\hline & 1 & 2 & 3 & 4 \\
\hline $\begin{array}{l}\text { Diameter of initial chamber }(\mu) \\
\text { Diameter of second chamber }(\mu) \\
\text { Diameter across both chambers }(\mu)\end{array}$ & $\begin{array}{r}560 \times 420 \\
580 \times 240 \\
660\end{array}$ & $\begin{array}{r}380 \times 300 \\
340 \times 160 \\
480\end{array}$ & $\begin{array}{r}320 \times 300 \\
340 \times 140 \\
440\end{array}$ & $\begin{array}{r}500 \times 320 \\
500 \times 280 \\
620\end{array}$ \\
\hline
\end{tabular}

The height of the embryonic chambers as obserred in vertical thin section is $620 \mu$. The embryonic chambers are bounded by a relatively thick wall on the side from which the spire develops, and by a thin wall on the side on which the chamberlets develop.

The embryonic chambers are followed by an undivided operculine chamber. The following chambers are divided into heterostegine chamberlets. The chamber following the undivided chamber contains 3 chamber Jets in most specimens, but one specimen has 7 chamberlets in the first subdivided chamber.

Specimens of average size have $2 \frac{1}{2}$ to $23 / 4$ whorls, which gradually increase in size as they are added. A thick spiral wall separates the whorls.

The embryonic chambers are covered on each side by 7 to 9 layers of lateral chambers. The flange is either not covered by lateral chambers or has one row. The opening of the lateral chambers is low, appres*ed between thick roofs and floors. Lateral chambers are as much as $30 \mu$ high and about $160 \mu$ long. Roofs and floors have thicknesses of $40-80 \mu$.

The pillars are rather heavy especially in the central area. These pillars taper near the equatorial layer. Surface diameter of the pillars is 100 to $200 \mu$.

Microspheric form.-Test more than $10.5 \mathrm{~mm}$ across, composed of small, inflated, central area 1.9 to $2.2 \mathrm{~mm}$ in diameter surrounded by a broad flange. The inflated central area is $2.2 \mathrm{~mm}$ thick and the flange $0.88 \mathrm{~mm}$. Surface bears slightly elevated papillae that average $160 \mu$ in diameter. The papillae are closer together on the inflated area than on the flange. Between the papillae the surface is smooth.

The equatorial section has $51 / 8$ whorls which start from a minute embryonic chamber. There are 16 undivic $9 d$, operculine chambers after the initial chamber. The chambers beyond these are subdivided into chamberlots.

There are about 10 lateral chambers on each side of the equatorial plane at the center of the test. The flange has 3 to 4 layers of lateral chambers on each side of the median plane throughout the width of the flange. The lateral chambers are low, appressed between trick roofs and floors. The lateral chambers nearest the median plane are virtually without a chamber cavity, but the peripheral chambers have thinner roofs and floors and a distinct chamber cavity.

Heavy massive pillars occur in the central area; some taper regularly toward the median plane, but others are 
virtually straight nearly to the median plane, beyond which they taper rapidly. The pillars of the flange are smaller, much farther apart, and cylindrical. Pillars of the central area have a surface diameter of as much as $500 \mu$, and those of the flange a surface diameter of as much as $180 \mu$.

Locality: Station S-3, common; station S-30, megalospheric specimens in such abundance that the sample is largely composed of their tests; only 4 microspheric specimens recovered; station 31 , rare.

Discussion.-This species belongs to the group which Tan (1937, p. 182) has designated the pustulate type. Van der Vlerk's original figure and description demonstrate that in this form there is an undivided chamber followed by a chamber subdivided into 7 chamberlets. Although the specimens from Saipan typically have 3 chamberlets in the first subdivided chamber, one median section agrees with the one of the cotypes by having 7 chamberlets in the first subdivided chamber.

A section through the lateral chambers parallel to the median plane reveals features shown by a similar section figured by Tan (1937, pl. 3, fig. 12).

Umbgrove (1931, p. 84) states that the range of $S$. tidoenganensis is from the base of $e_{1}$ to (and possible including) the base of $e_{5}$.

Recently, the writer studied in detail some sfecimens in the U. S. National Museum from Hikun on the Sungai river, Tabalong southeast Borneo, assigned by Douville (1905, pp. 462-464, pl. 14, figs. 7-9) to S. pleurocentralis Carter. These specimens will be illustrated and described in detail in a forthcoming publication on Foraminifera from the Bikini test wells. It is sufficient to state here that these specimens represent $S$. tidoeganensis van der Vlerk, not S. pleurocentralis.

\section{Spiroclypeus orbitoideus H. Douville}

Plate 4, figures 4, 5

1905. Spiroclypeus orbitoideus H. Douville, Bull. Soc. Geol. France, ser. 4, vol. 5, pp. 460-462, pl. 14, figs. 1-6.

1924. Spiroclypeus orbitoideus H. Douville. Rutten, Jaar. Mijn. in Ned. Oost-Indië, Verh., Jaarg. 52 (1923), pp. 180, 181, figs. 1-6, 8, 12-21.

1932. Spiroclypeus orbitoideus H. Douvillé. Krijnen, Geol. Mijn. Gen. v. Ned. en Kol., Verh., geol. ser., vol. 9, p. 91 , pl. 3 , figs. 7,8 .

1937. Spiroclypeus orbitoideus H. Douville. Tan, De Ing. in Ned.-Indië, 4, Jaarg. 4 , no. 10 , pp. $182,183,184$, pl. 1 , figs. $2-4$; pl. 2 , figs. $1-3,11$; pl. 3 , figs. $1-7$; pl. 4 , fig. 1 .

This species is poorly defined in the literature. It appears to be characterized by lateral chambers with large, open cavities between thin floors and roofs arranged in regular tiers. The transverse section superficially looks like that of a lepidocycline.

Tan (1937, p. 187) in a discussion of this species states that individuals from "Sg. Riko (Balikpapan Bay,
No. 394Z)" attain a diameter of 4 to $7 \mathrm{~mm}$ and have an embryonic apparatus of 0.26 to $0.7 \mathrm{~mm}$ in diameter. Tan figures a specimen with a height of $7.6 \mathrm{~mm}$ and a thickness of $3.6 \mathrm{~mm}(1937, \mathrm{pl}$. 2, fig. 4) that is very similar to a transverse section from station S-3, Saipan, except that it is larger. A description of the specimen from Saipan follows:

The height of the specimen is $3.4 \mathrm{~mm}$ of which about $0.5 \mathrm{~mm}$ is a thin flange $0.12 \mathrm{~mm}$ thick without a covering of lateral chambers. The thickness through the center of the test is $1.26 \mathrm{~mm}$.

The initial chamber has internal diameters of $160 \times 180$ $\mu$ and the second has diameters of $140 \times 100 \mu$. The distance across both chambers is $300 \mu$.

There are eight lateral chambers to a tier on each side of the median layer at the center of the test. These chambers have an internal height of about $40 \mu$, a length of 100 to $200 \mu$, and the floors $\varepsilon$ nd roofs have a thickness of about $20 \mu$.

A large umbonal pillar on one side of the test has a surface diameter of $340 \mu$. Smaller pillars have surface diameters of about $60 \mu$.

One imperfect transverse thin section from station $\mathrm{S}-16$ shows many of the features of this species. This section has a height of $3.0 \mathrm{~mm}$, but a considerable portion of the lower edge is missing so that the original height must have been 3.5 to $4 \mathrm{~mm}$. The thickness at the center is $1.8 \mathrm{~mm}$. Two large umbonal pillars have surface diameters of 700 and $900 \mu$ resnectively. The lateral chambers are arranged in regular tiers, and are open, with thin roofs and floors.

Localities: Stations S-3, S-14, S-16, very rare.

\section{Genus CYCLOCLYPEUS W. B. Carpenter, 1856}

Cycloclypeus (Cycloclypeus) carpenteri Brady

Plate 14, figures 5, 6

1881. Cycloclypeus carpenteri Brady, Quart. Jour. Micr. Sci., London, n. s., vol. 21, pp. 66, 67.

This species is represented in the present collection by random vertical sections. Measuroments of three sections of specimens from Tinian, sample $T-7$, are given for comparison. The specimens from Saipan have the same structures and measurements, but as the sections are very fragmentary, the better-preserved specimens from Tinian Island are measured and figured.

Measurements of Cycloclypeus (Cycloclyr:us) carpenteri

\begin{tabular}{|c|c|c|c|}
\hline & 1 & 2 & 3 \\
\hline $\begin{array}{l}\text { Total diameter }(\mathrm{mm}) \\
\text { Diameter of umbo }(\mathrm{mm}) \\
\text { Thickness of umbo }(\mathrm{mm}) \\
\text { Width of flange }(\mathrm{mm}) \\
\text { Thickness of flange }(\mathrm{mm}) \\
\text { Diameter of pillars }(\mu)\end{array}$ & $\begin{array}{r}5.06 \\
2.03 \\
1.04 \\
1.5 \\
100-120\end{array}$ & $\begin{array}{r}7.0 \\
2.3 \\
1.1 \\
2.4 \\
60-36 \\
-100\end{array}$ & $\begin{array}{r}4.8 \\
3.0 \\
.96 \\
.8 \\
80-120\end{array}$ \\
\hline
\end{tabular}


The Bikini resurvey expedition during the summer of 1947 dredged specimens of both the microscopic and megalospheric forms of Cycloclypeus from the seaward slope off the north end of Bikini, Bikini Atoll, in water 580 to $800 \mathrm{ft}$ deep. Vertical thin sections of these specimens are identical with those from station $\mathrm{T}-7$ and from the Saipan localities.

Localities: S-4, S-7, rare: T-7, abundant.

\section{Cycloclypeus (Cycloclypeus) eidae Tan}

Plate 5, figures 13-19

1932. Cycloclypeus eidae Tan, Nederlandsche Akad. Wetens. Meded. No. 19, pp. 50-59, pl. 5, fig. 6; pl. 12, figs. 2, 3; pl. 13, figs. 1, 2, 4-6 (references and synonomy).

1932. Cycloclypeus neglectus Martin, var. eidae Tan. Caudri, Geol. Mijn. Gen. v. Ned. en Kol., Verh., geol. ser., vol. 9 , pp. 186-187, figs. $15,16$.

1945. Cycloclypeus (Cycloclypeus) eidae Tan. Cole, Bernice P. Bishop Mus., Bull. 181, p. 280, pl. 14, figs. A-D.

The test is thin and fragile, has a rather distinct umbo ornamented by irregularly spaced papillae, and concentric rings of less distinct papillae on the brim. The diameter is 3.4 to $4.0 \mathrm{~mm}$ and the thickness through the center about $0.5 \mathrm{~mm}$.

The protoconch is small and has an internal diameter of $40 \mu$ ( 1 specimen), $60 \mu$ ( 2 specimens), and $80 \mu$ (1 specimen). There are 18 nepionic septa in two specimens, 19 in another and 22 in the fourth. Three of the specimens have two undivided chambers following the embryonic chambers, and one of the specimens has one.

Localities: Station S-34a, common; S-36, rare.

Remarks.-Cole $(1945$, p. 279) has indicated that Tan's classification (Tan, 1936), of the genus Cycloclypeus is not satisfactory, but the specimens in the present collection fall readily into Tan's definition of this species.

\section{Family PENEROPIIDAE}

Genus Sorites Ehrenberg, 1840

Sorites martini (Verbeek)

Plate 12, figure 11; plate 14, figures 1,2

1896. Orbitolites martini Verbeek, Descrip. geol. de Java et Madoura, Nederlandsche Akad., a 2-vol. book published in Amsterdam in 1896, vol. 2, p. 1159, pl. 9, figs. 134-135.

Only two species of Sorites have been reported from the Miocene of the eastern Pacific. The recent species, S. marginalis, is supposed to occur in the Miocene "f" of Java and the present species has been reported from Miocene "e" from many localities.

The specimens from Saipan show the general features of $S$. marginalis, but attain a much larger size. Verbeek's illustration of a transverse section shows markedly chevron-shaped chamber divisions. Most of the chamber divisions of the specimens from . Saipan are straighter but a few are chevron-shaped.
Only tentative identification is possible from the present material. In fact, even well-preserved materiq] presents considerable difficulty in determining not only specific but even generic characters.

Localities: Stations S-33a and S-33c, rather common; station S-33bc, rare.

\section{Family ALVEOLINELLIDAE}

\section{Genus Borelis Montfort, 1808}

\section{Borelis pygmaeus Hanzawa}

Plate 12, figure 16; plate 13, figures 4-7

1929. Borelis sp. Yabe and Hanzawa, Tohoku Imp. Univ., Esi. Rept., ser. 2 (Geol.), vol. 11, no. 3, p. 181, pl. 15, figs. 12, 13 ; pl. 23, fig. 7 .

1930. Borelis (Fasciolites) pygmaea Hanzawa, ibid., vol. 14, no. 1, p. 94, pl. 26, figs. 14-15.

1932. Neoalveolina pygmaea (Hanzawa). Bakx, Geol. Mijn. Gon. v. Ned. en Kol., Verh., geol. ser., vol. 9, pp. 237-239, pl. 3, figs. 18-20.

1939. Neoalveolina pygmaea (Hanzawa). Cole, Jour. Pal., vol. 13, no. 2 , p. 187 , pl. 24 , fig. 8 .

1947. Borelis pygmaeus Hanzawa, Japanese Jour. Geol. Geog., vol. 20, nos. 2-4, pp. 9-11, pl. 5, figs. 1-4.

Four small fusiform specimens from Saipan have the following measurements:

\begin{tabular}{|c|c|c|c|c|}
\hline & 1 & 2 & 3 & 4 \\
\hline $\begin{array}{l}\text { Height }(\mathrm{mm}) \\
\text { Length }(\mathrm{mm}) \\
\text { Coils }(\mathrm{no} .)^{2}\end{array}$ & $\begin{array}{r}0.8 \\
1.8 \\
10+\end{array}$ & $\begin{array}{l}0.6 \\
1.3 \\
6\end{array}$ & $\begin{array}{l}0.74 \\
1.48 \\
6\end{array}$ & $\begin{array}{l}0.9 \\
2.2\end{array}$ \\
\hline
\end{tabular}

Hanzawa (1947) has given a complete description of specimens from Saipan.

Localities: Station S-3, rare; station S-13, abundart; stations $\mathrm{S}-17, \mathrm{~S}-26$, and $\mathrm{S}-34 \mathrm{~b}$, rare.

\section{Family ROTAIIIDAE \\ Genus STREBLUS Fischer, 1817 \\ Streblus saipanensis Cole, $\mathbf{n}$. sp. \\ Plate 5, figures 8,9}

The test is plano-convex, with the dorsal side flat and the ventral side strongly convex; all the volutions are visible on the dorsal side, but only the final volution is visible on the ventral side; on the ventral side there is a slight umbilical depression; the final chamber is slightly inflated and prolonged, and the wall is highly ornamented with small raised pustules of clear sholl material. The wall ornamentation largely conceals the sutures so that only the final three chambers can be recognized clearly; diameter 0.66 to $1.4 \mathrm{~mm}$; height about $0.8 \mathrm{~mm}$.

Median and transverse sections reveal the coiling to be rotalid. The chamber walls are composed of an inner series of small pillarlike structures between whirh 
there are minute canals, and an outer series of large pillarlike structures that form the surface rugosities. The large pillars have small inner ends but expand rapidly to an external bulbous end.

There are two initial chambers; the first is nearly circular and has an internal diameter of about $80 \mu$; the second is subglobular and has internal diameters of about $60 \times 100 \mu$.

The chamber walls are nearly straight and radial. Some bifurcate at their proximal ends, others are simple.

Locality: Station S-34a, common.

Type material: Holotype: U.S.N.M. 560273.

Externally this species resembles Rotalia elphidroides Caudri (1934, pp. 148-150, pl. 5, figs. 13-17) described from the Tertiary "f" of Soemba. However, $S$. saipanensis is smaller and decidedly asymmetrical, and has fewer chambers.

\section{Family CYMBALOPORIDAE}

Genus FabIanIa A. Silvestri, 1926

Fabiania saipanensis Cole, n. sp.

Plate 15, figures 1, 2

One thin section from station $\mathrm{S}-32$ c reveals a welloriented axial section that has the characteristics of Fabiania Silvestri (1926). Specimens referrable to this genus were later described by Cole and Bermudez (1944, pp. $336-340$, pl. 1, fig. 1; pl. 2, figs. 1-12; pl. 3, figs. 1-5) as Eodictyoconus, a generic name that must be suppressed in favor of Fabiania, which has priority.

Although this species is based on a single axial section, it is believed that no confusion will result because only two other species of this genus have been described. A description of the axial section follows:

The diameter at the base is $3.2 \mathrm{~mm}$ and the height is $1.1 \mathrm{~mm}$. The test is conical or irregularly conical and has a deeply excavated umbilicus. The thickness of the test is $0.3 \mathrm{~mm}$.

One of the embryonic chambers, located at the apex of the test, is seen in the axial section. This chamber has internal diameters of $80 \times 160 \mu$ and is surrounded by a wall $20 \mu$ thick.

The chambers comprising the test are shown in the illustrations. In the axial section the test seems to be composed of a single layer of chambers. From the inside of the external wall two or more plates project into these chambers. "The outer wall of the test is coarsely perforate.

Type material: Holotype, transverse section, U.S.N.M. 560276 .

Family VICTORIELLIDAE

Genus VICTORIELLA Chapman and Crespin, 1930

Victoriella plecte (Chapman)

Plate 14, figure 4
1922. Carpenteria proteiformis, var. plecte Chapman, Reconn. Geol. Survey Victoria, vol. 4, p. 320, pl. 51, fig. 3.

1930. Sporadotrema cylindricum Hanzawa (not Carter), Tohoku Imp. Univ., Sci. Rept., ser. 2 (Geol.), vol. 14, p. 94, pl. 27, figs. 1, 2.

1930. Victoriella plecte Chapman and Crespin, Proc. Royal Soc. Victoria, vol. 42, pp. 110-112, pl. 7, figs. 1-4.

Hanzawa illustrates two specimens from random thin sections made from limestone collected at "** * a limestone cliff at the northern front of Pasir Pabesan lying to the west of the village Tagogopoc" (Gunung Pabesan), Java, that are similar in every respect to the specimens from Saipan.

Chapman and Crespin established the genus Victoriella for Australian specimens that Chapman originally included in Carpenteria proteiformis plecte. The specimens from Java and Saipan are okviously different from the recent Sporadotrema cylindricum, but are very similar to the specimens described from Australia.

Tictoriella was illustrated by two external views and two thin sections but, unfortunately, the photomicrographs of the thin sections are rather dark and hazy. However, the visible details so closely resemble features of the specimens from Saipan that the latter are referred to the Australian species.

Locality: Station S-34b, common.

\section{Family ORBITOIDIDAE Schubert, 1920}

Genus Lepidocyclina Gïmbel, 1870

Subgenus NEPHROLEPIDINA H. Dorvillé, 1911

Lepidocyclina (Nephrolepidina) brouw ri L. Rutten

Plate 8, figure 1; plate 9, figure 1; plate 11, figure 3; plate 12, figures 5,14

1923. Lepidocyclina brouweri L. Rutten, Jaar. Mijn. in Ned. Oost-Indië, Verh., p. 182, figs. 22-2?.

The original description of this species is incomplete and it is illustrated by drawings rathe ${ }^{n}$ than photomicrographs. It is distinguished by relatively heavy pillars, open lateral chambers that have straight floors and roofs, and lateral chambers arranged in regular tiers.

One oriented vertical section found in the random thin section from station $\mathrm{S}-3$, and several oblique sections from $S-34 a, b$, and $c$, were tertatively identified with this species. Although the specimens are poorly preserved, it is evident that th oy represent $L$. (N.) brouweri, or a related species.

The essential measurements of the oriented thin section follow:

Diameter, $2.5+\mathrm{mm}$; diameter of umbo, $1.6 \mathrm{~mm}$; width of flange, $0.6 \mathrm{~mm}$; thickness of flange, $0.14 \mathrm{~mm}$; thickness through center, $0.9 \mathrm{~mm}$; length of the embryonic chambers, $180 \mu$; height of embryonic chambers, $120 \mu$; thickness of outer wall of embryonic chambers, $20 \mu$; height of the equatorial layer at the center of the 
test is $25 \mu$ and at the periphery, $60 \mu$; number of lateral chambers on each side of the equatorial layer at the center of the test, 9 ; length of the lateral chambers at the periphery of the test, $120-140 \mu$; height of the lateral chambers, $25 \mu$; thickness of the floors and roofs, $5 \mu$; surface diameter of the pillars, $140-200 \mu$.

This species is associated with Spiroclypeus orbitoideus at its type locality at Maros, Celebes, and also at station S-3.

An oblique section from station S-34c (pl. 12, fig. 14) represents a specimen having a relatively broad, thin keel and a few, scattered, heavy pillars. The equatorial chambers are diamond-shaped. The general proportions and the few observable features reveal close similarities to the vertical section described from station $\mathrm{S}-3$. Therefore, this specimen is included in this species.

A single specimen of Lepidocyclina discovered in the random thin sections from station $\mathrm{S}-34 \mathrm{~b}$ shows a remarkable similarity to one from Gunung Pabeasan, Java (Hanzawa, 1930, pl. 27, fig. 11, left) identified as L. (Nephrolepidina) ferreroi Provale. Miss Caudri (1939, p. 224) has questioned this identification.

The heavy pillars and open lateral chambers of this specimen identify it with $L$. $(N$.) brouweri.

Two free specimens from station S-34a are worthy of note. One is a megalospheric and the other a microspheric specimen but, without adequate vertical sections, it is impossible to be certain of the specific identity. The shape of the equatorial chambers suggests that they belong in the parva-brouweri group, but inasmuch as they are definitely not $L$. (N.) parva, it was decided to include them under the specific name brouweri, but give as complete a description of them as possible.

The megalospheric specimen (pl. 8, fig. 1) is a small compressed lenticular test that has a diameter of 2.2 $\mathrm{mm}$ and a thickness of $0.92 \mathrm{~mm}$. Surface bears rather widely scattered low papillae between which occur polygonal shallow pits bounded by low ridges of clear shell material. The surface diameter of an average papilla is about $120 \mu$.

The nephrolepidine embryonic apparatus consists of a subcircular initial chamber that has internal diameters of $100 \times 120 \mu$. The second chamber, which only slightly embraces the initial chamber, has internal diameters of $80 \times 160 \mu$. The distance across both chambers is $180 \mu$. Two distinct periembryonic chambers occur, one at either end of the partition dividing the embryonic chambers.

The equatorial chambers are diamond-shaped with radial and tangential diameters of about $60 \mu$.

Externally, this specimen resembles one illustrated by Yabe and Hanzawa (1925, pl. 2, fig. 1) from the $\mathbf{2 3 6 1 5 5 - 5 3 - 3}$
Klias peninsula, under the name Lepidocyclina (Nephrolepidina) mariae $\mathbf{R}$. Douvillé. This specimen is a microspheric individual about $4 \mathrm{~mm}$ in diameter whereas the specimen from Saipan is a megalospheric individual $2.2 \mathrm{~mm}$ in diameter.

The associated microspheric specimen (pl. 9, fig. 1) is a test having an inflated central part that merges imperceptibly with a narrow rim; diameter, about 4.0 $\mathrm{mm}$; thickness, about $1.0 \mathrm{~mm}$; width of rim, about 0.6 $\mathrm{mm}$. The surface has an apical group of rather strong papillae, and the rest of the surface is covered by shallow polygonal pits. There are about 11 papillae in the apical group, ranging from 200 to $300 \mu$ in diameter.

The specimen has diamond-shaped equatorial chambers whose radial and tangential diameters are about $60 \mu$.

The external appearance of this specimen is remarkably like that of a specimen identified as Lepidocyclina angulosa by H. Douvillé (1912, pl. 21, fig. 3) from Hiligara and, more recently, Caudri $(1939$, p. 175$)$ placed this specimen under the name L. perornata (Douvilló)? It is certain that neither of these identifications is correct.

In the Oligocene of the area about the Gulf of Mexico a small species of Lepidocyclina, L, yurnagunensis, is commonly associated with a variety, L. yurnagunensis morganopsis Vaughan, that differs chiefly in having heavy pillars.

Lepidocyclina parva and $L$. brouweri apparently have the same relationships. L. parva lacks pillars or has very small ones, whereas $L$. brouweri has heavy pillars. In their other features the two species are nearly alike.

Locality: Stations S-3, S-34a, S-34b, and S- 4 c; very rare.

Lepidocyclina (Nephrolepidina) newtoni Yabe and Hanzava Plate 12, figures 8-10, 15; plate 14, figure 3

1930. Lepidocyclina (Nephrolepidina) newtoni Yabe and Hanzawa, Tohoku Imp. Univ., Sci. Rept., ser. 2 (Geol.), vol. 14 , pp. 28,29 , pl. 5, figs. $1,2$.

This species is represented by random sections, none of which are well oriented. The largest specimen has a diameter of $4.5 \mathrm{~mm}$ and a thickness of $1.2 \mathrm{~mm}$. The central area is flat, lenticular, and bordered by a moderately broad flange.

An oblique equatorial section reveals nephrolepidine embryonic chambers. The initial chamber has internal diameters of $220 \times 240 \mu$; the second chamber has diameters of $100 \times 220 \mu$; the distance across both chambers is $320 \mu$ and the outer wall has a thickness of $40 \mu$.

The equatorial chambers near the periphery are short spatulate with radial diameters of about 1 in $\mu$ and tangential diameters of about $140 \mu$. The height of the equatorial layer near the center is about $80 \mu$ and at the periphery about $120 \mu$. 
There are about 7 lateral chambers to a tier on each side of the equatorial layer at the approximate center of the test. Apparently, pillars are absent.

Locality: Station S-13, common.

This species was described from random sections from the Kaizan beds of Formosa. The specimens from Saipan resemble the illustrations given by Yabe and Hanzawa.

\section{Lepidocyclina (Nephrolepidina) parva Oppenoorth}

Plate 7, figure 6; plate 9 , figures 5-12, 15-18; plate 10 , figures 11-18; plate 11, figures 1,2 ; plate 12 , figure 6 .

1918. Lepidocyclina parva Oppenoorth, Geol. Mijn. Gen. v. Ned. en Kol., Verh., geol. ser., vol. 2, p. 255, pl. 8, figs. 11-12; pl. 9, fig. 9.

1928. Lepidocyclina (Nephrolepidina) parva Oppenoorth. van der Vlerk, Eclog. Geol. Helv., vol. 21, p. 187, pl. 12, figs. 24a-b.

1928. Lepidocyclina (Nephrolepidina) isolepidinoides van der Vlerk, Nederlandsche Akad. Wetens. Meded., no. 9, pp. 23, 24, figs. 20, 45a-b, 48a-c.

1930. Lepidocyclina (Nephrolepidina) melanesiana Hanzawa, Tohoku Imp. Univ., Sci. Rept., ser. 2 (Geol.), vol. 14, p. 93 , pl. 26, figs. 3-5, 8, 11-14, 17; pl. 27, figs. 3-5, 9-13, 16.
1934. Lepidocyclina parva Oppenoorth. Caudri, Tertiary deposits of Soemba, Amsterdam, pp. 104-105.

1939. Lepidocyclina (Nephrolepidina) parva Orpenoorth. Cole, Jour. Paleontology, vol. 13, p. 188, pl. 23, figs. 1-7.

1939. Lepidocyclina parva Oppenoorth. Caudri, Geol. Mijn. Gen. v. Ned. en Kol., Verh., vol. 12, p. 244.

1939. Lepidocyclina isolepidinoides van der Vlerk. Caudri, ibid., pp. 244, 245.

Two recorded species of small Lepidocyclina, $L$. (Nephrolepidina) parva and $L .(N$.$) isolepidinoides,$ have many features in common. In the preliminary work on the specimens from Saipan bcth species were identified. Specimens from station S-25 were referred to $L$. (N) parva and those from station S-13 to $L$. $(N$.$) isolepidinoides. Similar specimens from station$ S-34a were placed in a third species 1 acause of their slightly greater size.

Detailed examination, however, showed a rather complete gradation among the three groups, and critical measurements of various lots of specimens led to the conclusion that only one species is represented (see table below). For completeness, the three forms are described separately.

TABLE 5.-Measurements of specimens referred to Lepidocyclina (Nephrolepidina) parva Oppenoorth

\begin{tabular}{|c|c|c|c|c|c|c|c|c|}
\hline & \multirow{2}{*}{$\begin{array}{l}\text { Lepidocyclina } \\
\text { (Nephrolepi- } \\
\text { dina) parva }\end{array}$} & \multirow{2}{*}{$\begin{array}{l}\text { Lepidocyclina } \\
\text { (Nephrolepi- } \\
\text { dina) isoepi- } \\
\text { dinoides? }\end{array}$} & \multirow{2}{*}{$\begin{array}{l}\text { Lepidocyclina } \\
\text { (Nephrolepi- } \\
\text { dina) melane- } \\
\text { siana }\end{array}$} & \multirow{2}{*}{ Guam 4} & \multirow{2}{*}{ Station 9-25 (Saipan) } & \multicolumn{2}{|c|}{ Statior S-34a } & \multirow{2}{*}{$\begin{array}{l}\text { Station } \\
\text { S-13 }\end{array}$} \\
\hline & & & & & & Small & Large & \\
\hline Diameter (mm) & \multirow{6}{*}{$\begin{array}{l}\text { 1. 2-2.0 } \\
0.6-1 \\
\text { None }\end{array}$} & 1.2 & \multirow{4}{*}{$\begin{array}{r}2.2 \\
1.1 \\
\text { Present }\end{array}$} & \multirow{3}{*}{$\begin{array}{r}1.1-1.7 \\
0.56-0.68 \\
\text { Present }\end{array}$} & \multirow{3}{*}{$\begin{array}{l}\text { 1. } 0-1.4 \\
\text { 0. } 6-0.7 \\
\text { Slight }\end{array}$} & 1. $1-1.3$ & \multirow{3}{*}{$\begin{array}{r}2.0-2.6 \\
0.66-0.78 \\
0.3-0.4\end{array}$} & \multirow{3}{*}{$\begin{array}{r}1.5 \\
0.8 \\
0.12\end{array}$} \\
\hline Thic & & 0.75 & & & & $0.5-0.6$ & & \\
\hline Peripheral flange (mm) & & 0.2 & & & & $\ldots$ & & \\
\hline $\begin{array}{l}\text { Embryonic chambers: } \\
\text { Diameter of initial cham- }\end{array}$ & & & & & & & & \\
\hline ber $(\mu)$ & & $80 \times 130$ & & $100 \times 200$ & $80-140 \times 140 \times 180$ & $80 \times 100$ & $70 \times 140$ & $80 \times 120$ \\
\hline Diameter of second chamber & & $70 \times 160$ & & $100 \times 150$ & $60-120 \times 120-240$. & $50 \times 100$ & $80 \times 180$ & $80 \times 140$ \\
\hline Distance across both cham- & & & & & & & & \\
\hline bers $(\mu)$ & $400(?)$ & 160 & 230 & $220-240$ & $140-280$ & 140 & 160 & 160 \\
\hline $\begin{array}{l}\text { Height of chambers }(\mu) \\
\text { Thickness of outer wall }\end{array}$ & 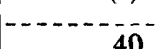 & 110 & 220 & 150 & $120-140$ & $60-100$ & 100 & 100 \\
\hline Lateral chambers: & & & & & & & 25 & \\
\hline $\begin{array}{l}\text { On each side of equatorial } \\
\text { layer at center (no) }\end{array}$ & $8 \pm$ & & 6 & $7-8$ & 7 & $5-6$ & & \\
\hline Height $(\mu)$ & $\frac{1}{50}$ & $50-60$ & 43 & $30-40$ & 40 & $25-40$ & $20-35$ & \\
\hline Length $(\mu)_{-}$ & 150 & 100 & 128 & $80-100$ & 120 & $80-140$ & $80-140$ & 120 \\
\hline $\begin{array}{l}\text { Thickness of floors and roofs } \\
(\mu)\end{array}$ & 15 & 10 & & 20 & & $10-15$ & $15-20$ & $8-10$ \\
\hline Surface diameter of pillars $(\mu)$ & 100 & 100 & 86 & 45 & $40-80$ & $40-100$ & $60-80$ & $50-60$ \\
\hline Equatorial layer: & & & & & & & & \\
\hline $\begin{array}{l}\text { Height at center }(\mu) \\
\text { Height at periphery }\end{array}$ & 40 & 30 & 21 & 30 & 40 & $25-60$ & $20-25$ & $\ldots$ \\
\hline Equatorial chamber & & & & & & & & \\
\hline Radial dian & 60 & 50 & 54 & 60 & 40 & 40 & $50-65$ & 60 \\
\hline Tangential & & & & 40 & 40 & 40 & & \\
\hline
\end{tabular}

1 After Oppenoorth, 1918.

After van der Vlerk, 1928.

After Hanzawa, 1930 .

1 After Cole, 1939. 
FORM AT FIRST ASSIGNED TO LEPIDOCYCLINA (N.) PARVA

Megalospheric form.-Test small, circular, evenly biconvex with slight indication of a narrow rim, ornamentation consisting of a polygonal mesh formed by the lateral chambers; diameter, 1.0 to $1.4 \mathrm{~mm}$; thickness, 0.6 to $0.7 \mathrm{~mm}$.

Embryonic chambers nephrolepidine, consisting of a small initial chamber having diameters $80 \times 140 \mu$ to $140 \times 180 \mu$, followed by a reniform chamber with diameters $60 \times 180 \mu$ to $120 \times 240 \mu$. Total distance across both chambers 140 to $280 \mu$. Height of embryonic chambers as observed in vertical thin section 120 to $140 \mu$. Two periembryonic chambers occur, one at ach end of the dividing partition of the embryonic chambers. One periembryonic chamber has diameters of $40 \times 160 \mu$, the other, diameters of $40 \times 100 \mu$.

Equatorial chambers rhombic, with radial diameters of about $40 \mu$ and tangential diameters of about $40 \mu$. Equatorial layer as observed in vertical sections thin, with a height of $40 \mu$ at the center of the test and a height of $60 \mu$ at the periphery.

There are 7 lateral chambers to a tier on each side of the equatorial layer at the center of the test. These lateral chambers are open, and have very thin roofs and floors arranged regularly in tiers with no overlapping. An average peripheral lateral chamber over the central area of the test has a length of $120 \mu$ and a height of $40 \mu$. The thickness of the roofs and floors is about $5 \mu$. Extremely small pillars occur between some tiers of lateral chambers. The largest pillar has a diameter of $40 \mu$.

Microspheric form.-Test small, circular, evenly biconvex with a diameter about $2.9 \mathrm{~mm}$ and a thickness about $1.5 \mathrm{~mm}$. Surface ornamented with small papillae in the central area with the area surrounding the papillae covered with a polygonal mesh.

Equatorial chambers rhombic except in the peripheral zone where they are hexagonal. Equatorial chambers increase slightly in size from the center of the test to the periphery. Peripheral chambers have radial and tangential diameters of about $40 \mu$. The height of the equatorial layer as observed in vertical sections is about $30 \mu$ at the center of the test and about $60 \mu$ at the periphery.

There are about 14 lateral chambers to a tier on each side of the equatorial layer. The tiers are regularly arranged. The first few lateral chambers above the equatorial layer are appressed and have practically no cavity, but those near the periphery are open and have well-developed chamber cavities. There such chambers are 60 to $80 \mu$ long and 25 to $35 \mu$ high. Floors and roofs are about $15 \mu$ thick.

Heavy pillars are irregularly distributed. These pillars taper but slightly. The surface diameter of the pillars is from 100 to $200 \mu$.
Microspheric individuals are rather abundant at station S-25, but the megalospheric individuals are extremely rare.

The shape of the equatorial chambers and tha arrangement and shape of the lateral chambers ind sate that these megalospheric and microspheric individuals are related.

Hanzawa's specimens from Gunung Pabeasan, Java under the name $L$. (Nephrolepidina) douvillei Yabe and Hanzawa (Hanzawa, 1930, pp. 91, 92; pl. 26, fig. 9; pl. 27 , figs. $6,13-15)$ are identical with the microspheric specimens from station S-25.

\section{FORM AT FIRST ASSIGNED TO LEPIDOCYCLINA (N.) ISOLEPIDINOIDES}

This species is known in the present collection from random thin sections only. Fortunately, one is a well-oriented vertical section and another a very slightly oblique horizontal section.

This species is characterized by open, rectangular lateral chambers having very thin roofs and floors.

Detailed measurements from these two thin sections follow:

Vertical section

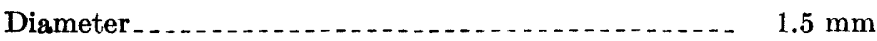

Flange width..... $0.12 \mathrm{~mm}$

Thickness through center .................... $0.8 \mathrm{~mm}$

Embryonic chambers:

Internal length . . . . . . . . . . . . $160 \mu$

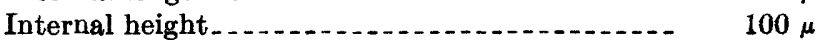

Lateral chambers:

Number on each side of the equatorial layer at 'the center of the test........

Internal height ........

Internal length.

Thickness of floors and roofs.......................

Surface diameter of pillars.

\section{Horizontal section}

Diameter . . . . . . . . .

$1.0 \mathrm{~mm}$

Embryonic chambers:

Diameters of initial chamber. . . . . . . . . . $80 \times 120 \mu$

Diameters of second chamber............... $80 \times 140 \mu$

Distance across both chambers............... $160 \mu$

Equatorial chambers:

Radial diameter............................ $60 \mu$

Tangential diameter......................... $50 \mu$

Locality: Station S-13.

Internally $L$. isolepidinoides is very similar to $L$. parva. The greatest difference is found in the vertical sections: $L$. isolepidinoides has high, open, rectangular lateral chambers and $L$. parva has lower and less open ones, but as there is considerable variation in this feature, it is believed the two species should be combined.

FORM AT FIRST ASSIGNED TO LEPIDOCYCLINA (N.) PARVA, FROY S-34A

Test small, biconvex with a narrow rim; diameter 1.1 to $1.3 \mathrm{~mm}$; thickness 0.5 to $0.6 \mathrm{~mm}$; width of rim 
about $0.1 \mathrm{~mm}$. Surface ornamentation consists of a group of small, apical papillae that have a surface diameter of about $100 \mu$. Between the papillae and on the peripheral margins of the test there are shallow, polygonal pits.

The embryonic chambers are nephrolepidine, but the second chamber hardly embraces the initial one as in Lepidocyclina sensu stricto. The initial chamber has internal diameters of $80 \times 100 \mu$ and the second chamber $50 \times 140 \mu$. The outer wall of the chambers has a thickness of about $20 \mu$. The wall between the two chambers is very thin and strongly curved.

The equatorial chambers have a curved outer wall and pointed inner ends, but are made rhomboid in many specimens by the gentle curve of the outer wall. Normal equatorial chambers are slightly larger near the periphery, and attain radial and tangential diameters of about $40 \mu$.

Measurements of vertical sections

\begin{tabular}{|c|c|c|c|c|}
\hline & 1 & 2 & 3 & 4 \\
\hline $\begin{array}{l}\text { Diameter (mm) } \\
\text { Thickness }(\mathrm{mm}) \\
\text { Lateral chambers on each side of equatorial layer (no.) } \\
\text { Embryonic chambers: } \\
\text { Internal length }(\mu) \\
\text { Internal height }(\mu) \\
\text { Equatorial layer: } \\
\text { Height at center }(\mu) \\
\text { Height at periphery }(\mu) \\
\text { Lateral chambers: } \\
\text { Internal length }(\mu) \\
\quad \text { Internal height }(\mu) \\
\text { Thickness of floors and roofs }(\mu) \\
\text { Surface diameter of pillars }(\mu)\end{array}$ & \begin{tabular}{r|}
1.1 \\
0.5 \\
5 \\
120 \\
80 \\
40 \\
80 \\
100 \\
40 \\
15 \\
60
\end{tabular} & $\begin{array}{r}1.3 \\
0.6 \\
6 \\
80 \\
60 \\
60 \\
90 \\
80-140 \\
40 \\
15 \\
40-80\end{array}$ & $\begin{array}{r}1.2 \\
0.6 \\
6 \\
115 \\
80 \\
60 \\
80 \\
80 \\
30 \\
10 \\
40\end{array}$ & $\begin{array}{r}1.4 \\
0.56 \\
6 \\
160 \\
100 \\
25 \\
40 \\
120 \\
25 \\
10 \\
40\end{array}$ \\
\hline
\end{tabular}

FORM AT FIRST ASSIGNED TO A NEW SPECIES, FROM S-34A

Test small, with a lenticular central portion which is surrounded by a narrow brim. Surface ornamentation, a slightly raised mesh of clear shell material with small papillae at the ridge intersections, except at the outer edge of the brim where the outlines of the equatorial chambers form the surface sculpture. The diameter is 2.0 to $2.6 \mathrm{~mm}$; the thickness 0.66 to $0.78 \mathrm{~mm}$; and the width of the brim 0.3 to $0.4 \mathrm{~mm}$.

The embryonic chambers are nephrolepidine. The initial chamber has internal diameters of $70 \times 140 \mu$ and the second chamber $80 \times 180 \mu$. The internal distance across both chambers is $160 \mu$. The thickness of the outer wall is $25 \mu$. The wall between the two chambers is thin and slightly curved.

There are three kinds of equatorial chambers: those at the center are rhombic, those of the middle area have curved outer walls and pointed inner ends, and those at the periphery are spatulate. The chambers near the center have radial and tangential diameters of about $50 \mu$, those of the middle area have radial diameters of about $60 \mu$ and tangential diameters of about $55 \mu$ and those of the peripheral area radial diameters of about $65 \mu$ and tangentisl diameters of about $40 \mu$.

Measurements of vertical sections

\begin{tabular}{l|r|r|r}
\hline & 1 & 2 & \multicolumn{1}{|c|}{3} \\
\hline Diameter (mm) & 2.6 & 2.2 & 2.0 \\
Thickness (mm) & 0.78 & 0.66 & 0.7 \\
Lateral chambers on each side of equatorial layer $(\mathrm{no})$. & 8 & 8 & 8 \\
Embryonic chambers: & 180 & 180 & 180 \\
Internal length $(\mu)$ & 100 & 100 \\
Internal height $(\mu)$ & 20 & 20 & 25 \\
Equatorial layer: & 60 & 40 & 60 \\
Height at center $(\mu)$ & 120 & $80-140$ & $80-140$ \\
Height at periphery $(\mu)$ & $20-35$ & 20 \\
Lateral chambers: & 20 & 15 & 15 \\
Internal length $(\mu)$ & 80 & 80 & 60 \\
Internal height $(\mu)$ \\
Thickness of floors and roofs $(\mu)$ \\
Surface diameter of pillars $(\mu)$ \\
\hline
\end{tabular}

In addition to the stations mentioned ( $\mathrm{S}-13, \mathrm{~S}-25$ and $\mathrm{S}-34 \mathrm{a})$ specimens referred to this snecies occur at S-17, S-26, S-31 and S-36.

\section{Lepidocyclina (Nephrolepidina) sumatrensis (Brady)}

Plate 10, figures 7-10; plate 11, figures 4, 5

1875. Orbitoides sumatrensis Brady, Geol. Mar., vol. 2, p. 536, pl. 14, figs. 3a-b.

1899. Orbitoides (Lepidocyclina) sumatrensis Brady. Newton and Holland, Ann. and Mag. Nat. Histor:, ser. 7, pp. 259261, pl. 10, figs. 7-11 (probably not fi $\%$ 12).

1928. Lepidocyclina (Nephrolepidina) sumatrensis (Brady). van der Vlerk, Eclog. Geol. Helv., vol. 21, pp. 203-204, fig. 26. 1939 Lepidocyclina sumatrensis (Brady). Caudri, Geol. Mijn. Gen. v. Ned. en Kol., Verh., geol. ser., vol. 12, pp. 185-197, 243, 247, 250, 251, pl. 7, figs. 38, 39 (references and synonymy).

Test small with a strongly inflated central area surrounded by a thin, delicate brim; a snecimen with a diameter of $3.6 \mathrm{~mm}$ has a central area with a diameter of $2.3 \mathrm{~mm}$ and a brim $0.7 \mathrm{~mm}$ wide; arother specimen with a diameter of $4.0 \mathrm{~mm}$ has a central area with a diameter of $2.1 \mathrm{~mm}$ and a brim $0.84 \mathrm{~mm}$ wide. The test is $1.74 \mathrm{~mm}$ thick at the center and $0.1 \mathrm{~mm}$ thick at the brim. About 8 papillae are distributed over the flattened apex of the central, inflated area. Between the papillae there is a faint polygonal mesh representing the outlines of lateral chambers. The central inflated area adjacent to the brim is unornamented. The brim has a faint rhombic mesh representing the walls of equatorial chambers that is best seen when the specimen is wet.

The embryonic chambers are nephrolepidine. The smaller chamber has internal diameters of $180 \times 240 \mu$, and the larger chamber of $124 \times 320 \mu$, The internal distance across both chambers is $320 \mu$. The outer wall of the embryonic chambers is about $40 \mu$ thick. There are several periembryonic chambers which virtually surround the embryonic chambers. The largest periembryonic chambers have internal diameters of $160 \times 60 \mu$. The height of the embryonic chambers in vertical sections is about $140 \mu$. 
The equatorial chambers are short spatulate, of nearly uniform size, and have radial and tangential diameters of about 60 and $40 \mu$ respectively. There is little change in size from the center to the periphery of the test. The equatorial layer has a central height of about $80 \mu$ and a peripheral height of about $100 \mu$, both measurements including the floors and roofs.

There are 14 open lateral chambers arranged in very regular tiers on each side of the equatorial layer at the center of the test, and the number in each tier decreases regularly toward the brim. The brim is not covered by lateral chambers. Lateral chambers at the periphery and over the center have a length of 180 to $220 \mu$ and a height of 45 to $50 \mu$. The tiers of lateral chambers taper regularly toward the center of the test.

Strong pillars are irregularly distributed in vertical sections. These pillars have surface diameters of 140 to $420 \mu$, the larger ones occurring in the central area. The pillars taper regularly and sharply toward the equatorial layer.

Localities: Stations S-3 and S-30, rare.

Discussion.-Miss Caudri (1939, pp. 185-197, 243, $247,250,251$, pl. 7 , figs. 38,39 ) has presented an excellent summary of the knowledge of this species and greatly reduced the confusion caused by Brady's incomplete original description. The specimens from Saipan have both external and internal characters typical of specimens assigned at present to this species, leaving no doubt of their identification.

L. (Nephrolepidina) sumatrensis has been reported from the upper portion of Tertiary " $\mathrm{e}$ " and the lower portion of Tertiary " $f$ ". The association of this species with Spiroclypeus tidoenganensis on Saipan indicates that the age here is Tertiary "e."

Lepidocyclina (Nephrolepidina) verbeeki Newton and Holland Plate 11, figures 6-14; plate 12, figures 7, 12, 13

1899. Orbitoides (Lepidocyclina) verbeeki Newton and Holland, Ann. and Mag. Nat. History, ser. 7, vol. 3, pp. 257-259, pl. 9, figs. 7-11; pl. 10, fig. 1 .

1930. Lepidocyclina (Nephrolepidina) verbeeki Newton and Holland. Yabe and Hanzawa, Tohoku Imp. Univ., Sci. Rept., ser. 2 (Geol.) vol. 14, pp. 26, 27, pl. 1, figs. 1, 2; pl. 2, figs. 1,2 ; pl. 3 , figs. $1-4$; pl. 4 , figs. $1-3$; pl. 8 , figs. 2 , 3 ; pl. 11 , fig. 1.

1943. Lepidocyclina (Nephrolepidina) verbeeki Newton and Holland. Hanzawa, Jour. Geol. Soc. Japan, vol. 50, pp. 129, 130, pl. 9, figs. 1, 2.

- The test has an inflated central area surrounded by a relatively wide flat rim. The diameter of the test is 4.0 to $4.4 \mathrm{~mm}$; the inflated portion has a diameter of 2.5 to $2.9 \mathrm{~mm}$; the fully developed rim is about $1 \mathrm{~mm}$ wide; and the test is 1.6 to $1.7 \mathrm{~mm}$ thick. The surface ornamentation was not observed but probably papillae would be irregularly scattered over the inflated portion, with none on the flange.
The embryonic apparatus was seen only in a s'ightly tangential vertical section. The embryonic apparatus is nephrolepidine and is about $320 \mu$ long. The thi $\%$ kness of the outer wall is about $20 \mu$, and the partition between the chambers is very thin.

Equatorial chambers were seen in two tangential horizontal sections. These chambers are rhombic, witn radial diameters of about $60 \mu$ and tangential diameters of about $45 \mu$. The height of the equatorial layer near the center is about $40 \mu$, and near the peripher: may be as much as $400 \mu$.

The lateral chambers are rectangular, oper. and arranged in regular tiers. There are 16 to 18 chambers to a tier on each side of the equatorial layer. The lateral chambers over the central area of the test and at the periphery have a length of 140 to $240 \mu$, and average $200 \mu$. The height of these lateral chambers is 30 to $40 \mu$, and the thickness of the roofs and floors is 15 to $18 \mu$.

Pillars are irregularly distributed and of various sizes. Some of these have a surface diameter of $140 \mu$, but others may have a surface diameter of as much as $500 \mu$. The pillars taper sharply toward the equatorial layer.

Localities: Station S-33a, common; station S-33bc, rare; station S-33c, abundant.

Random thin sections from station S-33a that apparently represent this same species may be deseribed as follows:

The test has an inflated central part bounded by a narrow rim. The diameter of the test is 3.2 to 3.96 $\mathrm{mm}$; the inflated portion has a diameter of about 2.8 $\mathrm{mm}$; the rim has a width of 0.3 to $0.4 \mathrm{~mm}$; and the thickness through the center is 1.36 to $1.6 \mathrm{~mm}$.

In a tangential equatorial section the embryonic apparatus is nephrolepidine, and has a length of $220 \mu$. The initial chamber has internal diameters of $120 \times 160$ $\mu$ and the second chamber has diameters of $80 \times 160 \mu$. The thickness of the outer wall is about $20^{\circ} \mu$.

The equatorial chambers are rhombic, and have radial and tangential diameters of about $60 \mu$. The equatorial chambers at the center of the test lave a height of 20 to $40 \mu$, and a height at the periphery of 100 to $120 \mu$.

The lateral chambers are rectangular, oper, and arranged in regular tiers. There are 15 to 16 chambers to a tier on each side of the equatorial layer. Chambers over the center and at the periphery have a lensth of 140 to $200 \mu$, a height of 30 to $40 \mu$, and floors and roofs about $20 \mu$ thick.

Pillars are irregularly distributed and have surface diameters of 260 to $300 \mu$.

Recently, Hanzawa (1943, pp. 129, 130) has indicated that $L$. (Nephrolepidina) verbeeki and $L$. (N.) nipponica 
are very similar. $L .(N$.) verbeeki is normally larger and possesses thicker pillars. The equatorial chambers of $L$. (N.) verbeeki are rhombic, whereas those of $L$. $(N$.) nipponica are spatulate.

$L$. (N.) sondaica Yabe and Hanzawa (1929, p. 172) closely resembles $L$. (N.) verbeeki, and, in fact, Yabe and Hanzawa based their $L$. $(N$.) sondaica on specimens originally referred to $L$. $(N$.) verbeeki. The specimens were smaller and lacked the rim. The writer does not consider these differences to be of specific significance and that Yabe and Hanzawa were correct in their original assignment of the specimens to $L$. $(N$.) verbeeki.

Subgenus EULEPIDINA H. Douvillé, 1911

Lepidocyclina (Eulepidina) bridgei Cole, n. sp. ${ }^{6}$

Plate 9, figures 2-4, 13, 14, 19-21

The test is small and has a prominent umbonal area surrounded by a wide thin brim. There are three types of umbo in specimens assigned to this species. In the first (pl. 9, fig. 3) the central area is compressed and lenticular, in the second (pl. 9, fig. 4) it is evenly lenticular and in the third (pl. 9, fig. 2) it is inflated. The compressed type has an umbo about $1 \mathrm{~mm}$ across and a thickness through the center of about $0.4 \mathrm{~mm}$. The evenly lenticular form has an umbo $2.8 \mathrm{~mm}$ across and a thickness of about $1.0 \mathrm{~mm}$. The inflated type has an umbo 1.6 to $2 \mathrm{~mm}$ across and a thickness of 1.0 to $1.24 \mathrm{~mm}$. On this last type the brim has a width of about $1.0 \mathrm{~mm}$. The total diameter of specimens of this type is 3.7 to $4.2 \mathrm{~mm}$. Minute papillae between very shallow polygonal-shaped pits occur on the central area and for a short distance on the brim, beyond this area a mesh is formed by the vertical walls of the equatorial chambers that are not covered by lateral chambers on the outer margin of the brim.

Measurements of vertical sections

\begin{tabular}{|c|c|c|c|c|}
\hline \multirow[t]{2}{*}{. } & \multicolumn{4}{|c|}{ Type of umbo } \\
\hline & $\begin{array}{c}\text { Com- } \\
\text { pressed }\end{array}$ & $\begin{array}{c}\text { Evenly } \\
\text { lenticu- } \\
\text { lar }\end{array}$ & Inflate & \\
\hline $\begin{array}{l}\text { Umbonal diameter }(\mathrm{mm}) \\
\text { Thickness }(\mathrm{mm}) \\
\text { Embryonic chambers: } \\
\text { Length }(\mu) \\
\text { Height }(\mu) \\
\text { Thickness of outer wall }(\mu) \\
\text { Lateral chambers on each side of embryonic } \\
\text { chambers at center (no.) } \\
\text { Lateral chambers: } \\
\text { Length }(\mu) \\
\text { Height }(\mu) \\
\text { Thickness of floors and roofs }(\mu) \\
\text { Surface diameter of pillars }(\mu) \\
\text { Height of equatorial chambers }(\mu)\end{array}$ & $\begin{array}{r}1.0 \\
0.42 \\
720 \\
200 \\
40 \\
2 \\
100-120 \\
20 \\
20 \\
60\end{array}$ & $\begin{array}{r}2.8 \\
1.0 \\
760 \\
200 \\
60 \\
7 \\
120-160 \\
20 \\
20-30 \\
\hdashline 60\end{array}$ & $\begin{array}{r}1.6 \\
1.0 \\
1,200 \\
740 \\
80 \\
2 \\
120-200 \\
20 \\
20 \\
80 \\
80\end{array}$ & $\begin{array}{r}1.24 \\
1.98 \\
1,480 \\
880 \\
60 \\
3 \\
100-220 \\
30 \\
20 \\
60 \\
100\end{array}$ \\
\hline
\end{tabular}

1 All measurements of chambers are internal.

${ }^{5}$ This species is similar to, if not identical with, $L$. $(E$.$) badjirraensis Crespin (1952,$ pp. 29,$30 ;$ pl. 6 , figs. $1,2,5 ;$ pl. 7 , figs. $1,2,4 ; \mathrm{pl}$. 8, figs. 1-5), from the Miocene " $\mathrm{e}$ "
of Australia, published while the present report was in press.
Measurements of horizontal sections

\begin{tabular}{|c|c|c|}
\hline & \multicolumn{2}{|c|}{ Type of umbo } \\
\hline & Compressed & Inflated \\
\hline $\begin{array}{l}\text { Embryonic chambers: } \\
\text { Distance across both ehambers from point of attach- } \\
\text { ment of internal chamber }(\mu) \\
\text { Distance across chambers at right angles to the first } \\
\text { measurement }(\mu) \\
\text { Diameters of internal chamber }(\mu) \\
\text { Thickness of outer wall }(\mu) \\
\text { Thickness of wall of internal chamber }(\mu) \\
\text { Equatorial chambers: } \\
\text { Shape } \\
\text { Radial diameter }(\mu) \\
\text { Tangential diameter }(\mu)\end{array}$ & \begin{tabular}{|r|}
750 \\
840 \\
$460 \times 480$ \\
90 \\
20 \\
\\
Spatulate \\
$90-120$ \\
$70-90$
\end{tabular} & $\begin{array}{r}800 \\
940 \\
500 \times 540 \\
100 \\
40 \\
\\
\text { Spatulate } \\
140 \\
60-80\end{array}$ \\
\hline
\end{tabular}

Locality: Station S-34a, common.

Type material: Holotype (uncut sp cimen); paratypes, 4 vertical sections and 2 equatorial sections: U.S.N.M. 560274a-g.

This specie is named in honor of Dr. Josiah Bridge who collected the material used in this report.

This species belongs in the Lepidocyclina (Eulepidina) formosa group, but the large, thick-walled embryonic apparatus and the small number of lateral chambers differentiates it from other Indo-Pacific species although there is a resemblance to specimens from Java figured by Scheffen (1932, pp. 32, 33, pl. 6, figs. 1-3) under the name Lepidocyclina crassata Cushman that also possess a relatively large, thick-walled embryonic apparatus.

Lepidocyclina (Eulepidina) formosa Schlumberger

Plate 7, figures 4, 5; plate 10, figures 1-6

1902. Lepidocyclina formosa Schlumberger, Samm. Geol. Reichs Mus., Leiden, ser. 1, vol. 6, p. 251, pl. 7, figs. 1-3.

Megalospheric form.-Typical specimens have a strongly inflatéd, nearly globular central area surrounded by a narrow rim. These specimens have a diameter of 9 to $12 \mathrm{~mm}$, of which about $5.7 \mathrm{~mm}$ comprices the central inflated area. The thickness through the center is 3.5 to $4.5 \mathrm{~mm}$. The rim is thin and has a thickness of about $0.5 \mathrm{~mm}$. Unweatbered specimens are unornamented except for a polygonal mesh of clear shell material that is flush with the surface of the test. Weathered specimens have conspicuous pits that are bounded by walls of clear shell mater:ql, polygonally arranged. These pits are larger and more conspicuous in the central area.

The equatorial chambers are short spatulate and have the radial and tangential diameters nerrly the same. No pillars are present. 
Measurements of vertical sections

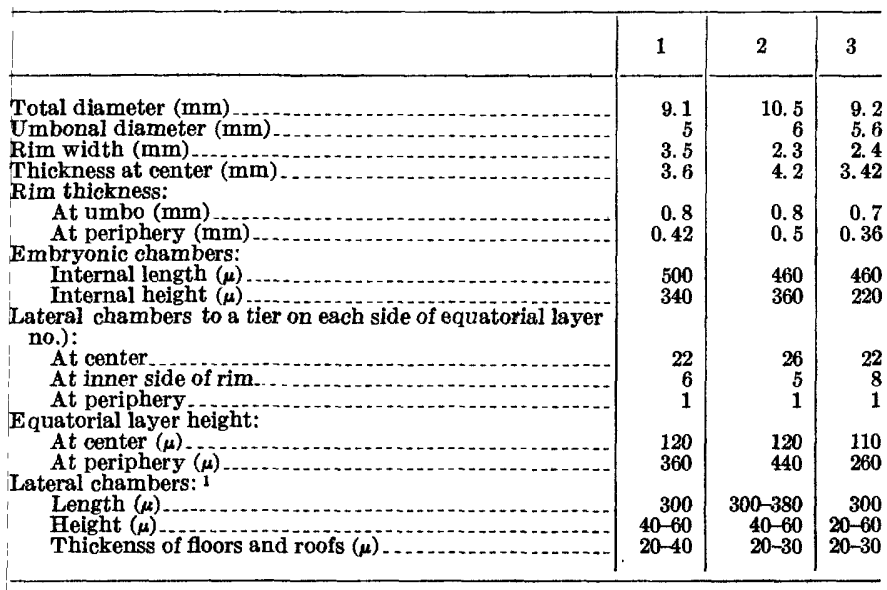

1 At periphery over center.

Measurements of equatorial sections

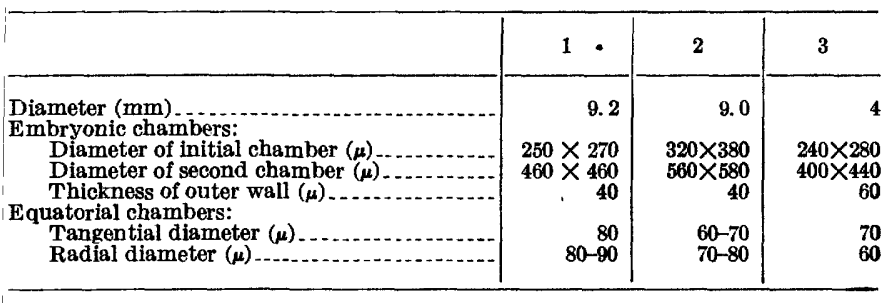

Microspheric form.-The test is large and has a clearly differentiated umbo surrounded by a wide flat or slightly undulating rim. The largest specimen found is $29 \mathrm{~mm}$ across; the thickness through the center is $4.2 \mathrm{~mm}$; the diameter of the umbo is 7 to $8 \mathrm{~mm}$; the rim adjacent to the umbo is $2.3 \mathrm{~mm}$ thick and at the periphery $1.2 \mathrm{~mm}$ thick. Unweathered specimens have a flush, polygonal mesh of clear shell material the boundaries of which radiate from small round masses of clear shell material. The clear areas at the angles of the polygons have diameters of about $60 \mu$. On slightly weathered surfaces the cloudy shell material within the polygonal areas weathers more rapidly, producing shallow pits.

Vertical thin sections show about 35 lateral chambers arranged in regular tiers on each side of the equatorial layer at the center of the test. In the rim at the juncture with the umbonal area there are about 20 lateral chambers to a tier on each side of the equatorial layer, and at the periphery the number of lateral chambers is reduced to about 5 on each side of the equatorial layer.

The lateral chambers have distinct, open, rectangular cavities except those near the equatorial layer, which are appressed. Lateral chambers at the periphery and over the center have lengths of 220 to $320 \mu$, and internal heights of about $40 \mu$. The lateral chambers gradually and regularly decrease in size toward the equatorial layer. Roofs and floors have a thickness of about $20 \mu$. True pillars are not present, but pillarlike struc- tures (pl. 10, fig. 1) representing the chamber walls were observed.

The equatorial layer is thin (about $80 \mu$ high) at the center of the test, and gradually increases to $440 \mu$ at the periphery. These measurements include roof and floor thickness.

The equatorial chambers are short spatulate and have radial and tangential diameters of about 240 and $140 \mu$, respectively.

Locality: Station S-25, megalospheric form, abundant; microspheric form, rare.

Jones and Chapman $(1900$, p. 252) described Lepidocyclina murrayana on the basis of a thin sectior. cut from limestones from Christmas Island. Nuttall (1926, p. 29) restudied the orbitoids from Christmas Island, and stated:

In my opinion, from the data furnished by the single equatorial section, it is not improbable that the species ( $L$. murrayana) is identical with $L$. formosa Schlumberger.

As $L$. murrayana (1900) has priority over $L$. formosa (1902), the case should be resolved in favor of that name despite the fact that the name formosa has become firmly entrenched in the literature.

Crespin (1938, p. 11) used $L$. murrayana in preference to $L$. formosa in the description of certain lower Mic sene species from the Ok Ti river, Papua, but, Hanzawa $(1942$, p. 122) is of the opinion that the name L. formosa should be retained for the present.

As it has not been demonstrated by clear and conclusive proof that the imperfectly described $L$. murray$a n a$ and the well illustrated $L$. formosa are the same species, both names must be retained. Therefore, $L$. formosa is used here as the specimens from Saipan are certainly the same as the ones illustrated by Schlumberger and others under the name L. formosa.

\section{Lepidocyclina (Eulepidina) gibbosa Yabe}

Plate 8, figures 2-7

1911. Lepidocyclina formosa $\mathrm{H}$. Douvillé, Philippine Jour. Sci., vol. 6, p. 72, pl. D, figs. 2-5 (not Lepidocyclina formosa Schlumberger).

1919. Lepidocyclina (Eulepidina) gibbosa Yabe, Tohoku Imp. Univ., Sci. Rept., ser. 2 (Geol.), vol. 5, No. 2, p. 46, pl. 6, figs. 3, 4c, $7 \mathrm{c}$.

The test has an inflated central part surrounded by a relatively wide, very thin, rim in both the meralospheric and microspheric forms; in the megalospheric form the central inflated area is 2.2 to $3.3 \mathrm{~mm}$ across, and the bordering rim about $1 \mathrm{~mm}$ wide. In the microspheric form the central inflated area is about $3.8 \mathrm{~mm}$ across, and the bordering rim about $2 \mathrm{~mm}$ wide. The umbonal part of the test is covered with polygonal pits that average $0.24 \mathrm{~mm}$ in diameter. The rim, when wet, reveals the outline of equatorial chambers, with esp ecial clarity near the periphery. 
Measurements of vertical sections

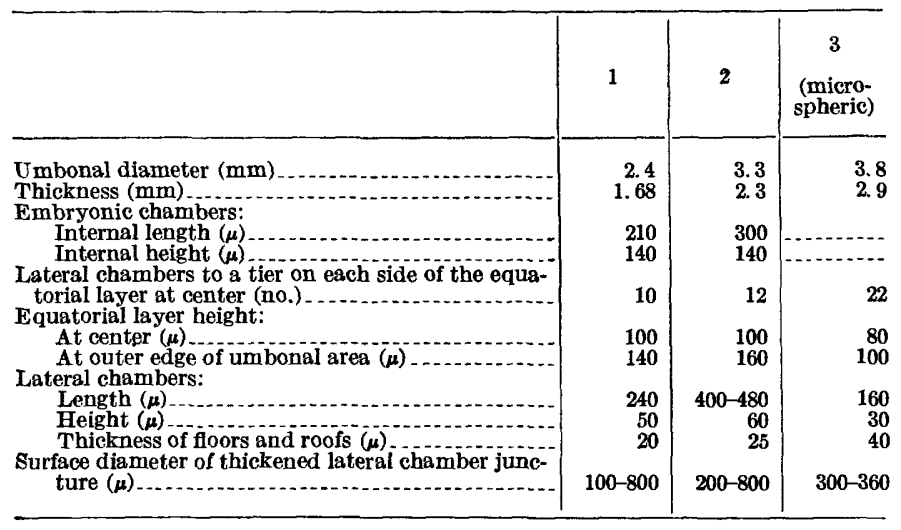

Measurements of equatorial sections

\begin{tabular}{|c|c|c|}
\hline & 1 & 2 \\
\hline $\begin{array}{l}\text { Diameter (mm) } \\
\text { Embryonic chambers: } \\
\text { Diameter of initial chamber }(\mu) \\
\text { Diameter of second chamber }(\mu) \\
\text { Thickness of outer wall }(\mu) \\
\text { Equatorial chambers: } \\
\text { Tangential diameter }(\mu) \\
\quad \text { Radial diameter }(\mu)\end{array}$ & $\begin{array}{r}3.5+ \\
140 \times 140 \\
220 \times 240 \\
22 \\
50 \\
60\end{array}$ & $\begin{array}{r}3+ \\
100 \times 120 \\
160 \times 180 \\
22 \\
50 \\
60\end{array}$ \\
\hline
\end{tabular}

The lateral chambers are arranged in regular tiers between thickened areas, which represent the junction of the lateral chambers. In vertical sections these thickened areas resemble pillars but the external surface is devoid of papillae, and sections through the lateral chambers parallel to the equatorial plane do not show typical pillar structure. The chambers have open cavities and relatively thick floors and roofs.

The equatorial chambers are short spatulate and small at the center, becoming hexagonal and progressively larger toward the periphery.

Localities: Station S-34a, common; S-36, rare.

Remarks.-H. Douvillé (1911, p. 72, pl. D, fig. 3) figures a specimen under the name Lepidocyclina formosa Schlumberger from Guilaguila (Cebu, no. 278), which is externally very similar to the specimens from Saipan. The specimen from the Phillippines is larger, and has surface pits that are slightly smaller and more irregular in outline.

Yabe $(1919$, p. 46) described specimens from Cebu under the name $L$. gibbosa and states:

As L. formosa of Douville from the Philippines seems to me to be distinct from the type of $L$. formosa Schlumberger I think it is better to give a new name to the present species.

Later, van der Vlerk (1928a, table 3) proposes that the name $L$. gibbosa be suppressed, apparently considering Yabe's specimens within limits of $L$. formosa.

The specimens from Saipan have the thickened wall surrounding the lateral chambers, which is the outstanding characteristic of $L$. gibbosa as described by Yabe. As specimens of $L$. formosa in the present collection do not show this feature, the name gibbosa is applied to those specimens from Sripan that have this thickened lateral chamber junctur?.

Lepidocyclina (Eulepidina) planata Oppenoorth

Plate 7, figures 1-3

1909. Lepidocyclina formosa Provale, Rivista Ital. Pal., vol. 15, p. 67, pl. 2, figs. 1-2, not fig. 3, (not $L$. formosa Schlumberger, 1902).

1918. Lepidocyclina (Eulepidina) planata Oppenoorth, Geol. Mijn. Gen. v. Ned. en Kol., Verh., geol. ser., vol. 2, p. 254, pl. 8, fig. 7-10.

1925. Lepidocyclina planata Oppenoorth. van der Vlerk, Nederlaudsche Akad. Wetens. Meded.,no. 3, pp. 26-27, pl. 2, figs. 12,13 ; pl. 5 , fig. 43 .

1928. Lepidocyclina (Eulepidina) planata Openoorth. van der Vlerk, Eclog. Geol. Helv., vol. 21, p. 201, pl. 9, fig. 8a-c 1930. Lepidocyclina (Eulepidina) planata Opp moorth. Hanzawa Tohoku Imp. Univ., Sci. Rept., ser. 2 (Geol.), vol. 14, p. 91, pl. 26, figs. 10-11.

Associated with $L$. (E.) formosa Schlumberger are a few specimens that have strongly selliform tests and a low, indistinct umbo. The surface resembles that of $L$. formosa. At first, these specimens were considered to be one end of a possible series of $L$. formosa, but vertical and horizontal thin sections revealed a much larger and thicker-walled embryonic apparatus.

The test is 9.5 to $12.5 \mathrm{~mm}$ across and 1.5 to $2 \mathrm{~mm}$ thick through the center. A low indistinct umbo about $2.2 \mathrm{~mm}$ in diameter is surrounted by a rim of 4.5 to $5.5 \mathrm{~mm}$ wide. The rim is abont $1.3 \mathrm{~mm}$ thick where it joins the umbo and about $0.5 \mathrm{~mm}$ thick at the periphery.

The embryonic chambers are eulepidine. The initial chamber has diameters of $480 \times 800 \mu$ and the second chamber diameters of $860 \times 1160 \mu$. Tr e internal height of the embryonic chambers is $460 \mu$. The outer wall has a thickness of about $80 \mu$.

The equatorial chambers are short spatulate and have radial diameters of about $100 \mu$ and tanzential diameters of 80 to $90 \mu$. The equatorial layer has a height of about $200 \mu$ at the center of the test ard of about $400 \mu$ at the periphery.

At the center of the test about 11 lateral chambers are arranged in regular tiers on each side of the embryonic chambers. At the inner part of the rim there are 7 lateral chambers and at the periphery a single layer of lateral chambers on each side of the equatorial layer.

The lateral chambers are rectangular and open, and are about $200 \mu$ long and $40 \mu$ high. The floors and roofs are 20 to $30 \mu$ thick. Pillars are absent.

Locality: Station S-25, rare.

Discussion.-The measurements of these specimens from Saipan are similar to those given by van der Vlerk $(1928 \mathrm{~b}$, table A) for $L$. (E.) planata Oppenoorth. 
Provale considered similar specimens from Borneo to represent $L$. formosa before Oppenoorth created the specific name planata.

The relationship and association of $L$. formosa and $L$. planata is the same as that of $L$. favosa and $L$. undosa from the American Oligocene. Probably they all represent one species, with wide variation in form and distribution.

\section{Lepidocyclina (Eulepidina) saipanensis Cole, n. sp. \\ Plate 8, figures 8-15}

Test thickest at the center with a small umbo from which the thickness gradually decreases toward the periphery so that a wide brim surrounds the umbo. Except for a few low papillae on the central portion of the test and the outlines of equatorial chambers, which appear as a mesh near the periphery, the surface is unornamented.

The embryonic chambers are eulepidine. A specimen $2.8 \mathrm{~mm}$ in diameter has an initjal chamber that has internal diameters of $150 \times 160 \mu$ that is completely surrounded by a second chamber having diameters of $260 \times 280 \mu$. The outer wall is thick, about $40 \mu$ wide, and the wall of the initial chamber about $20 \mu$ wide. A larger specimen more than $4 \mathrm{~mm}$ in diameter has an initial chamber whose internal diameters are $140 \times 160 \mu$, and is completely surrounded by a second chamber whose diameters are $240 \times 250 \mu$.

The equatorial chambers are short, spatulate, gradually increasing in size from the center to the periphery. Near the periphery the chambers have a radial diameter of $80 \mu$ and a tangential diameter of $60 \mu$.

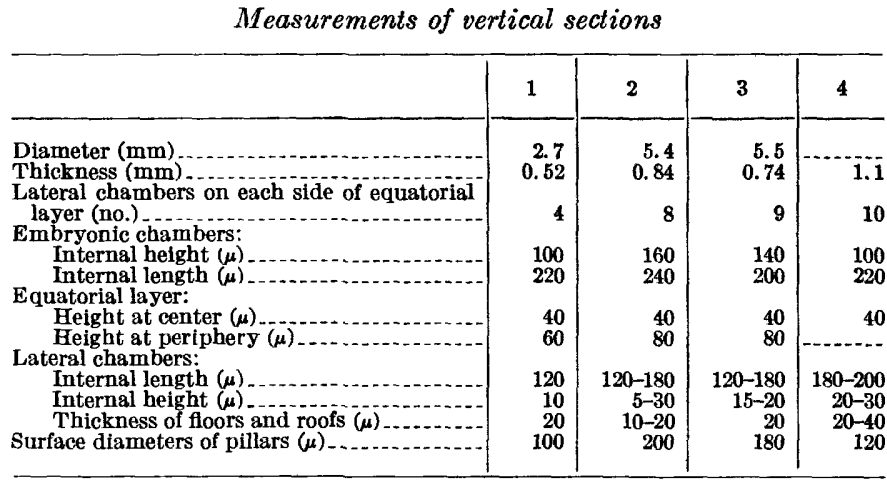

The chamber opening of the lateral chambers is slitlike between thick roofs and floors. The lateral chambers are not arranged in regular tiers. The pillars are scarce and seen only in the central part of the specimens in vertical section.

Locality: Station S-34a, common.

Type material: Holotype (uncut specimen); paratype, 4 vertical sections and 2 equatorial sections: U.S.N.M. 560275a-g.
Remarks.-These specimens were first identified as L. (Eulepidina) dilatata Michelotti, which they closely resemble. However, $L$. (E.) dilatata is much larger and has papillae over the entire surface. As the specimens from Saipan are not only much smaller, but also have the papillae concentrated in the central area of the test, it was decided that the present form is sufficiently different to warrant describing it as a new species.

Family DISCOCYCLINIDAE Vaughan and Cole, $194 ?$

Genus DISCOCYCLINA Gümbel, 1870

\section{Discocyclina sp. A \\ Plate 12, figure 3}

Asano (1939a, pl. 27, fig. 2) illustrates a vertical section identified as Discocyclina javana (Verbeek), which is similar to one made from a sample obtained at station S-24.

The present material does not permit further identification.

\section{Discocyclina sp. B \\ Plate 12, figure 4}

A vertical section, broken at one end, was discovered in a sample from station $\mathrm{S}-24$. This specimen has a thickness through the center of $1.28 \mathrm{~mm}$ and a semidiameter of $1.4 \mathrm{~mm}$ (or a diameter of $2.8 \mathrm{~mm}$ ). The abrupt ending of the unbroken peripheral side indicates the former presence of a keel.

Van der Vlerk (1929, fig. 38c) figures a vertical section as Orthophragmina (Discocyclina) dispansa (Sowerby), which has a resemblance to the specimen from $\&$ qipan. The specimen from Borneo has a thickness through the center of $1.5 \mathrm{~mm}$ and a diameter of $4.3 \mathrm{~mm}$.

\section{Genus ASTEROCYCLINA Gümbel, 1870}

Asterocyclina sp.

Plate 12, figures 1, 2; plate 15, figures 8,9

Two fragments of vertical sections from station S-24 and two incomplete oblique horizontal sections from station S-18 serve to demonstrate the occurrence of this genus in the Eocene beds of Saipan. Fairly numerous sections of the genus were encountered in thin sections but none are sufficiently well orier ted or complete for specific identification.

\section{Family MIOGYPSINIDAE Tan, 1937 Genus MIOGYPSINA Sacco, 1893}

\section{Miogypsina (Miogypsina) inflata Yabe and Hanzara \\ Plate 13, figures 12-14}

1930. Miogypsina (s. s.) inflata Yabe and Hanzawa, Tohołu Imp. Univ., Sci. Rept., ser. 2 (Geol.), vol. 14, p. 33, pl. 3, fig. 6; pl. 10, fig. 7?; pl. 12, figs. 6, 7; pl. 14, fig. 6 ; pl. 16, fig. 9 .

Several random sections of this species are in the present collection, but none of them adequately exposes the equatorial plane. The vertical sections indieate 
lengths of 1.6 to $1.84 \mathrm{~mm}$ and maximum thicknesses of 0.6 to $0.8 \mathrm{~mm}$.

There are 4 to 5 layers of lateral chambers on each side of the equatorial layer. The roofs and floors of these lateral chambers are so strongly convex that some chambers seem to be hemispherical. Numerous pillars that have surface diameters of as much as $80 \mu$ are scattered throughout the vertical sections.

The embryonic chambers are apparently bilocular, although the sections available normally intersect only one of the embryonic chambers. Such a chamber has an internal diameter of about $130 \mu$ and is bounded by a wall about $40 \mu$ thick.

The equatorial layer has an internal height of about $80 \mu$.

Localities: Stations S-11 and S-33bc, common.

This species was described from random sections made from a collection from Formosa. The original description and illustrations by Yabe and Hanzawa are incomplete because many of the features of this species could not be observed in the sections available.

However, comparison of the random sections of the specimens from Saipan with the illustrations of the types reveals internal features sufficiently similar and diagnostic to establish the identification.

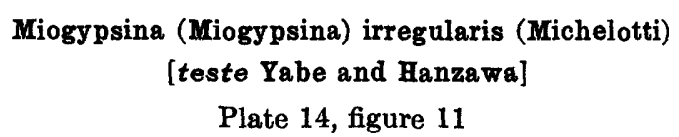

Plate 14, figure 11

1930. Miogypsina (s.s.) irregularis Yabe and Hanzawa, Tohoku Imp. Univ., Sci. Rept., ser. 2 (Geol.), vol. 14, p. 35, pl. 11, fig. 11 ; pl. 12, figs. $2-5$.

A few random thin sections from stations S-33a and S-33c reveal specimens like those figured by Yabe and Hanzawa from Formosa under the name $M$. (M.) irregularis (Michelotti). The illustration of the specimen from Saipan should be compared with plate 11, fig. 11 of Yabe and Hanzawa. It is extremely doubtful that specimens from the Pacific area belong to a European species, but the material at hand is insufficient for identification.

Localities: Station S-33a, rare; stations S-33c, S-36, rare.

Miogypsina (Miogypsina) mamillata Yabe and Hanzawa

Plate 13, figure 16

1930. Miogypsina (s.s.) mamillata Yabe and Hanzawa, Tohoku Imp. Univ., Sei Rept., ser. 2 (Geol.), vol. 14, p. 34, pl. 1, fig. 11 ; pl. 3, figs. 7, 8; pl. 4, fig. 6 ; pl. 6, fig. 13 ; pl. 11, figs. 7,8 ; pl. 12, fig. 1 ; pl. 13, fig. 8 .

Poorly oriented sections of a small miogypsinid were found in sections of the material from stations S-11, S-33a, S-33bc and S-33c apparently belong to this species although they do not clearly reveal the specific characters. However, these specimens from Saipan closely resemble specimens from Formosa to which the specific name mamillata has been assignec'.

The type specimens are also unoriented sections, and the species is very imperfectly descrik $9 \mathrm{~d}$.

Genus MIOGYPSINOIDES Yabe and Hanzawa, 1928

Miogypsinoides abunensis (Toblar)

Plate 13, figures 8,9 ; plate 14, figures 9,10

1927. Miogypsina abunensis Tobler, Eclog. Geol. Helv., vol. 20, pp. 323-330, text-figs. 3, 5 .

1929. Miogypsina abunensis Tobler. van der Vlerk, Nederlandsche Akad. Wetens. Meded., Nc. 9, pp. 24, 25, figs. 23, 49a-b.

1929. Miogypsina abunensis Tobler. van der Vlerk and Wennekers, Eclog. Geol. Helv., vol. 22, p. 170, pl. 16, fig. 9.

1936. Conomiogypsinoides ef. abunensis (Tobler). Tan, De Ing. in Ned.-Indie, Jaarg. 3, no. 3, pp. 51, 52, p1. 1, figs. 8-10.

Several megalospheric and one microsnheric random section of a species of Miogypsinoides that has heavy conical pillars were found, at two stations.

The best megalospheric specimen is remresented by a well-oriented vertical section. This specimen has a diameter of $1.8 \mathrm{~mm}$ and a thickness of $1.2 \mathrm{~mm}$.

The embryonic apparatus is bilocular and has a length of $260 \mu$ and a height of $160 \mu$. The equatorial layer near the embryonic chambers has a height of $140 \mu$ and of $180 \mu$ at the periphery. Heavy conical pillars extend from the equatorial layer to the periphery, and their surface diameter is 120 to $14: 0 \mu$. Between the pillars there are fibrous zones whose fibers are parallel to the pillars.

The microspheric specimen is $4.6 \mathrm{~mm}$ in diameter and about $1.6 \mathrm{~mm}$ thick. The heavy pillsrs are slightly more numerous than in the megalospl aric form and the fibrous zones between them are nerrower. Some pillars have a surface diameter of $400 \mu$.

Localities: Stations S-33a and S-33c, common.

Two species of Miogypsinoides witk heavy pillars in lamellate wall structure have been described- $M$. abunensis Tobler and $M$. dehaartii pustulosa Hanzawa (1940, pp. $780-782$, pl. 40, figs. $2-28$; pl. 42 , fig. 13 ). $M$. abunensis is incompletely described and figured, but the specimens from Saipan closely resemble the imperfect figures and descriptions.

\section{Miogypsinoides formosensis Yabe and Hanzawa}

Plate 8, figures 18, 19; plate 13, figures 1-3, 10, 11, 15, 16; plate 14, figure 8

1928. Miogypsina (Miogypsinoides) dehaartii van der Vlerk, var. formosensis Yabe and Hanzawa, Imp. Acad. Japan, Proc., vol. 4, no. 9, p. 534, text-figs. 1a-b.

1930. Miogypsina (Miogypsinoides) dehaartii van der Vlerk, var. formosensis Yabe and Hanzawa, Tohoku Imp. Univ., Sci. Rept., ser. 2 (Geol.), vol. 14, no. 1, pp. 32-33, pl. 3 , figs. 4 , 5 ; pl. 4 , figs. 3,4 ; pl. 7 , f r. 12 ; pl. 9, fig. 9; pl. 11, figs. 1-6, 12. 
1939. Miogypsinoides dehaartii van der Vlerk, var. formosensis Yabe and Hanzawa. Cole, Jour. Paleontology, vol. 13, no. 2, p. 187, pl. 24, figs. 1-7.

1940. Miogypsinoides formosensis Yabe and Hanzawa. Hanzawa, Yabe's Jubilee Pub., p. 776.

Test small, ovate in plan, compressed, and thickest near the center. Surface ornamented by sinall, closely spaced, slightly raised pustules. One matrix-free specimen is $2.08 \mathrm{~mm}$ long and $2.2 \mathrm{~mm}$ wide; another specimen is $1.6 \mathrm{~min}$ long and $0.72 \mathrm{~mm}$ thick.

The embryonic apparatus consists of two subequal chambers surrounded by a coil of about 10 , more or less rectangular chambers, followed by normal rhomboidal equatorial chambers. The initial chamber has diameters of $180 \times 220 \mu$ and the second chamber of about $120 \times 220 \mu$. From the initial edge of the test to the center of the first chamber of the embryonic apparatus is $0.4 \mathrm{~mm}$.

The rhombic equatorial chambers have radial diameters of $180 \mu$ and tangential diameters of about $260 \mu$. In vertical sections the equatorial chambers have an internal height of about $160 \mu$.

The equatorial layer is covered by laminae of shell material apparently without lateral chambers or pillars. The divisions between the laminae are clearly visible.

This description is based on three matrix-free specimens recovered from the material from station S-34a. Random sections of specimens referred to this species are cominon at stations S-11, S-16, S-31, S-33a, S-33bc, S-33c, S-34a, S-34b and S-36.

The species Miogypsina dehaartii was described by van der Vlerk (1924, pp. 429-432, text figs. 1-3). Yabe and Hanzawa (1928, p. 535, text fig. 1) described specimens from Taianryō (Sekihekiryō), Hai-shan Ch'u (formerly Dojosho, Kaizan-gun), Tai-pei Hsien, (formerly Taihoku) prefecture, Formosa, as Miogypsina (Miogypsinoides) dehaartii van der Vlerk, variety formosensis Yabe and Hanzawa. Yabe and Hanzawa (1930) illustrated many randoin sections of specimens that they referred to this variety from several places in Formosa, and included some new illustrations of specimens from the type locality. Cole $(1939$, p. 187 , pl. 24, figs. 1-7) published illustrations of specimens from Guain and from the type locality. The specimens from Guam are larger than those from the type locality, but otherwise similar.

However, some specimens from other localities in Formosa, referred by Yabe and Hanzawa to formosensis, were identical in size as well as in other features with the specimens from Guam (Yabe and Hanzawa, 1928, pl. 4, fig. 3).
Later, Hanzawa (1940, pp. 782, 783, pl. 39, figs. 15-19; pl. 41, figs. 24-26) referred certain specimens from the test well on North Kita-daito-jima (North Borodino Island), to Miogypsinoides bantamensis Tan. These specimens apparently resemble some that ? $\mathrm{T}$ abe and Hanzawa reported from Formosa as $M$. formosensis, and also those from Guam that Cole referred to this species.

Soine specimens from Saipan strongly resemble those from Guam and certainly belong to the rame species as solne of the specimens from Formoss, referred originally to $M$. formosensis by Yabe and J Tanzawa.

However, there are certain differences in the structure of the layers covering the equatorial plane ir the specimens froin Saipan here included in $M$. formosensis. The vertical section of the specimen from station S-34a shows distinct lamellar structure in the layer covering the equatorial plane, but the specimens from stations S-31 and S-34b have the equatorial layer covered by a thick zone of shell material that has indistinct lamellar structure and contains small conical pillarlike objects of darker shell material. Most of the specimens from S-16, S-33a, and S-33bc and S-33c have small but clearly visible vertical canals that extend from the equatorial layer to the surface through the very indistinctly lamellated covering walls.

Topotype's of $M$. formosensis from Sekihekiryô (now Taianryō) in Taihoku (now T'ai-pei Hsien) prefecture, Formosa in the writer's collection have the covering layer coinposed of indistinctly lamellated shell material with sinall, conical, darker pillarlike structures embedded in these walls. However, examination of the photomicrographs of $M$. formosensis by Yabe and Hanzawa (1930) shows two kinds of covering walls in specimens referred to this species. The central snecimen of their plate 4, figure 3 , has an indistinctly lamellated covering wall in which there are small, conical pillars, whereas the specimen shown in plate 7 , figure 12 has vertical canals perforating the covering wall.

Most of the specimens from Saipan are random cross sections and therefore it is impossible to evaluate the differences in the structure of the walls coviring the equatorial plane. At several stations on Seipan specimens of this group are associated with Lepidocyclina (Nephrolepidina) verbeeki Newton and Holland, an association also observed in Formosa, so until the structural features of this species can be studiet in matrix-free specimens, it is believed best to refer all the specimens from Saipan to $M$. formosensis. 


\section{LITERATURE CITED}

Asano, Kiyoshi, 1939a, Limestones of the South Sea Islands under Japanese Mandate: The Jubilee Publication in commemoration of Professor H. Yabe's 60th birthday, vol. 1, pp. 537-550. (Japanese, unedited English translation in library of the U. S. Geological Survey.)

-1939b, Fossils and the stratigraphic succession on Saipan Island: Kagaku (Science), vol. 9, no. 9, pp. 333-335. (Japanese, unedited English translation in library of the U. S. Geological Survey.)

Bryan, E. H., Jr., 1946, Area of Islands in Micronesia: U. S. Commercial Company, Economic Survey of Micronesia, vol. 2, pt. 3, atlas (mimeographed). Microfilm, Library of Congress.

Caudri, C. M. B., 1934, Tertiary Deposits of Soemba, Diss., Leiden, Nat. Mus. Geol. 224 pp., 24 figs., 5 pls., Amsterdam.

- - 1939, Lepidocyclinien von Java: Geol.-mi jnb. genoot. Nederland en Kolonien, Verh., Geol. ser., deel 12, pt. 2, pp. 135-258, 10 pls.

Cloud, P. E., Jr., 1949, Preliminary gazetteer of geographic names for Saipan: Office of the Engineer, GHQ, Far East Command

Cole, W. Storrs, 1939, Large Foraminifera from Guam: Jour. Paleontology, vol. 13, no. 2, pp. 183-189, pls. 23, 24, 1 text fig. - 1945, Larger Foraminifera, in Ladd, H. S., and Hoffmeister, J. E., Geology of Lau, Fiji: Bernice P. Bishop Mus., bull. 181, pp. 272-297, pls. 12-30.

‥ 1950, Larger Foraminifera from the Palau Islands: U. S. Geol. Survey Prof. Paper 221b, pp. 21-31, pls. 5, 6, 1 text fig.

Cole, W. Storrs, and Bermudez, P. J., 1944, New foraminiferal genera from the Cuban Middle Eocene: Bull. Am. Paleontology, vol. 28, no. 133, pp. 331-350, pls. 27-29.

Crespin, Irene, 1938, A lower Miocene limestone from the $\mathrm{Ok} \mathrm{Ti}$ River, Papua: Palaeont. Bull., no. 3, pp. 9-12, pls. 3, 4, Australia, Dept. Interior.

-1943, The stratigraphy of the Tertiary marine rocks in Gippsland, Victoria: Australia Bur. Min. Resources, Geol. and Geophysics, Bull. 9, (Palaeont. Ser., no. 4) pp. 1-101, figs. 1-8.

- 1952, Two new species of Lepidocyclina from Cape Range, Northwestern Australia: Contr. Cushman Found. Foram. Research, vol. 3, pp. 28-31, pls. 6-8.

Douville, Henri, 1905, Les Foraminifères dans le Tertiaire de Borneo: Geol. Soc. France Bull., ser. 4, vol. 5, pp. 435-464, pl. 14, text figs. $1,2$.

___ 1911, Les Foraminifères dans le Tertiaire des Philippines: Philippine Jour. Sci., vol. 6, no. 2, pp. 53-80, pls. A-D, text figs. 1-9.

—_ 1912, Les Foraminifères de L'ile de Nias: Samm. Geol. Reichs Mus., Leiden, ser. 1, vol. 8, pp. 253-278, pls. 19-21.

Glaessner, M. F., 1943, Problems of stratigraphic correlation in the Indo-Pacific region: Victoria Royal Soc. Proc., vol. 55, pp 41-80, 1 table.

Hanzawa, Shoshiro, 1930, Note on Foraminifera found in the Lepidocyclina-limestone from Pabeasan Java: Tohoku Imp. Univ. Sci. Rept., 2d ser., (Geol.), vol. 14, pp. 85-96, pls. 26-28.

1940, Micropalaeontological studies of drill cores from a deep well in Kita-Daito-Zima (North Borodino island): The Jubilee Publication in commemoration of Professor H. Yabe's 60th birthday, vol. 2, pp. 755-802, pls. 39-42. 1947, Note on Borelis pygmaeus (Hanzawa) from the Mariana Islands: Japanese Jour. Geology and Geography, vol. 20 , nos. $2-4$, pp. $9-11$, pl. 5 .
Hanzawa, Shoshiro, 1943, Notes on some Mionene Foraminifera from the Sagara oil field, Japan: Geol. Soc. Japan Jour., vol. 50, no. 595 , pp. $125-135$, pls. 7-11.

Hanzawa, Shoshiro, and Asano, Kiyoshi, 1942, Notes on some lepidocyclines from Palmalt, Tamismolon, Vera Cruz, Mexico: Japanese Jour. Geology and Geography, vol. 18, no. 4, pp. 119-126, pls. 9-12.

Hess, H. H., 1948, Major structural featues of the North Pacific -an interpretation of H. O. 5485, Rathymetric chart, Korea to New Guinea: Geol. Soc. America Bull., vol. 59, pp. 417-446.

Hoffmeister, J. E., and Ladd, H. S., 1945, Solution effects of elevated limestone terraces: Geol. Soc. A merica Bull., vol. 56, pp. 809-818.

Hydrographic Office, U. S. Navy, 1944, H. O. Chart 6060, Saipan and Tinian Islands.

Jones, T. Rupert, and Chapman, Frederick, 1900, On the Foraminifera of the orbitoidal limestones and reef rocks of Christmas Island, in Andrews, Monogrr.oh on Christmas Island, pp. 226-268, pls. 20, 21, London.

Ladd, H. S., and Hoffmeister, J. E., 1945, Geology of Lau, Fiji: Bernice P. Bishop Mus. Bull. 181, pp. 1-399, pls. 1-62, text figs. 1-41.

Nuttall, W. L. F., 1926, A revision of the orbitoids of Christmas Island (Indian Ocean): Geol. Soc. London Quart. Jour., vol. 82 , pt. 1 , pp. $22-42$, pls. 4,5 .

Piper, A. M., 1946, Water Resources of Micronesia: U. S. Commercial Company, Economic Survey of Micronesia, vol. 3, pt. 2, open file report, library, U. S. Geol. Survey; microfilm, Library of Congress.

Scheffen, W., 1932, Ostindische Lepidocyclinen: Nederlandsche Akad. Wetens. Meded., no. 21, pp. 1-76, pls. 1-14, text figs. 1-6.

Silvestri, Alfredo, 1926, Sulla Patella cassis Oppenheim: Rivista italiana paleontologia, anno. 32 , fasc. $1-\mathfrak{s}$, pp. 15-22, pl. 1 .

Tan, S. H., 1932, On the genus Cycloclypeus Carpenter: Nederlandsche Akad. Wetens. Meded., no. 19, pp. 1-194, pls. 1-24, 7 tables.

1937, On the genus Spyroclipeus H. Douvillé with a description of the Eocene Spyroclipeus vermicularis nov. sp. from Koetai in east Borneo: De Ingenieur in Nederl.Indië, Jahrg. 4, no. 10, pp. 177-193, 4 pls., 1 text fig.

Tayama, Risaburo, 1938, Topography, geography and coral reefs of Saipan: The Tropical Industry Institute, Palau, South Sea Islands, Japan, Bull. 1, pp. 1-67, pls. 1-15, 15 sketches, 3 text figs. (Japanese, unedit?d English translation in library, U. S. Geological Survey).

(no date) Geology of Saipan: U. S. Navy translation of document captured on Saipan, apparently a lecture delivered before some local scientific society. Seemingly a condensation of the preceding reference.

Umbgrove, J. H. F., 1928, Het genus Pellatispira in het indopacifische gebied; Nederlandsche Akad. Wetens. Meded., no. 10, pp. 43 (1)-102 (60), text figs. 1-10, figs. 11-80 on pls. 1931, Tertiary Foraminifera: Leidsche Geol. Meded., Deel 5, pp. 35-91.

1938, A second species of Biplanispirc from the Eocene of Borneo: Leidsche Geol. Meded., deel 10, afl. 1, pp. 82-89, figs. 1-17.

van der Vlerk, I. M., 1924, Miogypsina dehaartii nov. spec. de Larat (Moluques): Eclog. Geol. Helv., vol. 18, pp. 429432, text figs. 1-3. 
van der Vlerk, 1928a, Het genus Lepidocyclina in het indopacifische gebied; Nederlandsche Akad. Wetens. Meded., no. 8, pp. 7-86, figs. 1-58 (on 18 pls.), 3 tables.

1928b, The genus Lepidocyclina in the far east: Eclog. Geol. Helv., vol. 21, no. 1, pp. 182-211, pls. 6-23, tables A-C. 1929, Groote Foraminiferen van N. O. Borneo: Nederlandsche Akad. Wetens. Meded., no. 9, pp. 1-44, 7 pls.

Whipple, G. L., 1932, Eocene Foraminifera: Bernice P. Bishop Mus., Bull. 96, pp. 79-90, pls. 20-23.

Yabe, Hisakatsu, 1919, Notes on a Lepidocyclina-limestone from Cebú: Tohoju Imp. Univ. Sci. Rept., ser. 2 (Geol.), vol. 5 , no. 2 , pp. $37-51$, pls. $6,7$.
Yabe, Hisakatsu, and Hanzawa, Shoshire, 1925, A Lepidocycl :nalimestone from Klias peninsula, B. N. Borneo: Geol.-miinb. genootsch. Nederland en Kolonien Verh., Geol. ser., vol. 8, pp. $617-632$, pls. $1-4,4$ text figs.

1928, Tertiary foraminiferous rocks of Taiwan (Formosa): Japanese Imp. Acad. Proc., vol. 4, pp. 533-536, 3 text figs. 1929, Tertiary foraminiferous rocks of the Philippines: Tohoku Imp. Univ. Sci. Rept., 2d ser. (Geol.), vol. 11, no. 3, pp. 137 (1)-190 (54), pls. 15 (1)-27 (13).

1930, Tertiary foraminiferous rocks of Taiwan (Formosa) : Tohoku Imp. Univ. Sci. Rept., 2d ser. (Geol.), vol. 14, pp. $1-46,16$ pls. 


\section{N D EX}

[Italic numbers indicate descriptions.]

$A$

absurda, Biplanispira.

abunensis, Conomiogypsinoides

38

Acknowledgments

Acropora...

aequilateralis, Globigerinell

Amphistegina

sp.

angulosa, Lepidocyclina

Asterocyclina, sp.

38

a...

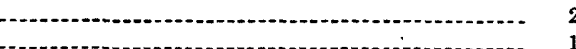
10,12, 18, 19, 20, pl. 14

bantamensis, Miogypsinoides

B

Biplanispira absurdo mirabilis...

bispherica, Orbulin

Borelis pygmaeus

$\mathrm{sp}$.

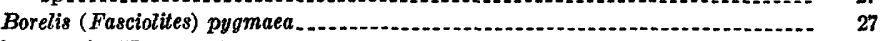

borneensis, Heterostegina.................................... 9, 10, 18, 19, 25, pls. 2,4

bridgei, Lepidocycling

Lepidocyclina (Eulepidina) .................... 10, 19, 9

brouweri, Lepidocyclina

Lepidocyclina (Nephrolepidina)

$9,10,18,19,28$, pls. $8,9,11,12$

Camerina pengaronensis saipanensis.

Candeina nitida......-

- 11

Carpenteria proteiformis plecte.

Cassidulina subglobosa

$\mathrm{sp}$.

Central divide

Cibicides cicatricosa

$$
\text { sp. }
$$

cicatricosa, Cibicides

Coast line.

conglobata, Globigerinoides.

Conomiogypsinoides abunensis

crassata, Lepidocyclina.

crassicolumnata, Pellatispira

Cycloclypeus

(17, 27

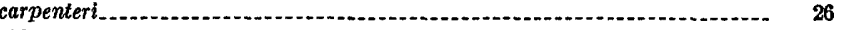

neglectus eidae

$s p \ldots$

Cycloclypeus (Cycloclypeus) carpenteri............................. 13, 19, 20, 26, pl. 14

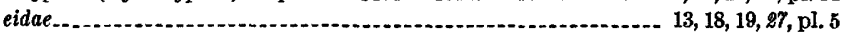

(Cycloclypeus) carpenteri, Cycloclypeus.................................... 13, 20,26, pl

eidae, Cycloclypeus....... 13,18,19,27, pl. 5

cyclostoma, Globigerinoides

cylindricum, Sporadotrema 18,28

dehaartii, Miogypsina

formosensis, Miogypsina (Miogypsinoides)

Miogypsinoides

pustulosa, Miogypsinoides.

Densinyama formation

Dentalina sp..

dilatata, Lepidocyclina (Eulepidina)

Discocyclina.

javana

sp. A. . .

sp. B.......... 8, 19, s7, pl. 12 dispansa, Orthophragmina (Discocyclina)

Donni tuff

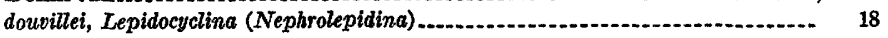

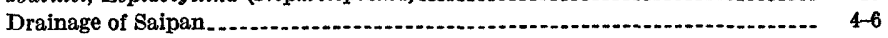

$\mathbf{E}$

eidae, Cycloclypeus

Cycloclypeus (Cycloclypeus) .

Cycloclypeus neglectus..................................................... 27

elphidroides, Rotalia

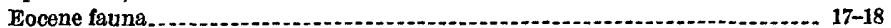

Eodictyoconus

Eponides umbonatus.

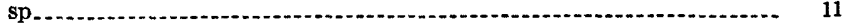

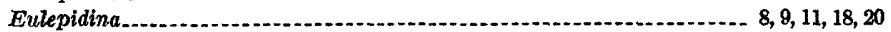

formosa $\ldots$

gibbosa

richthofeni -

sp. A. A

sp. B

(Eulepidina) bridgei, Lepidocyclina ..................................... 10, 17, 84

dilatata, Lepidocyclina.

formosa, Lepidocyclina......... 10, 18, $\$ 4$ pIs. 7, 10

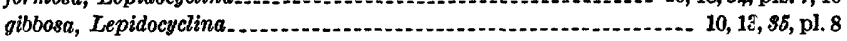

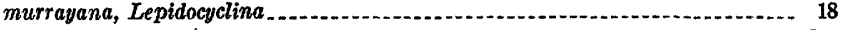

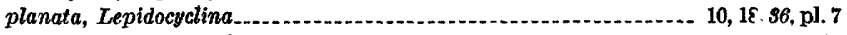

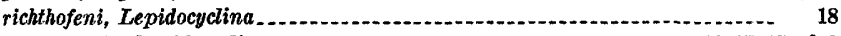

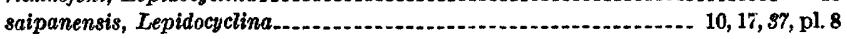

F

Fabiania

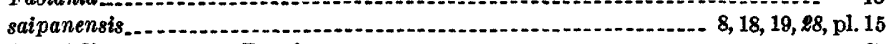

(Fasciolites) pygmaea, Borelis. .

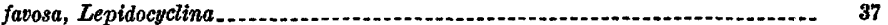

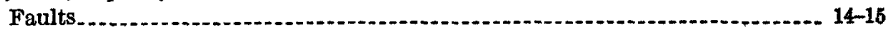

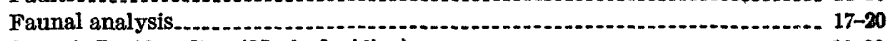

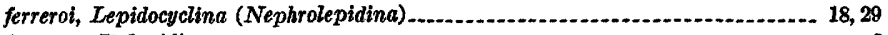

formosa, Eulepidina

Lepidocyclina $\ldots$

Lepidocyclina (Eulepidina)

formosensis, Miogypsinoides................... 9, 10, 12, 13,18,19, 20, 25, 38, pls 8,13,14

Miogypsina (Miogypsinoides) dehaartii...................................... 38, 39

Geology

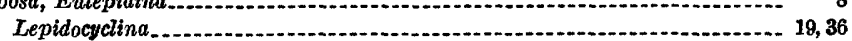

Lepidocyclina (Eulepidina)

Globigerina kochi

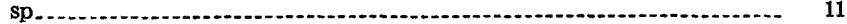

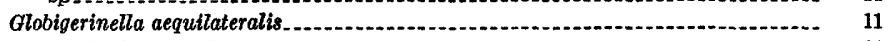

Globigerinoides conglobata

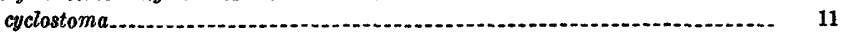

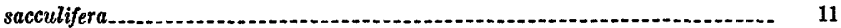

sp.

Globorotalia menardii
tumida

H

Halimeda

tuvathaensis.

13

Heterostegina_. borneensis. ............ 9, 10, 18, 19, 28 pls. 2,4

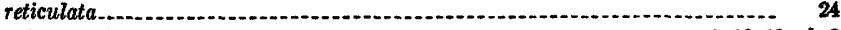

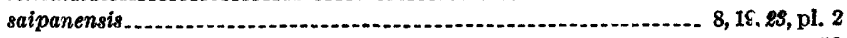

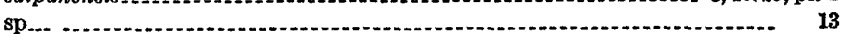


higginsi, Spiroclypeus.

Page

howchini, Austrotrillina

Trillina

$10,19,24$, pls. 4,5, $10,12,18,19,20$, pl. 14

\section{I}

inflata, Mfiogypsina Mfiogypsina (Miogypsina) Introduction.

systematic section

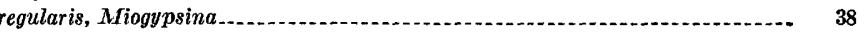

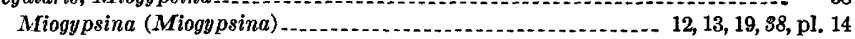

isolepidinoides, Lepidocyclina (Nephrolepidina) _.............................. 30, 31

javana, Discocyclina.

J

$\mathbf{K}$

Katacyclocly peus

kochi, Globigerina

L

Lakes and swamps

Laulau limestone

Lepidocyclina.

angulosa

bridgei.

brouweri.

crassata.

favosa

formosa.

gibbosa

murrayana

newtoni.

parva

perornata

planata.

saipanensis.

sumatrensis.

undosa

verbeeki.

yurnagunensis

yurnagunensis morganopsis

Lepidocyclina (Eulepidina) bridgei.

dilatata.

formosa.

gibbosa

murrayana

planata.

richthofeni.

saipanensis.

... 10, 17,19, 97 , pl. 8 9, 10, 18,10,28, 29, pls. $8,9,11,12$ douvillei

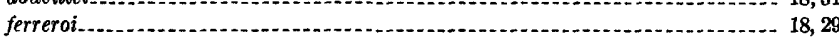

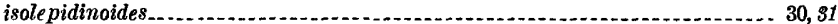

mariae

melanesiana

29
18,30

newtoni

nipponica..............

parva

sondaica

sumatrensis

verbeeki.

$9,10,19,32$, pls. 10,11

Lepidocyclina) sumatremsis, Orbitomdes.

verbeeki, Orbitoides.

Linestone units

Limestones of uncertain age

Literature cited.

Location of Saipan

ucernula, Pyrgo $12,18,19,20,33,34,39$, pls. 11,12

(1)

1

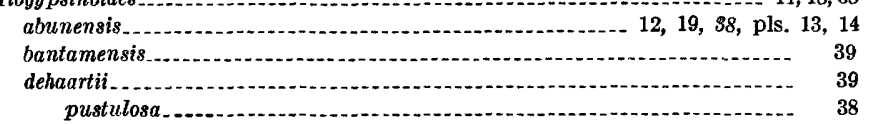

formosensis ................... $9,10,12,13,18,19,20,25,38,39$, pls. $8,13,14$

(Miogypsinoides) dehaartii formosensis, Miogypsina

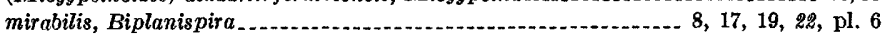

Heteros pira...

morganopsis, Lepidocyclina yurnaguneneis

murrayana, Lepidocyclina.

Lepidocyclina (Eulepidina)

$\mathbf{N}$

Naftan limestone.

$12,19,37$, pl. 13

$2,13,19,38$, pl. 14

38, 39

$12,19,37$, pl. 13

$12,13,19,38$, pl. 14

$12,13,19,38$, pl. 13

neglectus eidae, Cycloclypeus

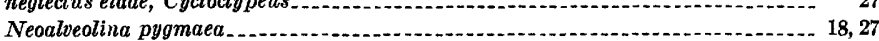

Nephrolepidina.

sp. (?)...

(Nephrole pidina) brouweri, Lepidocyclina

douvillei, Lepidocyclina

ferreroi, Lepidocyclina.

mariae, Lepidocyclina

melanesiana, Lepidocyclina . . . .

newtoni, Lepidocyclina.......... 9, 29, pls. 12, 14

nipponica, Lepidocyclina _........................................... 33, 34

parva, Lepidocyclina

pandaica, 1

sumatrensis, Lepidocyclina

verbeeki, Lepidocyclina.

newtoni, Lepidocyclina.

Lepidocyclina (Nephrolepidina) .......... 9, 19, 29, pls. 12, 14 nipponica, Lepidocyclina (Nephrolepidina) nitida, Candeina.

o

Operculina.

ictoriensis

sp $\ldots . . . . . . . . .10,13,17,19$, 21 , pl. 4

Orbitoides sumatrensis

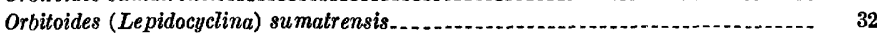

verbeeki.

orbitoideus, Spiroclypeus.............. 9, 19, 26, 29, pl.

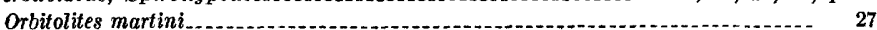

Orbitites martini.

Orbulina bispherica

universa.$$
\text { sp. }
$$

Orthophragmina (Discocyclina) dispansa

\section{$\mathbf{P}$}

parva, Lepidocyclina

Lepidocyclina (Nephrolepidina)

Pellatispira crassicolumnata. reticularis.

rutteni.

pengaronensis, Camerina

mamillata, Miogypsina

38

arginalis, Sorites

mariae, Lepidocyclina (Nephrolepidina)

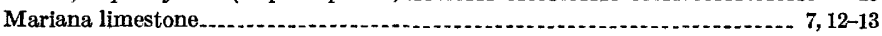

martini, Orbitolites.

Sorites
tansa limestone........................

melanesiana, Lepidocyclina (Nephrolepidina) pengaronensis, Camerina

planata, Lepidocyclina.

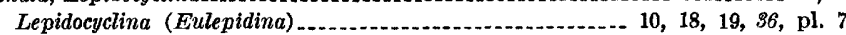

plecte, Carpenteria proteiformis ............................................. 28

Victoriella .......... 10, 18, 19, 28, pl. 14

Pliocene-Pleistocene fauna

pleurocentralis, Spiroclypeus

\section{0} 39 18

.


proteiformis plecte, Carpenteria.

pustulosa, Miogypsinoides dehaartii

pygmaea, Borelis (Fasciolites)

Neoalveolina.

Page

28

$9,10,18,19,20,25,27$, pls. 12,13

murrhina

$\mathrm{sp}$

11

Recent deposits.

reticulata, Heterostegina.

richthofeni, Eulepidina

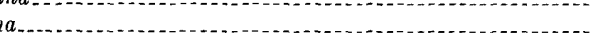

Lepidocyclina (Eulepidina)

Rotalia elphidroides.

rutteni, Pellatispira.

$8,18,19,22$, pl. 6

s

sacculifera, Globigerinoides

saipanensis, Camerina

Fabiania

Heterostegina

Lepidocyclina

Lexidocyclina (Eulepidina)

Streblus

Streblus

20 , pl.

$8,18,19,28$, pl. 1

$8,19,28$, pl. 2

eminulina, Sphaeroidinella

$10,17,19,3 \%, \mathrm{pl}, 8$

$10,17,19,27, \mathrm{pl} .5$

sondaica, Lepidocyclina (Nephrolepidina)

Sorites marginalis.

martini.

$12,19,2 \%$, pls. 12,14

Sphaeroidina sp.

Sphaeroidinella seminulina

Spiroclypeus

higginsi...

orbitoideus...

pleurocentralis

tidoenganensis.

vermicularis

sp...

Sporadotrema cylindricum
Springs

Page

Stratigraphy......... 7-15, 17

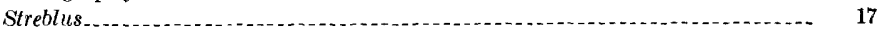

saipanensis_.....

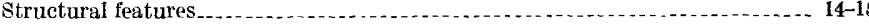

subglobosa, Cassidulina

sumatrensis, Lepidocyclina Lepidocyclina (Nephrolepidina)

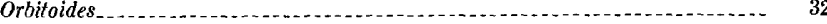

Orbitoides (Lepidocyclina)

\section{$\mathrm{T}$}

Tagpochau limestone $7,11-12$

Terrace platform

tidoenganensis, Spirocly peus..................... 9, 10,18, 19, 25, pls. 3, 4, 7

Topography of Saipan........ $3-4$

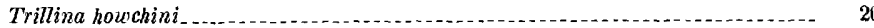

tumida, Globorotalia

turathaensis, Haliotis

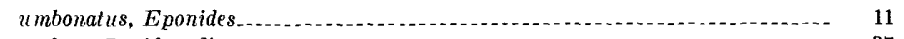

undosa, Lepidocyclina

universa, Orbulina

\section{$\mathrm{V}$}

verbeeki, Lepidocyclina. Orbitoides (Lepidocyclina)

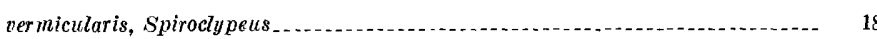

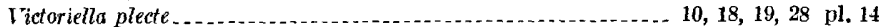

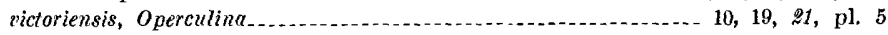

Volcanic rocks................... 7

yurnagunensis, Lepidocyclina

yurnagunensis morganopsis, Lepidocyclina 


\section{PLATES 2-15}


Figures 1-3, 5. Heterostegina borneensis van der Vlerk (p. 23).

\section{PLATE 2}

1, 5 . Transverse sections, $\times 40$, station

4, 6. Heterostegina saipanensis Cole, $\mathrm{n}$. sp. (p. 23)

4. Median section, $\times 16$, station S-24; holotype U.S.N.M. 560272

4. Median section, $\times 16$, station $S-24$; holotype U.S.N.M.

7-19. Camerina saipanensis Cole, $\mathrm{n}$. sp. (p. 20).

7. Transverse section of small individual, $\times 16$, station $\mathrm{S}-24$.

Transverse section of small individual, $\times 16$, station $\mathrm{S}-2$

. External view of small individual, $\times 10$, station $8-24$.

$10-13$. Transverse sections of large individuals, $\times 16$, station $S-24$

14-17. Median sections of large individuals. $X 16$, station $\mathrm{S}-24$.

18, 19. External views of large individnals, $X$ 10, station $8-24 ; 18$, nolotype U.S.N.M. 560271a. 


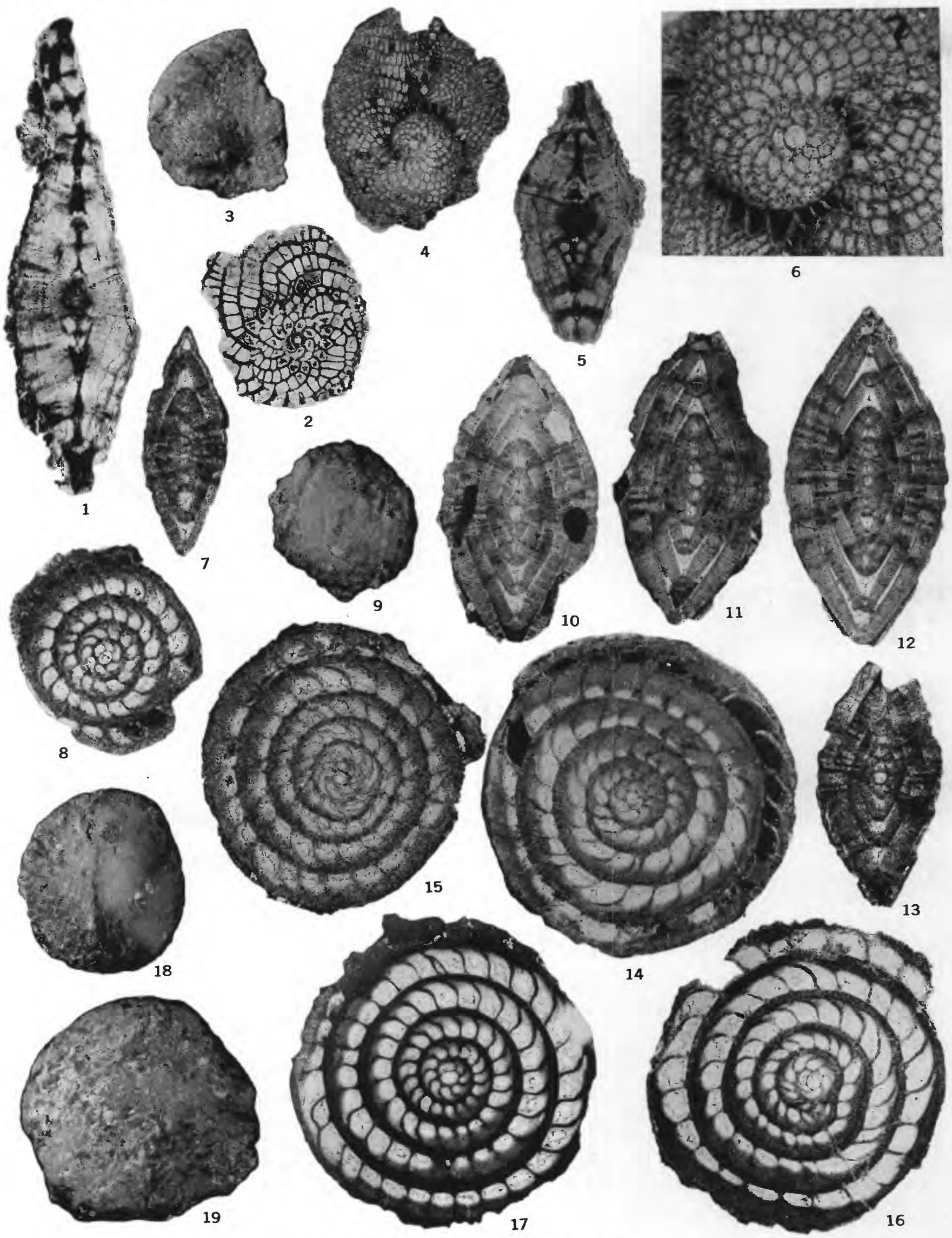

HETEROSTEGINA AND CAMERINA 


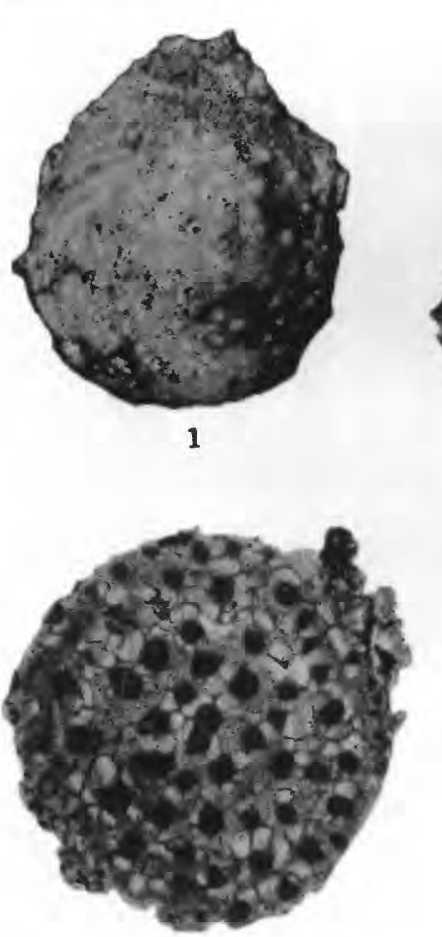

4
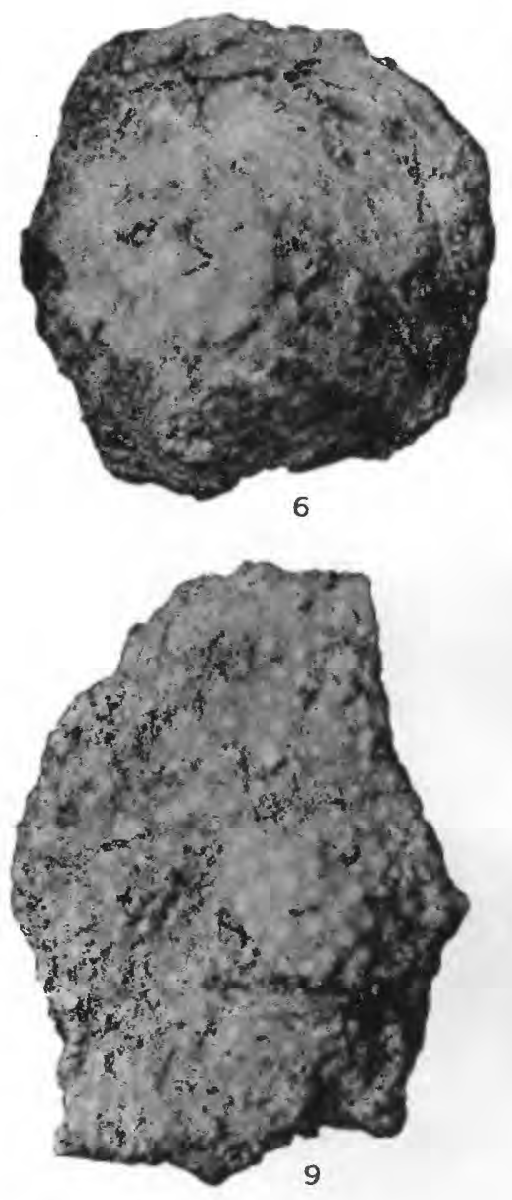
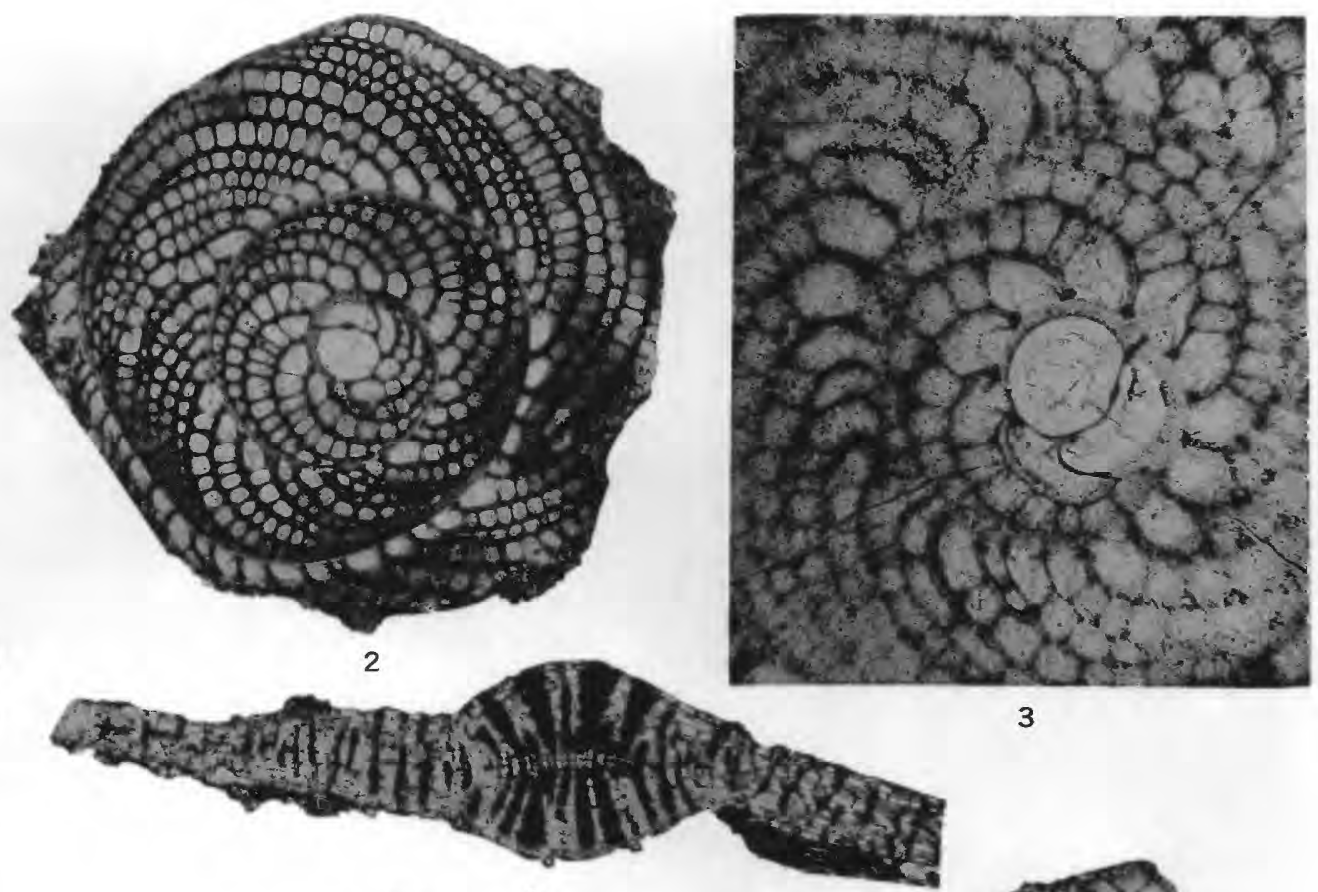

3

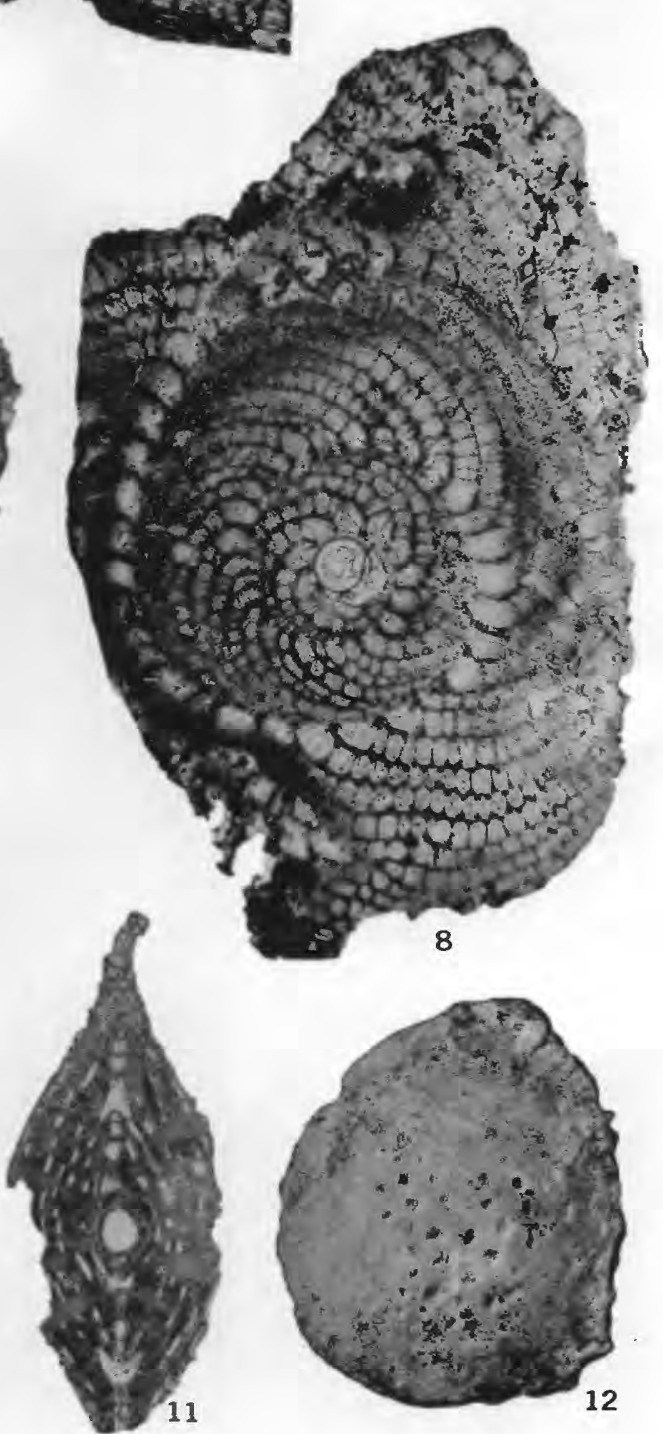

SPIROCLYPEUS 
PLATE 3

FIGURES 1-12. Spiroclypeus tidoenganensis van der Vlerk (p. 25)

1. External view of megalospheric individual, $\times 10$, to illustrate pustulate central area and narrow rim, station S-30.

2. Median section of a megalospheric individual, $\times 16$, with three chamberlets in the first subdivided chamber, station S-30.

3. Central part of the specimen illustrated in figure $8, \times 40$, showing the first subdivided chamber with seven chamberlets, station S-30.

. Section parallel to the median section, $\times 16$, but through the zone of lateral chambers showing the pillars and the shape of the lateral chambers, station S-30.

5. Transverse section of a microspheric individual, $\times 10$, station $\mathrm{S}-30$

6. External view of a megalospheric individual, $\times 10$, with slight development of a rim, station S-30.

7. Median section of a microspheric individual, $\times 10$, station $\mathrm{S}-30$.

9. External view of a microspheric specimen, $x 10$, with a small eceentric umbo and wide flange. The entire surface pustulate, with the greatest concentration of pustuies on the umbo, station $\mathrm{S}-30$.

10. External view of a megalospheric specimen, $\times 10$, with a wide rim, station $\$$ - 30

12. External view of a megalospheric specimen, $\times 10$, showing the pits developed by the more rapid weathering of the pustules and pillars, station $\mathrm{S}-30$. 


\section{PLATE 4}

FigURES 1-3, 13, 14, 19. Spiroclypeus higginsi Cole (p. 24)

2. Embryonic chambers and initial equatorial chambers of the specimen in figure 3 of this plate, $\times 40$, station S-34c.

. Slightly oblique median section, $\times 16$, station S-34c.

13. Transverse section, $\times 40$, approximately centered, station

14. Oblique median section, $\times 40$, showing the embryonic and equatorial chambers, station $\mathrm{S}-34 \mathrm{~b}$.

4. 5. 10.

Spiroclypeus orbitoideus $\mathrm{H}$. Douville (p. 26).
4. Transverse section, $\times 16$, showing the heavy umbonal pillar, station S-16.

4. Transverse section, $\times 16$, showing the heavy umbonal pillar, station $\mathrm{S}-16$.
5 . Transverse section, $\times 16$, showing the thin walled lateral chambers arranged in regular tiers, station $\mathrm{S}-3$.

6-12. Spiroclypeus tidoenganensis van der Vlerk (p. 25).
6 . Transverse section, $\times 16$, near center of the test, station S-3.

Oblique transverse section, $\times 16$, station $S-3$.

8 . Transverse section, $\times 16$, near the periphery of the test, station $\mathrm{S}-3$.

9. Transverse section, $\times 16$, showing the thin flange and the thick floors and roofs of the lateral chambers, station S-3.

11. Transverse section, $\times 16$, station $\mathrm{S}-3$.

12. Oblique median section, $\times 12$, station $S-3$.

15. Operculina sp. (p. 21).

16-18. Median section nearly centered, $\times 40$, station S-30.

16. Oblique transverse section near the center, $\times 16$, station $\mathrm{S}-13$.

17. Transverse section not at the center, $\times 16$, station $S-13$.

18. Oblique median section, $\times 40$, showing the embryonic and equatorial chambers, station $S-25$. 


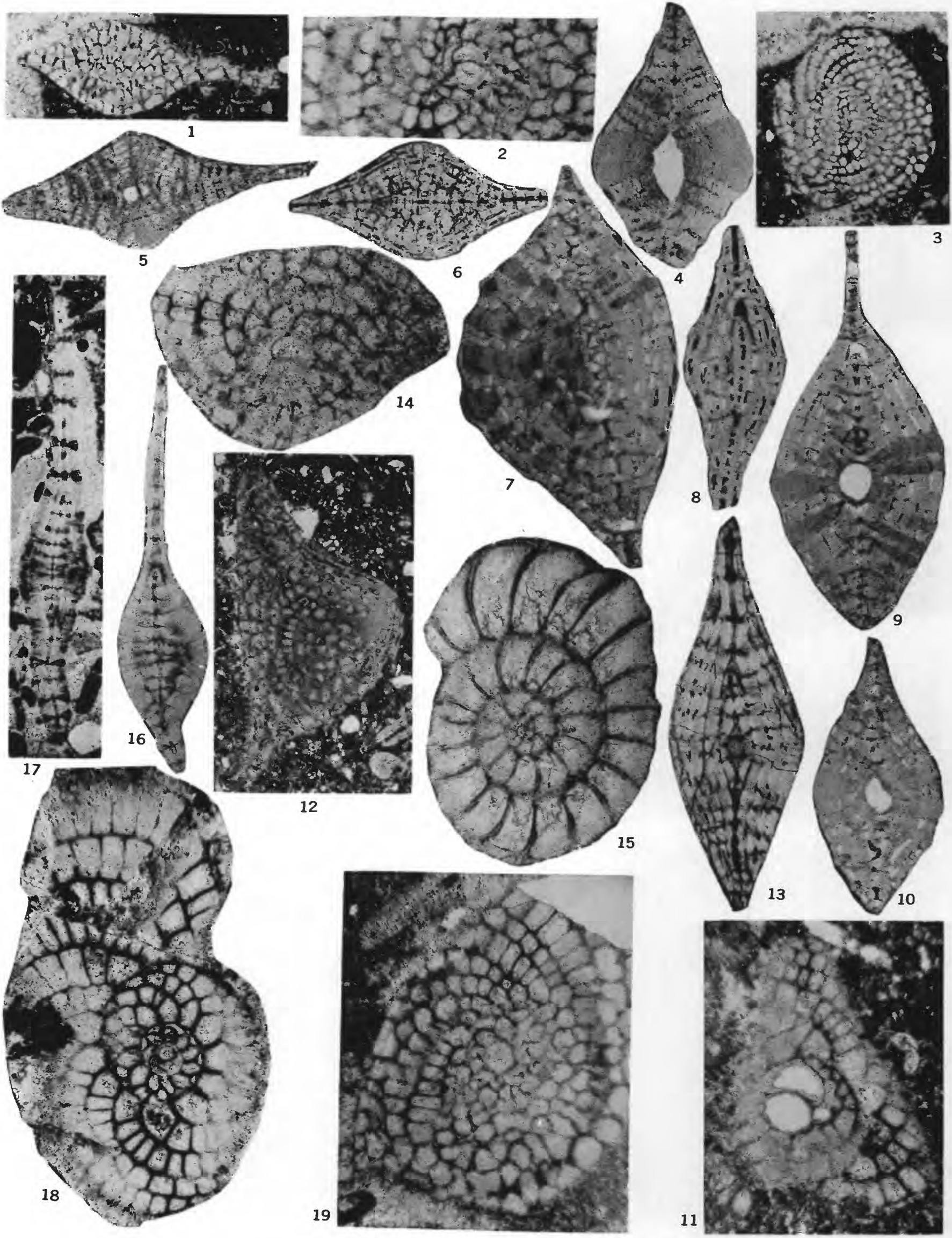




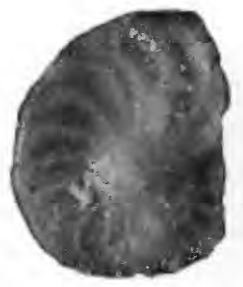

1
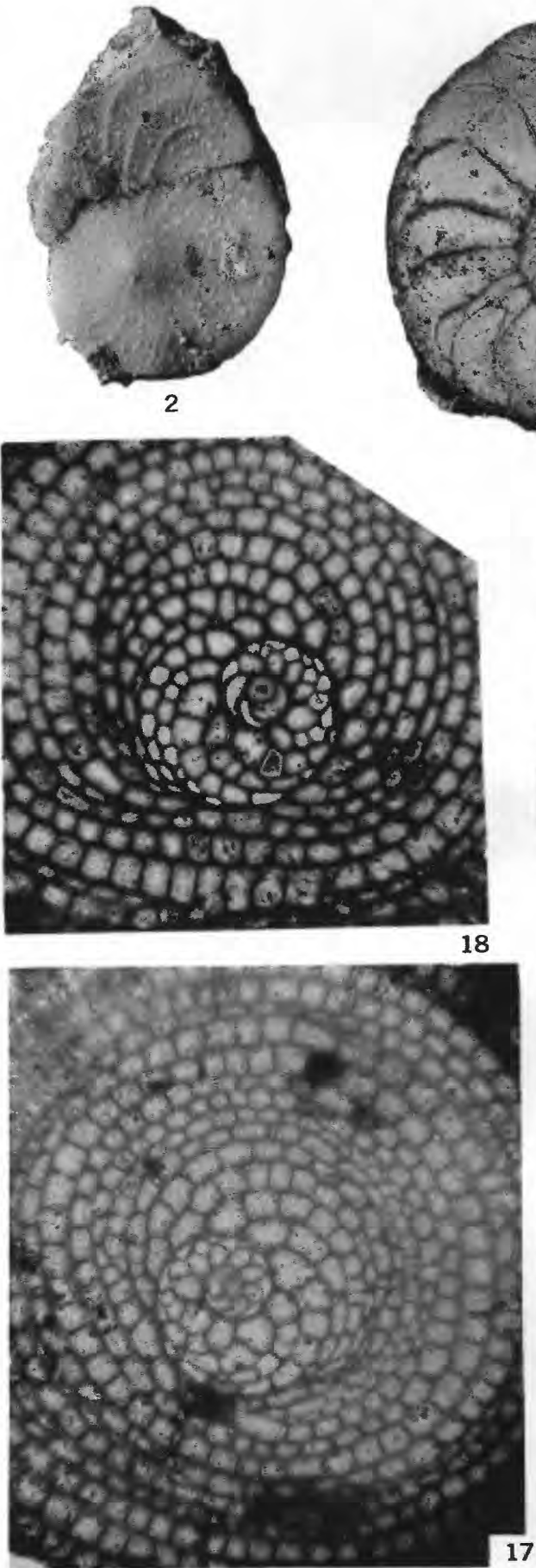
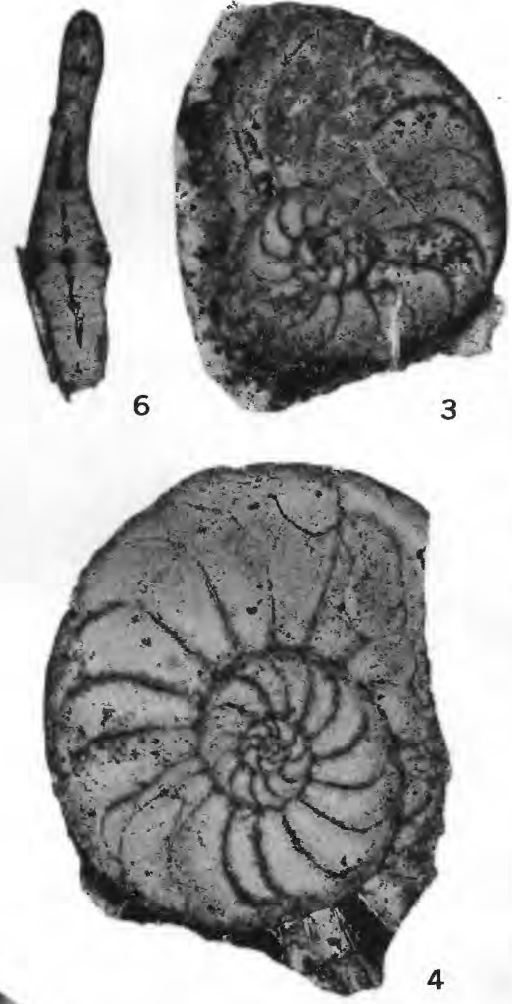

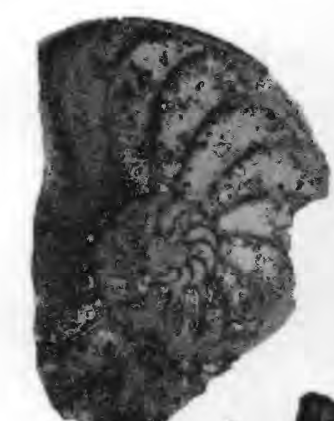

5

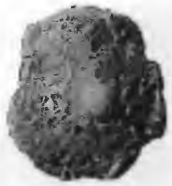

12

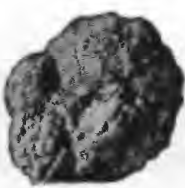

$8 \mathrm{~b}$
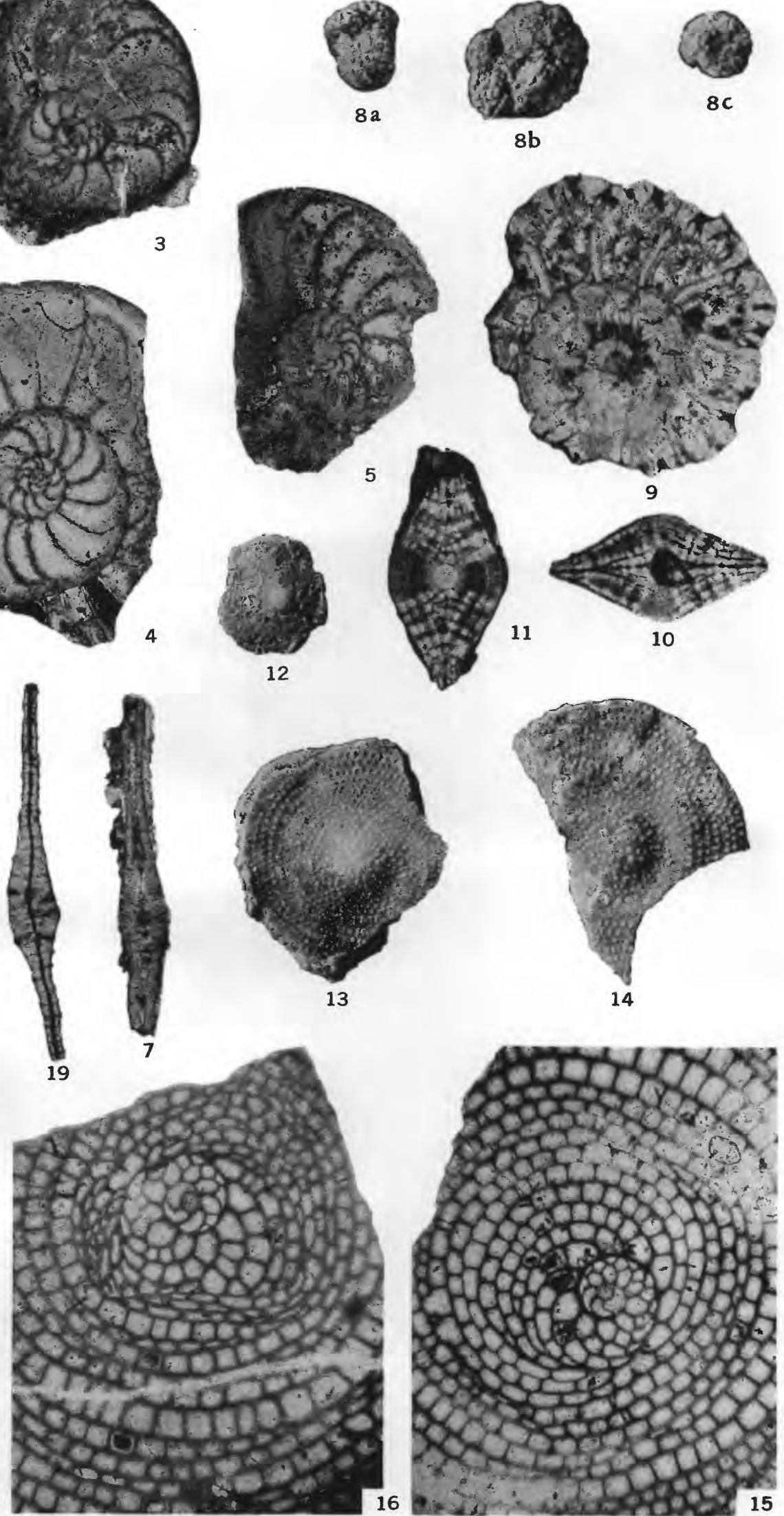

OPERCULINA, STREBLUS, SPIROCLYPEUS, AND CYCLOCLYPEUS 


\section{PLATE 5}

Figures 1-7. Operculina victoriensis Chapman and Parr (p. 21).

1. External view, $X 10$, of a slightly ornamented individual, station S-34a.

2. External view, $\times 10$, of a highly ornamented individual, station $S-34 a_{\text {. }}$

$3-5$. Median sections, $\times 16$, station $S-34 a$.

8, 9. Streblus saipanensis Cole, n. sp. (p. 27)

8i-c. External views of three specimens, $\times 15$, showing apertural, ventral, and dorsal views, station S-34a; specimen b is the holotype U.S.N.M. 560273 .

9. Median section, $\times 40$, station S-34a.

10-12. Spiroclypeus higginsi Cole (p. 24).

0, 11. Transverse sections, $X$ i6, station $S-34 a$

3-19. 12. External

13-19. Cycloclypeus (Cycloclypeus) eidae Tan. (p. 27).

13, 18. External views, $\times 10$, station $S-34 a$.

15 . Vertical section, $\times 16$, station $S-34 a$, 


\section{PLATE 6}

Fi@unes 1-8. Pellatispira rutteni Umbgrove (p. 22).

$1-4$. Vertical sections, $\times 16$, station $\mathrm{S}-24$.
5, 6. External views, $\times 10$, station $\mathrm{S}-24$.

9-19. Biplanispira mirabilis U, Ubgrove (p. 22)

9-14. Vertical sections, $\times 16$, station S-24.

15-17. Median sections, $\times 16$, station S-24.

that possess depressed central areas, $\times 10$, station S-24

19. External views of small, lenticular specimens with well-developed pustules, $\times 10$, station $S-24$ 


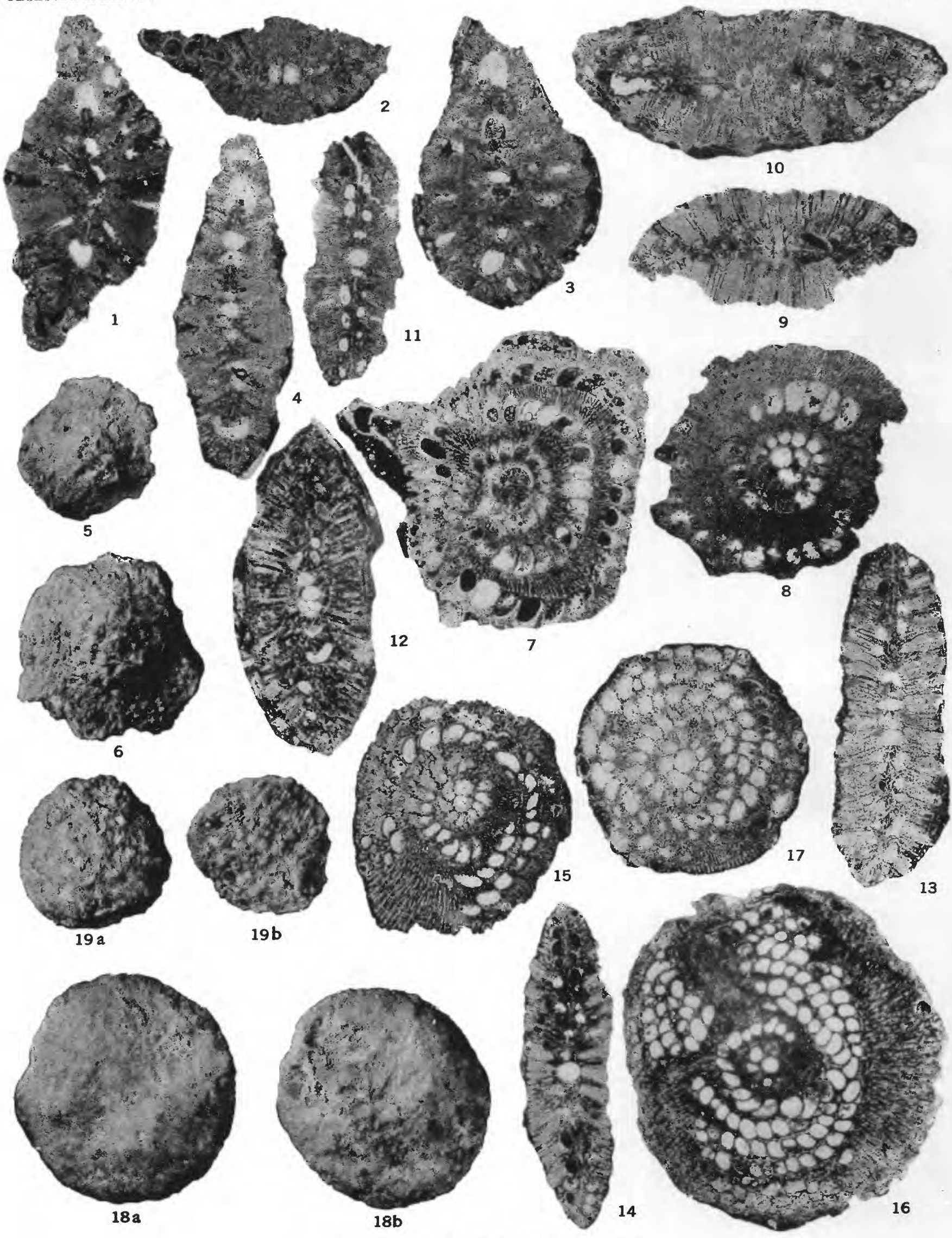

PELLATISPIRA AND BIPLANISPIRA 

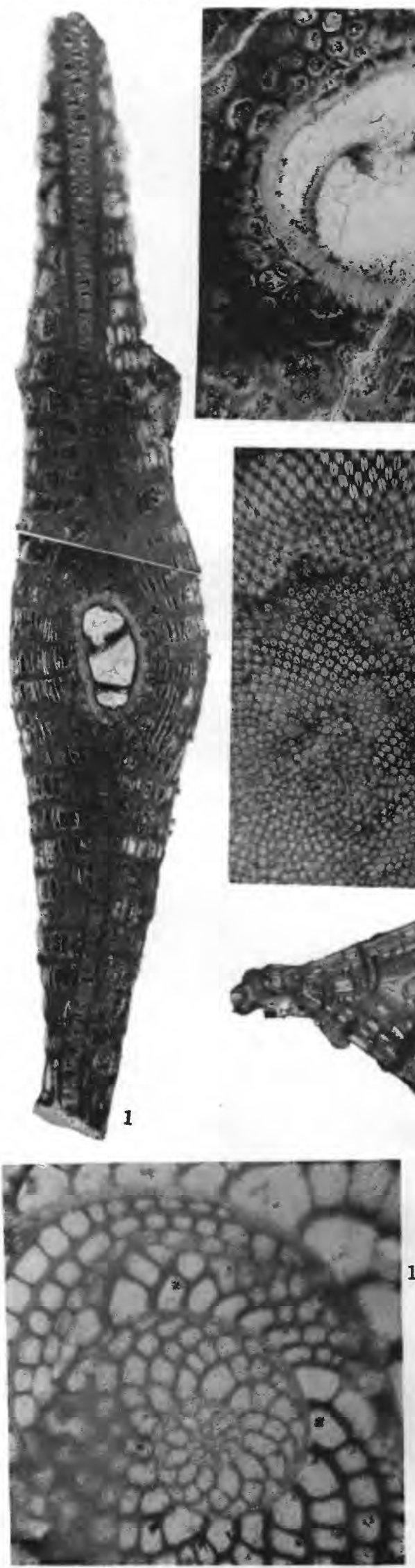
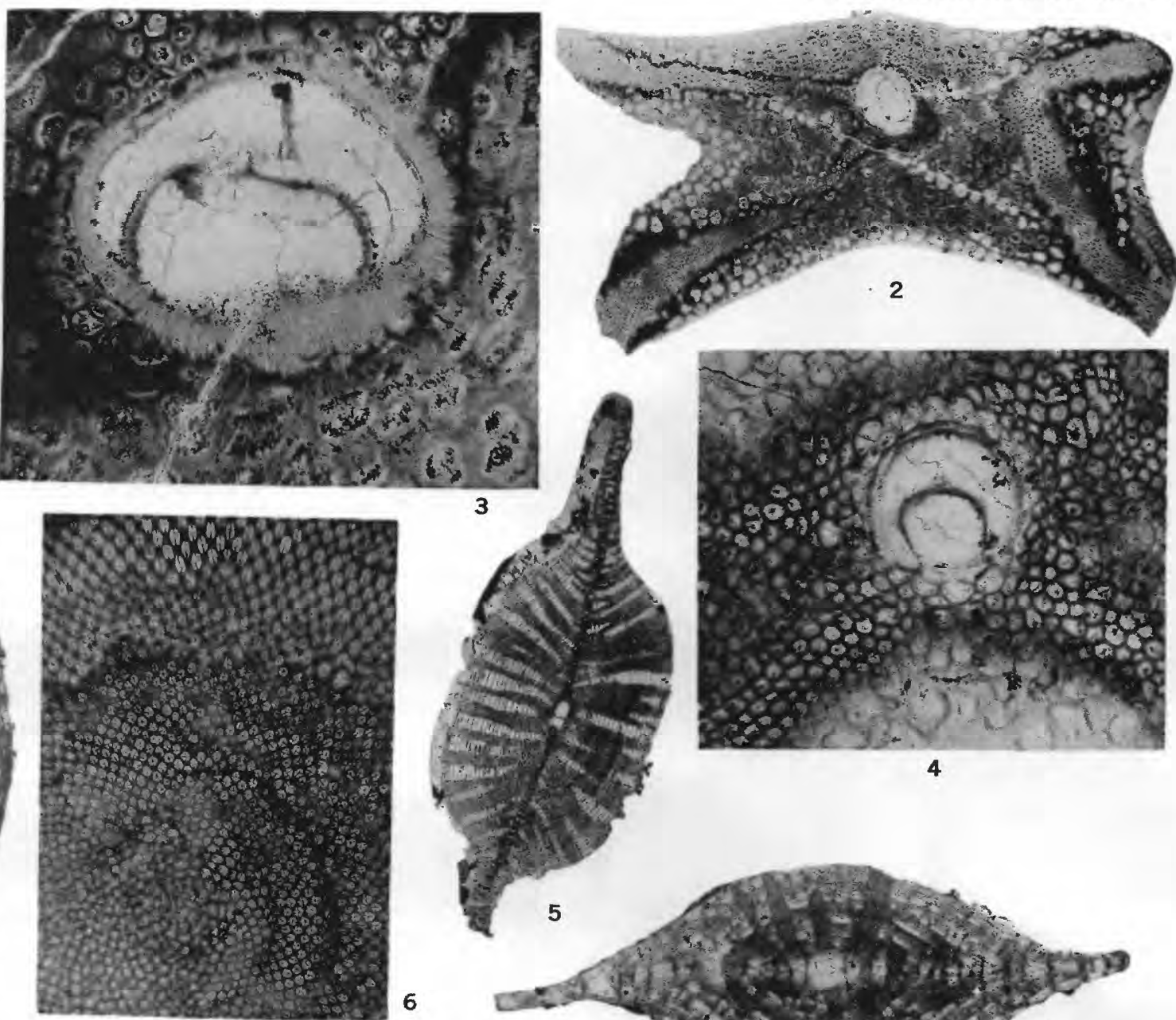

4
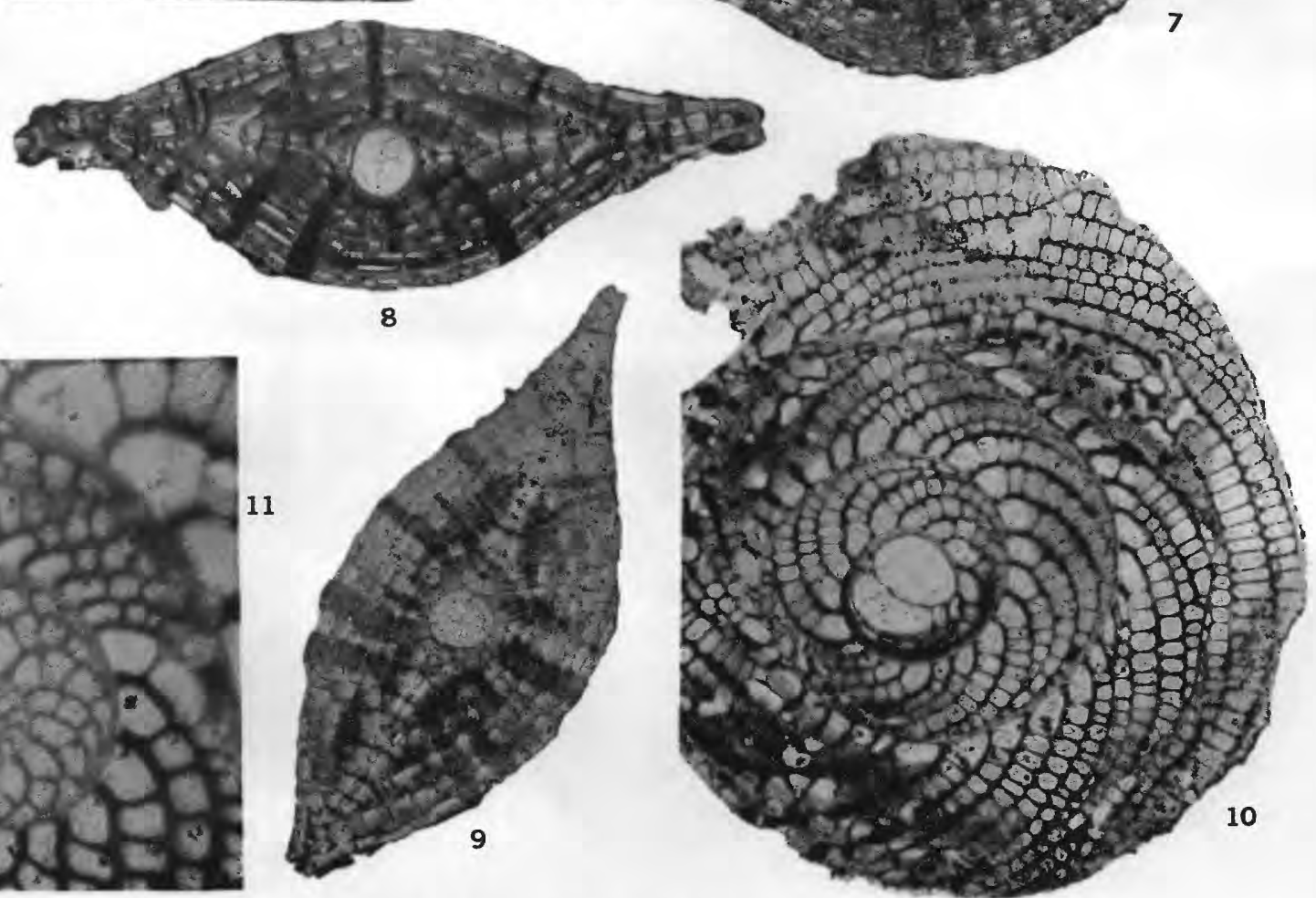

LEPIDOCYCLINA AND SPIROCLYPEUS 


\section{PLATE 7}

FinURES 1-3. Lepidocyclina (Eulepidina) planata Oppenoorth (p. 36).

1. Vertical section, $X 7$, station $\mathrm{S}-25$.

2. Equatorial section, $\times 7$, station S-25.

4, 5. Lepidocyclina (Eulepidina) formosa Schlumberger $(0,31)$.

4. Embryonic chambers, some equatorial chambers, and some lateral chambers, of a megalospheric individual, viewed in plan, $X 40$, station $\mathrm{S}-25$.

5. Vertical section, $\times 7$, Stearns station Sn-39.

6. Lepidocyclina (Nephrolepidina) parva Oppenoorth (p. 30)

6. Lepidocyclina (Nephrolepidina) parva Oppenoorth (p. 30).

7-11. Spiroclypeus tidoenganensis van der Vlerk (p. 25)

7-9. Transverse sections, $\times 16$, of megalospheric individuals, station $\mathrm{S}-30$.

10. Median section, $\times 16$, of a megalospheric individual, station $\mathrm{S}-30$

11. Initial part of the microspheric individual illustrated on plate 3 , figure $7, \times 40$, station $5-30$. 


\section{PLATE 8}

Figcre 1. Lepidocyclina (Nephrolepidina) brouweri L. Rutten (p. 28).

2-7. Lepidocyclina (Eulepidina) gibbosa Yabe (p. 35).

2 , 3. Vertical sections, $\times 16$, station $\mathrm{S}-34 \mathrm{a}$.

4. External view, $\times 10$, station $\mathrm{S}-34 \mathrm{a}$.

6. Equatoria! sections, $\times 16$, station $\mathrm{S}-34 \mathrm{a}$

7. Vertical section, $\times 16$, of a microspherie individual, station S-34a.

8-15. Lepidocyclina (Eulepidina) saipanensis Cole, n. sp. (p. 37).

9. Equatorial sections, $\times 16$, station S-34a.

0-13. Vertical sections, $\times 16$, showing range of size of individuals, station S-34a.

16, 17. Spiroclypeus higginsi Cole (p. 24).

16. Transverse section, $X 16$, station S-34a.

18, 19. Miogypsinoides formosensis Yabe and Hanzawa (p. 38).

18. Vertical section, $\times 40$, of a specimen that was ground first to the equatorial layer on one side, station S-34a. 19. Equatorial section, $\times 16$, station $S-34 a$. 

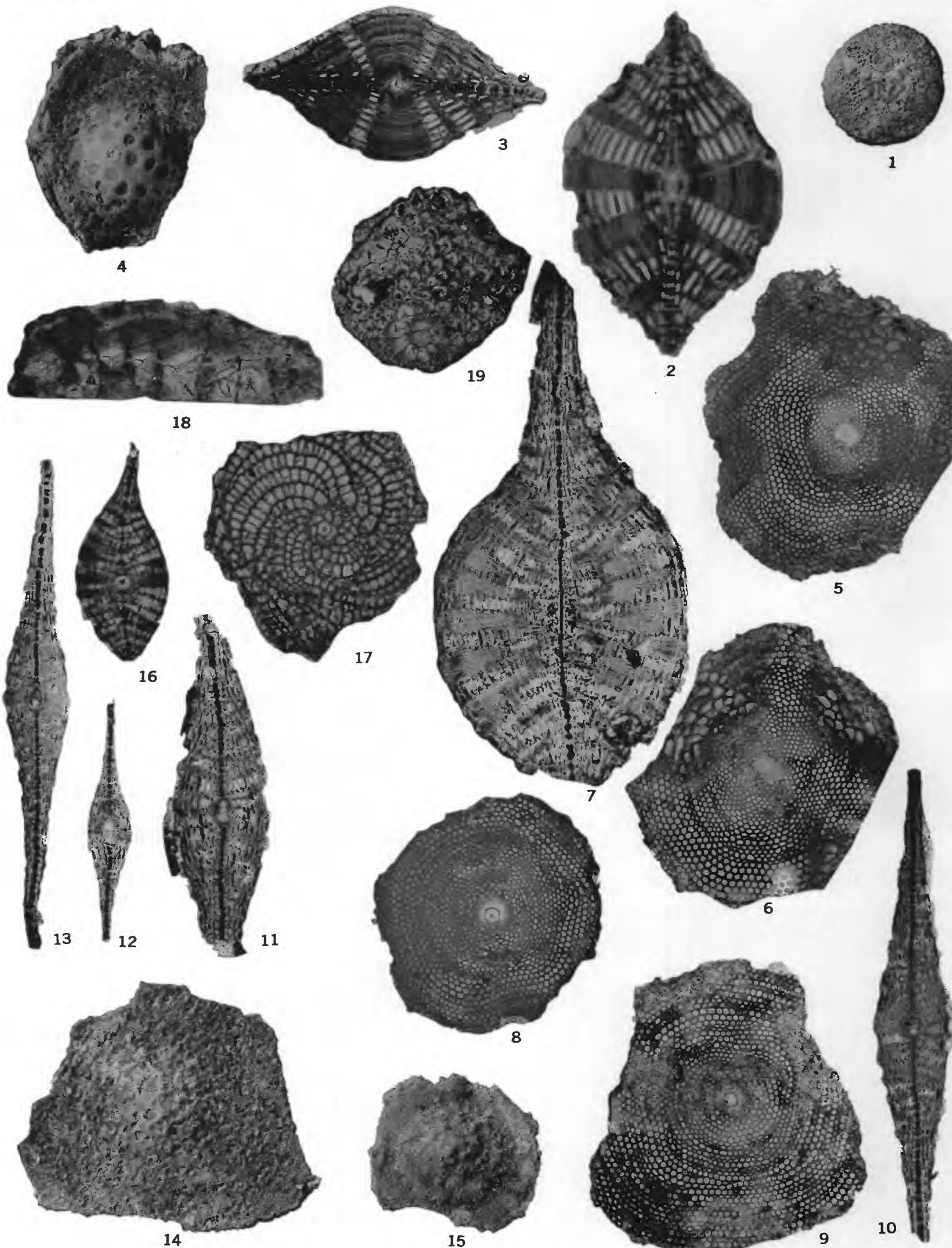

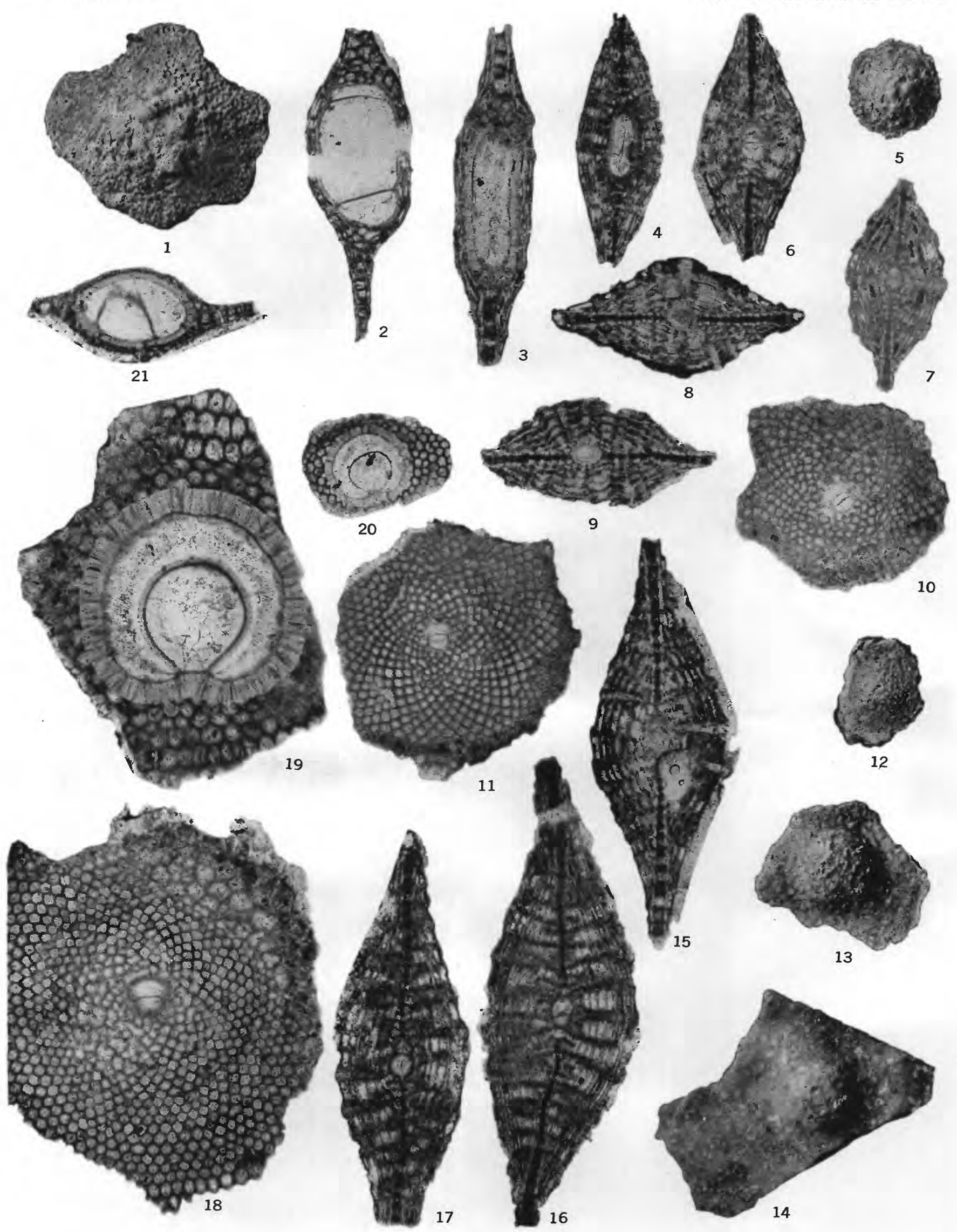

LEPIDOCYCLINA

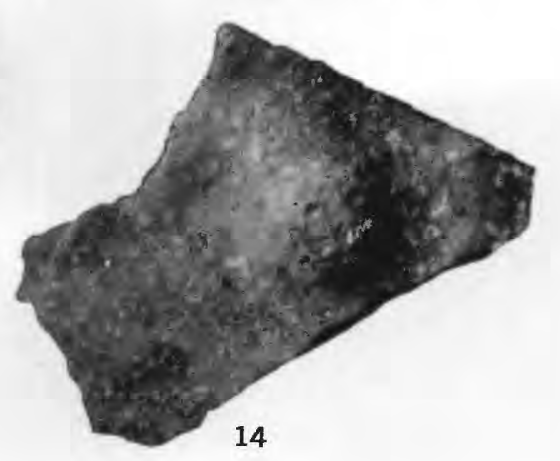




\section{PLATE 9}

FIGURE 1. Lepidocyclina (Nephrolepidina) brouweri L. Rutten (p. 28). 2-4, 13, 14, 19-21. Lepidocyclina (Eulepidina) bridgei Cole 1 .

$2-4,21$. Vertical sections showing variation in size of the embryonic chambers and in the number of lateral chambers; $2,4,21, \times 16 ; 3 \times 40$, station $5-34 a$.

13. External view of the holotype, $\times 10$, station S-34a. U.S.N.M. 560274a.

14. External view of a specimen with a smaller inflated umbo, $\times 10$, station $S-34$.

19. Equatorial section showing the thick outer wall of the embryonic apparatus, $\dot{X} 40$, station $S-34 a$

20. Equatorial section, $\times 16$, station $S-34 a$.

5-12, 15-18. Lepidocyclina (Nephrolepidina) parva Oppenoorth (p. 30).

5. External view, $\times 15$, station $\mathrm{S}-34 \mathrm{a}$.

$6-9,15-17$. Vertical sections, $\times 40$, station $\mathrm{S}-34 \mathrm{a}$.

12. External view, $\times 10$, station $\mathrm{S}-34 \mathrm{a}$. 
PLATE 10

FicURES 1-6. Lepidocyclina (Eulepidina) formosa Schlumberger (p. 34)

1. Vertical section of a microshperic individual, $\times 7.2$, Station $\mathrm{S}-25$.

2. Part of equatorial section of same specimen, $\times 16$, showing equatorial chambers.

3. External view, $\times 2$, station $\mathrm{S}-25$.

4. Vertical section of a megalospheric individual, $\times 10$, station $\mathrm{S}-25$.

5. Vertical section of a megalospheric individual, $\times 8$, Stearns station sn-39.

6. Horizontal section of a megalospheric individual, $\times 8$, Stearns station $\mathrm{Sn}-39$.

7-10. Lepidocyclina (Nephrolepidir

7 External view, $\times 10$, showing putulate, inflated centrai portion surrounded by a narrow, thin rim, station S-30.

8. Oblique horizontal section, $\times 21$, station $S-30$.

9. Enlargement, $\times 40$, of embryonic apparatus of specimen shown in figure 8 , station $5-30$

10. Vertical section, $X 21$, station $S-30$.

11-18. Lepidocyclina (Nephrolepidina) paroa Oppenoorth (p. 30)

11, 12. Horizontal sections of megalospheric individuals, $\times 40$, station $\mathrm{S}-25$

13, 14. Vertical sections of megalospheric individuals, $\times 40$, station $\mathrm{S}-25$.

15, 16. Vertical sections of microspheric mdividuals, $\times 16$, station S-25.

17. Horizontal section of a microspheric individual, $X 16$, station $S-25$. 


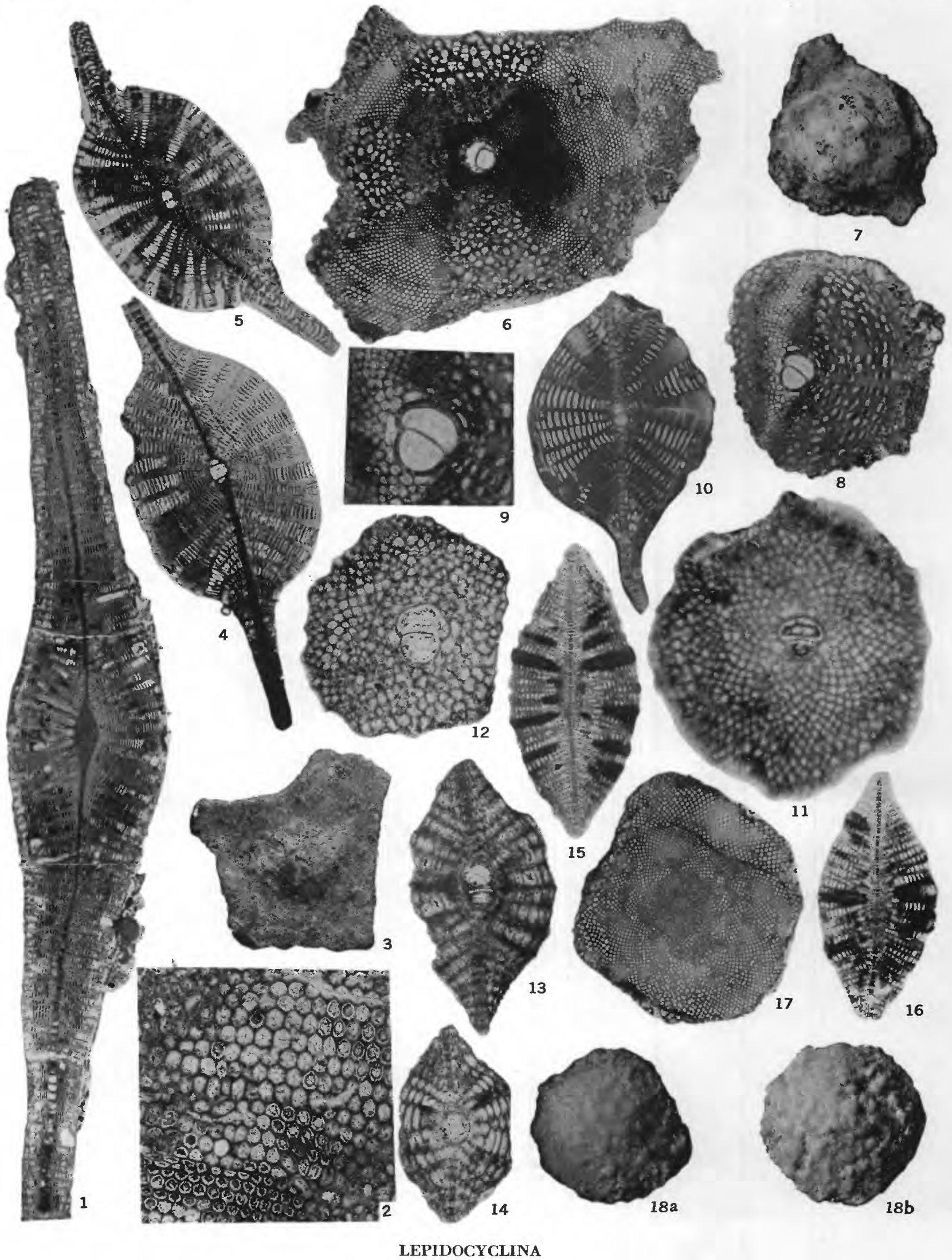



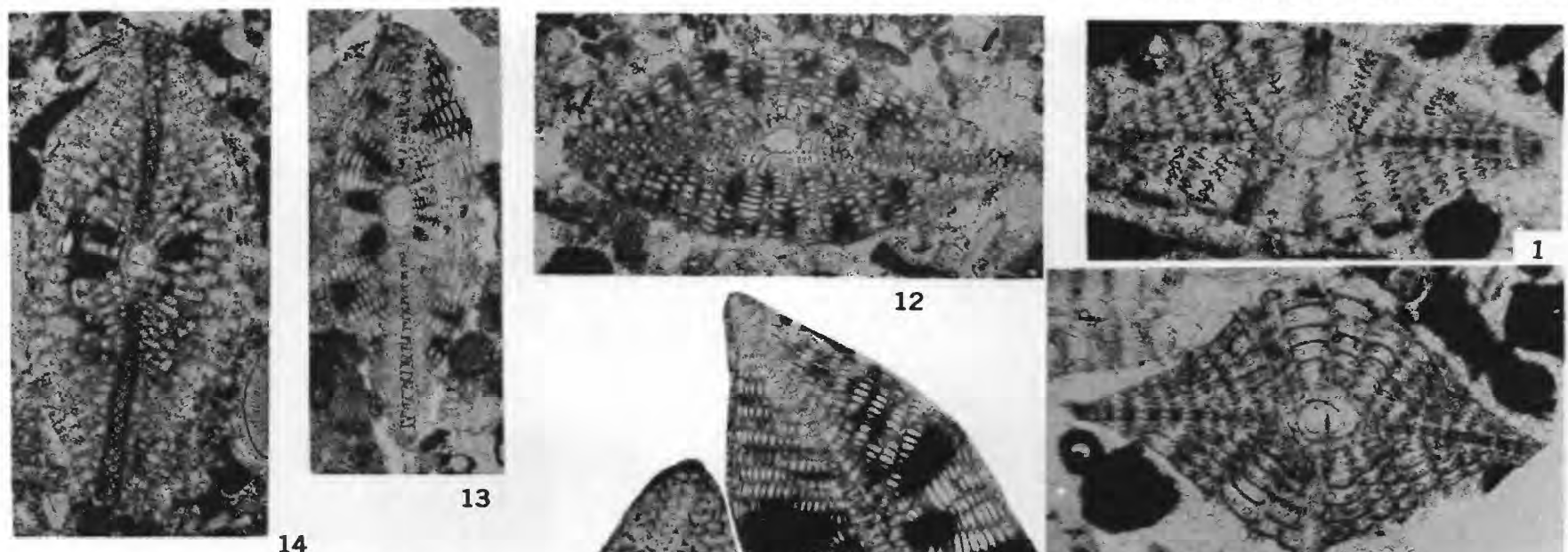

14
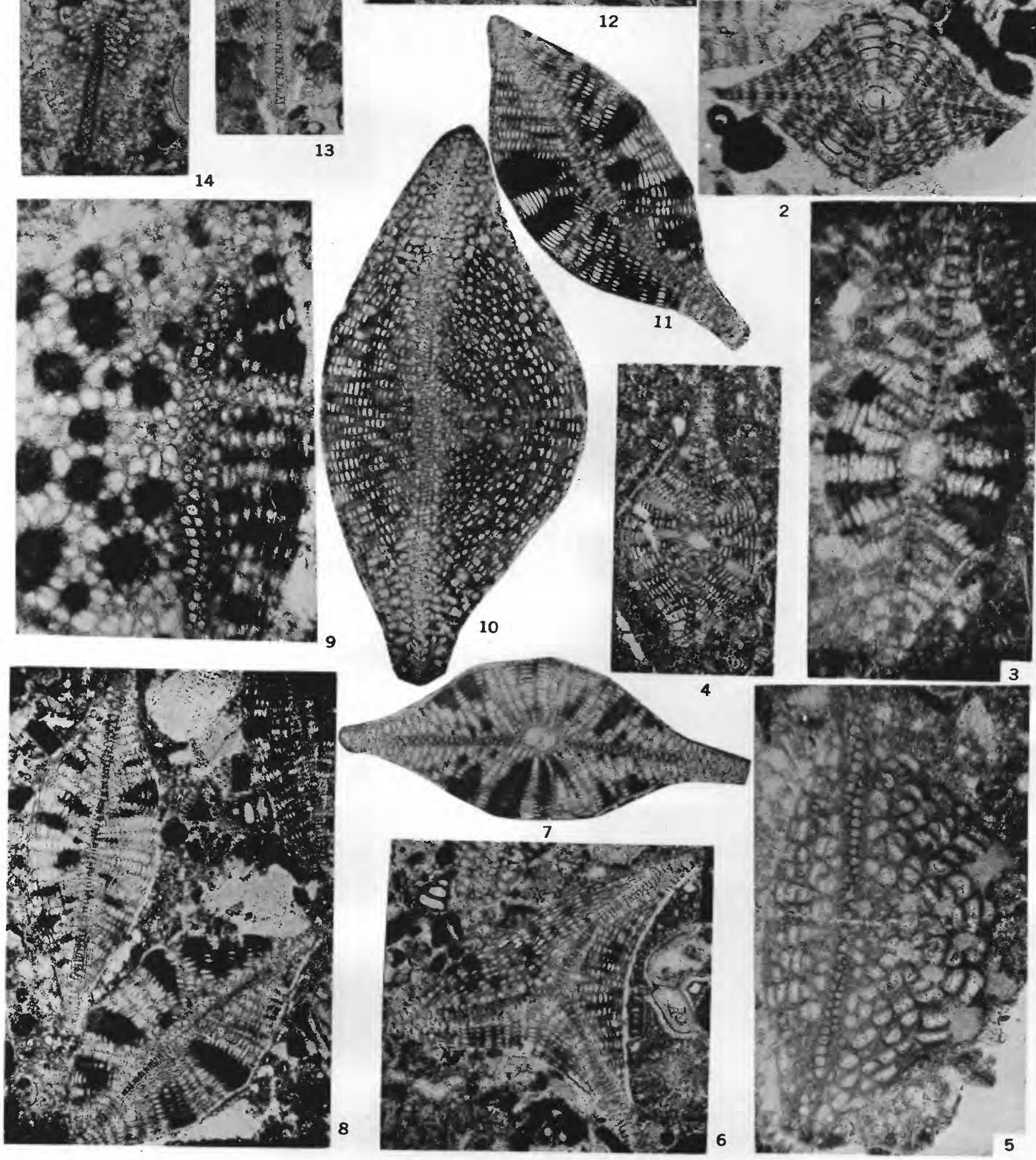


\section{PLATE 11}

FIGURES 1, 2. Lepidocyclina (Nephrolepidina) parva Oppenoorth (p. 30).

1, 2. Vertical sections, $\times 40$, station $S-13$.

3. Lepidocyclina (Nephrolepidina) brouweri L, Rutten (p. 28)

3. Lepidocyclina (Nephrolepidina) brouweri $L$, Rutten (p. 28).

4, 5. Lepidocylina (Nephrolepedina) sumatrensis (Brady) (p. 32).

5. Oblique equatorial section, $\times 40$, showing the shape of the equatorial chambers, station $\mathrm{S}-3$.

6-14. Lepidocyclina (Nephrolepidina) verbeeli Newton and Holland (p. 33).

6. Random section, $\times 16$, of a trigonal form, station $S-33 a$.
7. Strongly oblique section, $\times 16$, showing embryonic chambers and the lateral chambers, station $S-33 c$.

8. Random vertical sections, $X 16$, of two megalospheric individuals, station $S-33 a$.

9. Oblique equatorial section, $\times 40$, showing the shape of the equatorial chambers, station S-33c.

10. Oblique equatorial section of an apparently microspheric individual, $\times 16$, showing the lateral and equatorial chambers, station $\mathrm{S}-33 \mathrm{a}$.

1. Random vertical section of a megalospheric individual, $\times 16$, showing lateral chambers and pillars, station $S-33 c$

(teration S-33a. 
PLATE 12

Ficure 1. Asterocyclina sp. (p. 37).

Vertical section, not centered, $\times 4 \mathrm{U}$, station $\mathrm{S}-24$

Asterocyclina sp. (p. 37).

Vertical section, not centered, $\times 40$, station S-24.

3. Discocyclina sp. A (p. 37).

Vertical section, centered, $\times 40$, station $\mathrm{S}-24$.

4. Discocyclina sp. B (p. 37).

5, 14. Lepidocyclina (Nephrolepidina) brouweri L. Rutten (p. 28),

5 . Oblique vertical section, $\times 40$, station $\mathrm{S}-34 \mathrm{~b}$.

6. 14. Strongly oblique section, $x 40$, showing equatorial chambers and wide flange, station S-34c.

6. Lepidocyclina (Nephrolepidina) parva Oppenoorth (p. 30).

7, 12, 13. Lepidocyclina (Nephrolepidina) verbeeki Newton and Holland (p. 33).

7. Vertical section, not centered, probably near periphery of the test, $\times 40$, station S-33bc.

12. Vertical section of a young specimen and Textularia SD., $\times 40$ station S-33a.

13. Oblique vertical section near the periphery, $\times 16$, station $\mathrm{S}-33 \mathrm{bc}$

8. Oblique equatorial section, $\times 16$, showing embryonic and equatorial chambers, station $\mathrm{S}-13$

9. Equatorial section, not centered, $\times 16$, station S-13.

10. Vertical section, not centered, $\times 16$, station $\mathrm{S}-13$.

15. Vertical section, not centered, $X 16$, station $\mathrm{S}-13$

Transverse section, not centered, $\times 16$, station S-33a.

16. Borelis pygmaeus (Hanzawa), right, and Lepidocyclina (Nephrolepidina) parva Oppenoorth, left, $\times 40$, station S-13 (p. 27 ). 

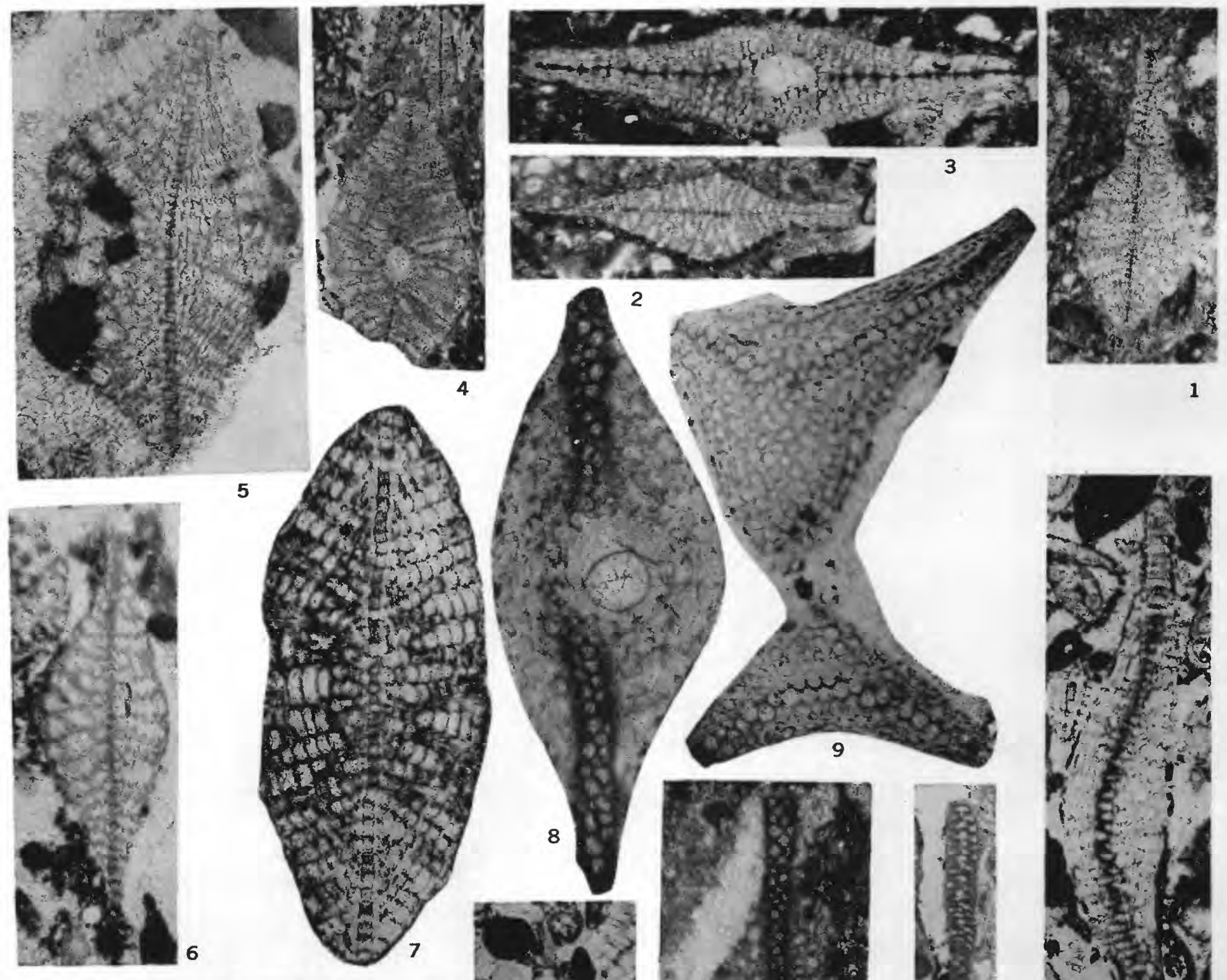

3
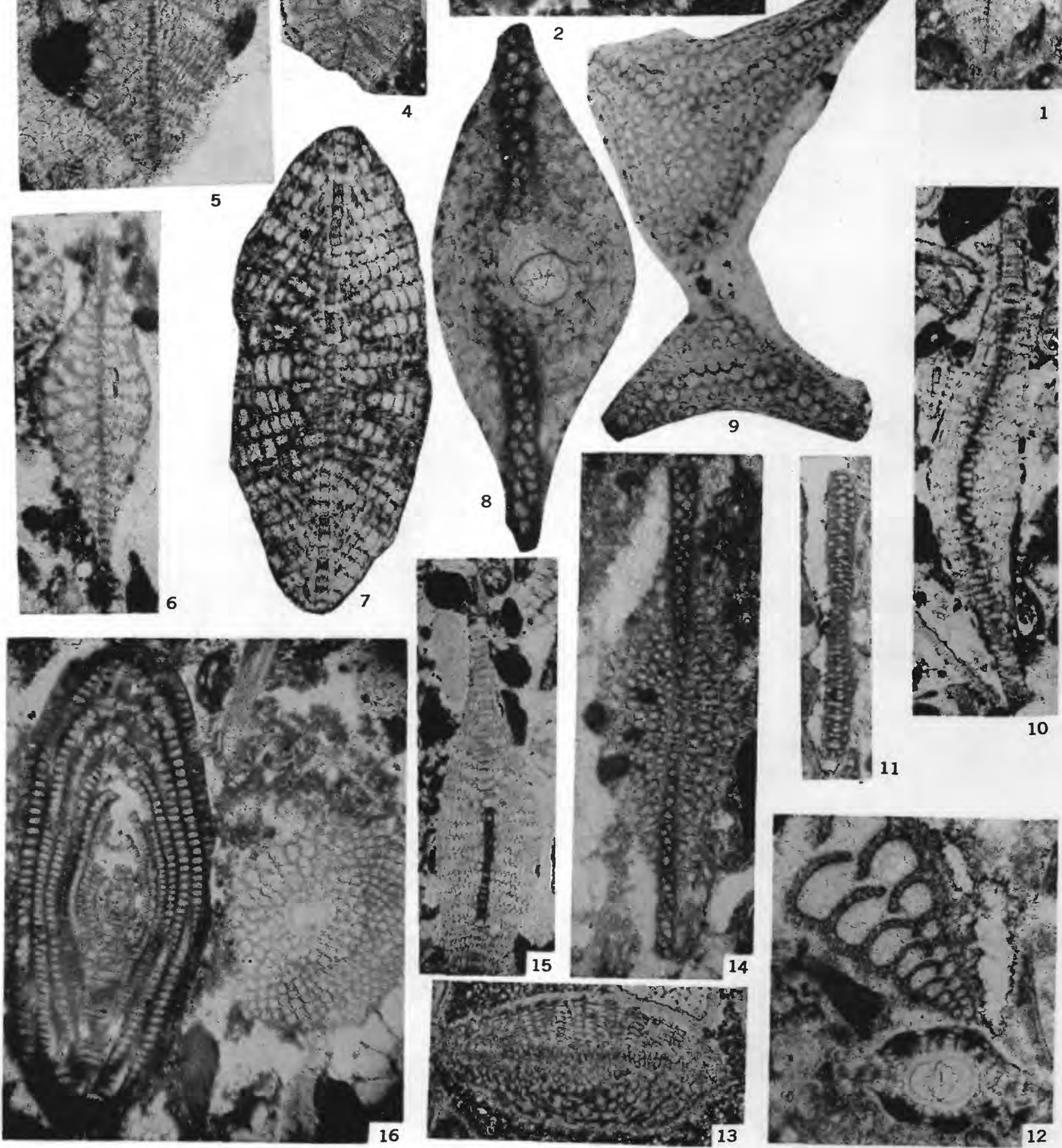

ASTEROCYCLINA, DISCOCYCLINA, LEPIDOCYCLINA, SORITES, AND BORELIS 


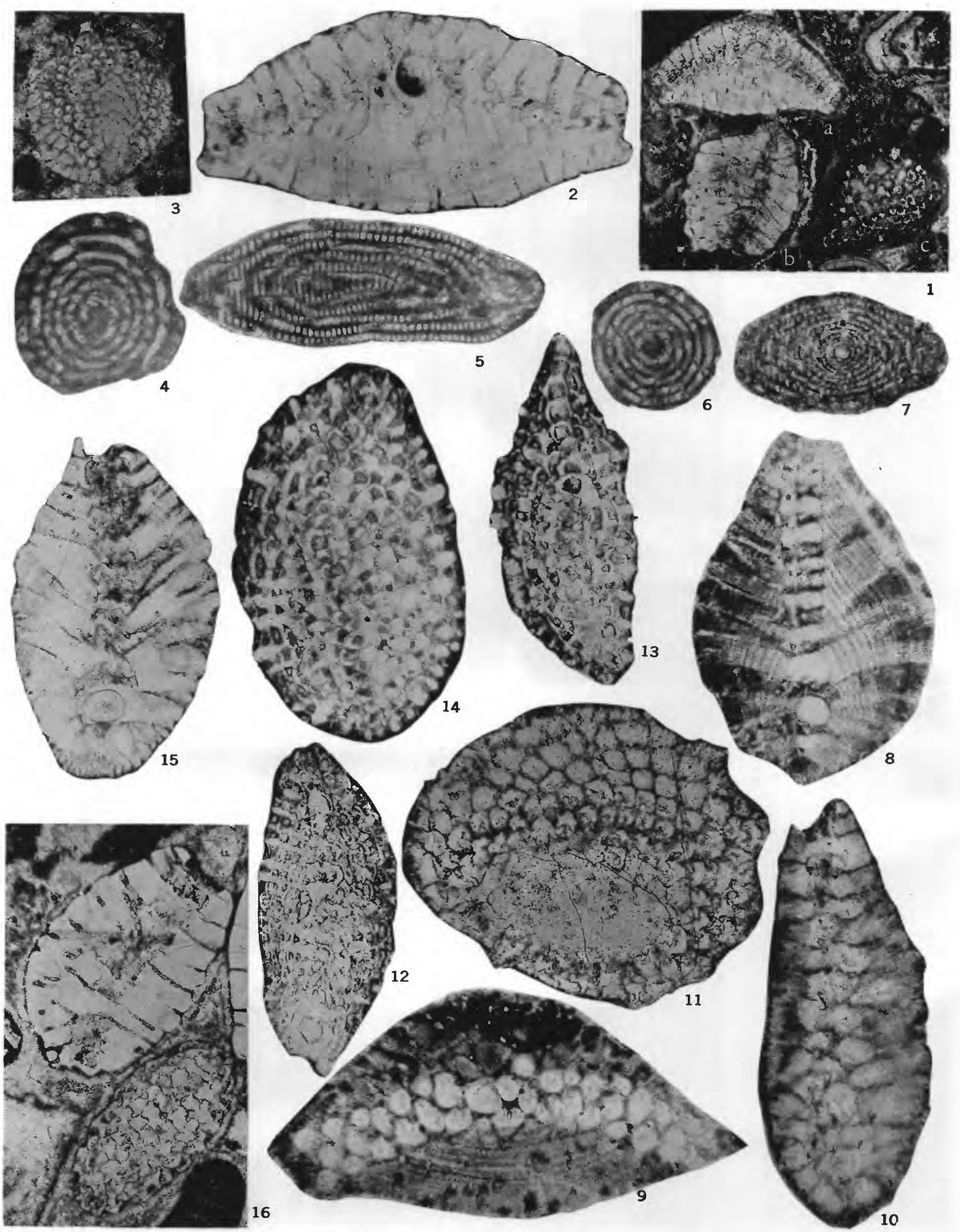

MIOGYPSINOIDES, MIOGYPSINA, AND BORELIS 


\section{PLATE 13}

Fifures 1-3, 10, 11, 15, 16. Miogypsinoides formosensis Yabe and Hanzawa (p. 38)

1. Oblique vertical section showing the embryonic chambers, the vertical canals, and the pillars which transverse the walls; $b$, fragment showing vertical canals; $\mathrm{e}$, Miogypsina inflata Yabe and Hanzawa, oblique equatorial section showing some of the equatorial chambers and the pattern of pillars, $\times 16$, station $\mathrm{S}-33 \mathrm{bc}$.

2. Oblique vertical section, $\times 40$, station $\mathrm{S}-33 \mathrm{be}$

3. Equatorial section, nearly centered, $\times 16$, showing embryonic, peri-embryonic and equatorial chambers, station S-33a

10. Oblique vertical section, $\times 40$, showing embryonic and equatorial chambers and the structure of the walls covering the equatorial layer, station S-34b.

11. Oblique equatorial section, $\times 40$, showing the shape of the equatorial chambers, station S-33a.

15. Vertical section, centered, $\times 40$, station S-33bc

16. Upper figure, vertical section, not centered, $\times 40$, station $\mathrm{S}-33 \mathrm{bc}$

16. Miogypsina (Miogypsina) mamillata Yabe and Hanzawa (p. 38)

Lower figure, oblique vertical section, not centered, $\times 40$, station S-33bc.

4-7. Borelis pygmaeus (Hanzawa) (p. 27).

4. Transverse section, not centered, $\times 40$. station $\mathrm{S}-13$.

5. Longitudinal section, not centered, $\times 40$ station $S-13$.

Transverse section, not centered, $\times 40$, station $\mathrm{S}-13$

single chambered embryonic apparatus, station S-13.

8 . Vertical section, $\times 40$, showing embryonic chambers, the heavy pillars embedded in the lateral walls and the intervening fibrous areas, station 8. $\mathrm{S}-33 \mathrm{c}$.

Oblique equatorial section, $\times 40$, showing the shape of the equatorial chambers, station S-330.

12-14. Miogypsina (Miogypsina) inflata Yabeand Hanzawa (p. 37)

12. Vertical section, centered, $\times 40$, station $\mathrm{S}-33 \mathrm{bc}$.

14. Strongly oblique section, $\times 40$, that shows equatorial chambers as well as lateral cham bers, station $\mathrm{S}-33 \mathrm{bc}$. 
FIgURES 1, 2. Soriles martini (Verbeek) (p. 27).

\section{PLATE 14}

1. Part of vertical section shown in figure $2, \times 40$, station S-33a.

3. Lexidocyclina (Nephrolepidina) newtoni Yabe and Hanzawa. (p. 29)

ateral chambers, station $\mathrm{S}-13$

ctoriella plecte (Chapman). (p. 28)

5,6. Cycloclypeus (Cycloclypeus) carpenteri Brady (p. 26).

5. Vertical section, centered $\times 16$, station T-7 Tinian showing the salient features of this species.

6 . Vertical section, not centered, $\times 16$, station $T-7$. Tinian.

7. Spiroclypeus sp. (p. 18)

8. Vertical section, nearly centered, $\times 16$, station $\mathrm{S}-18$.

Equatorial section, not exactly centereo, $\times 40$, showing embryonic, peri-embryonic, and equatorial chambers, station S-33e.

9, 10. Miogypsinoides abunensis (Tobler) (p.38)

9. Portion of the wall of the specimen illustrated as figure $10, \times 40$, showing the pillars, station S-33a.

11. Miogypsina (Miogypsina) irregularis (Michelotti) teste (Yabe and Hanzawa) (p. 38)

12. Austrotrillina how chini (Schlumberger) (p. 20).

Section showing cribrate wall strueture, $\times 40$, station $\mathrm{S}-33 \mathrm{bc}$. 


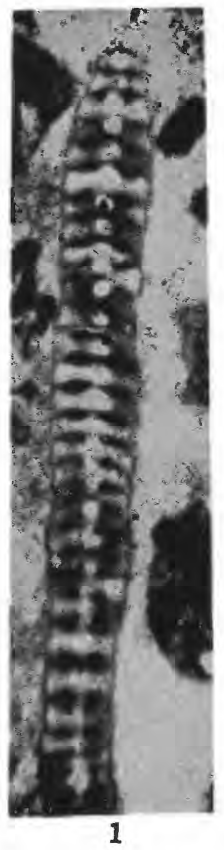

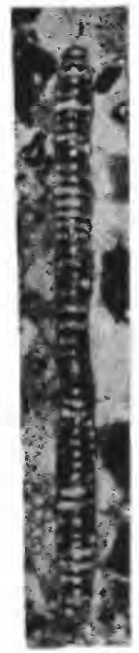

2

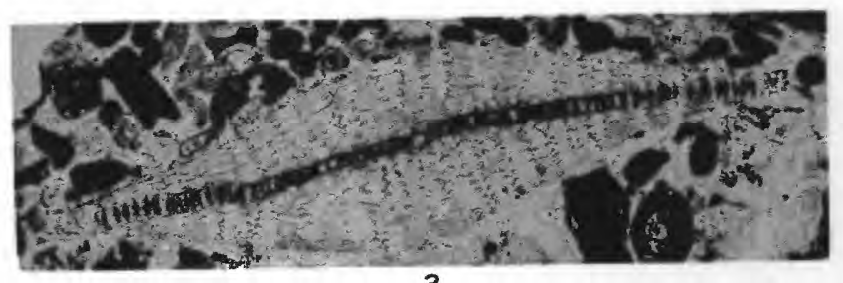

3

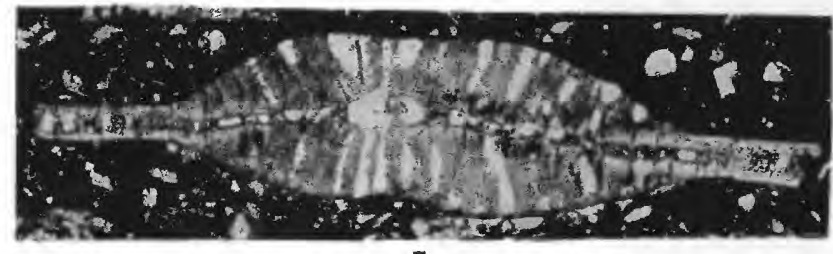

5
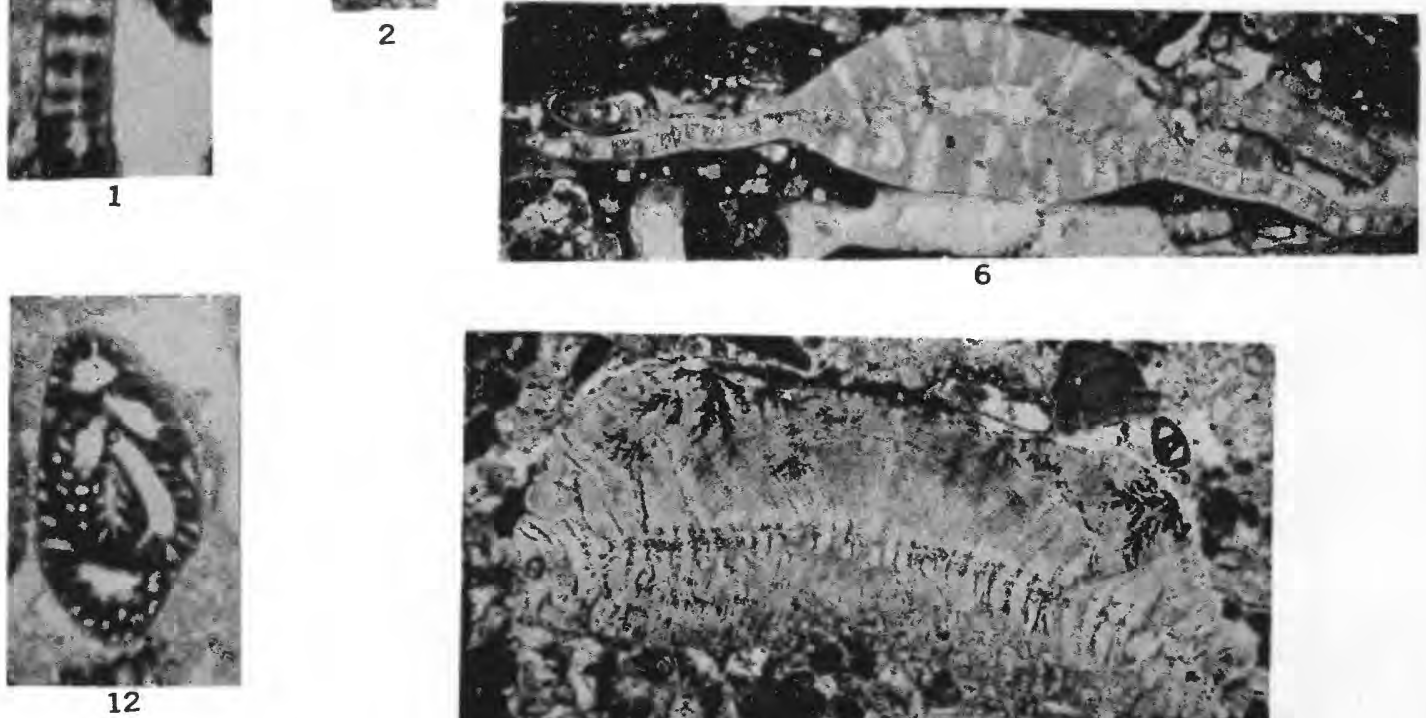
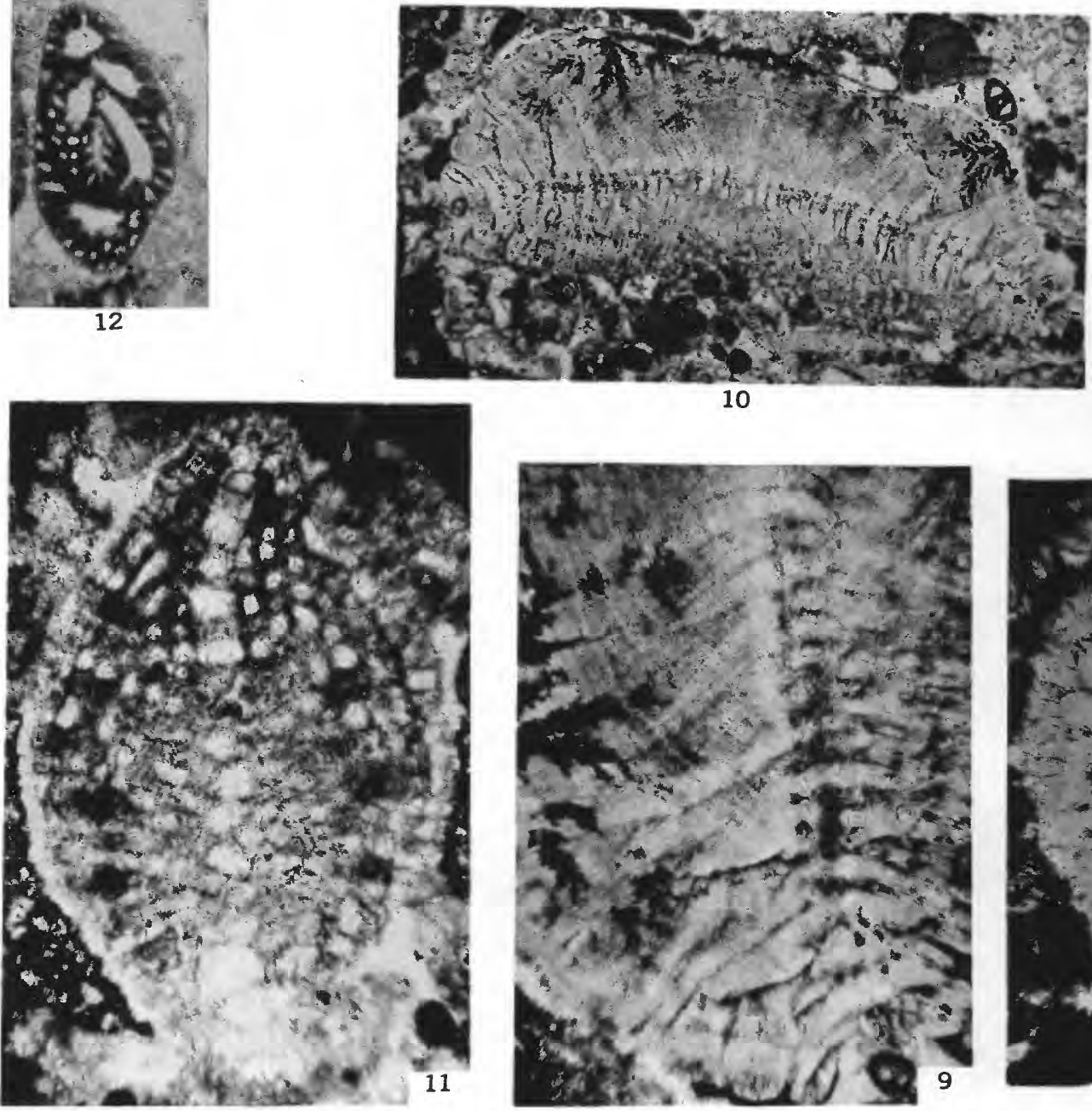

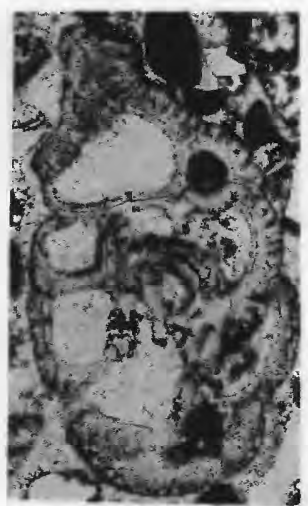

4
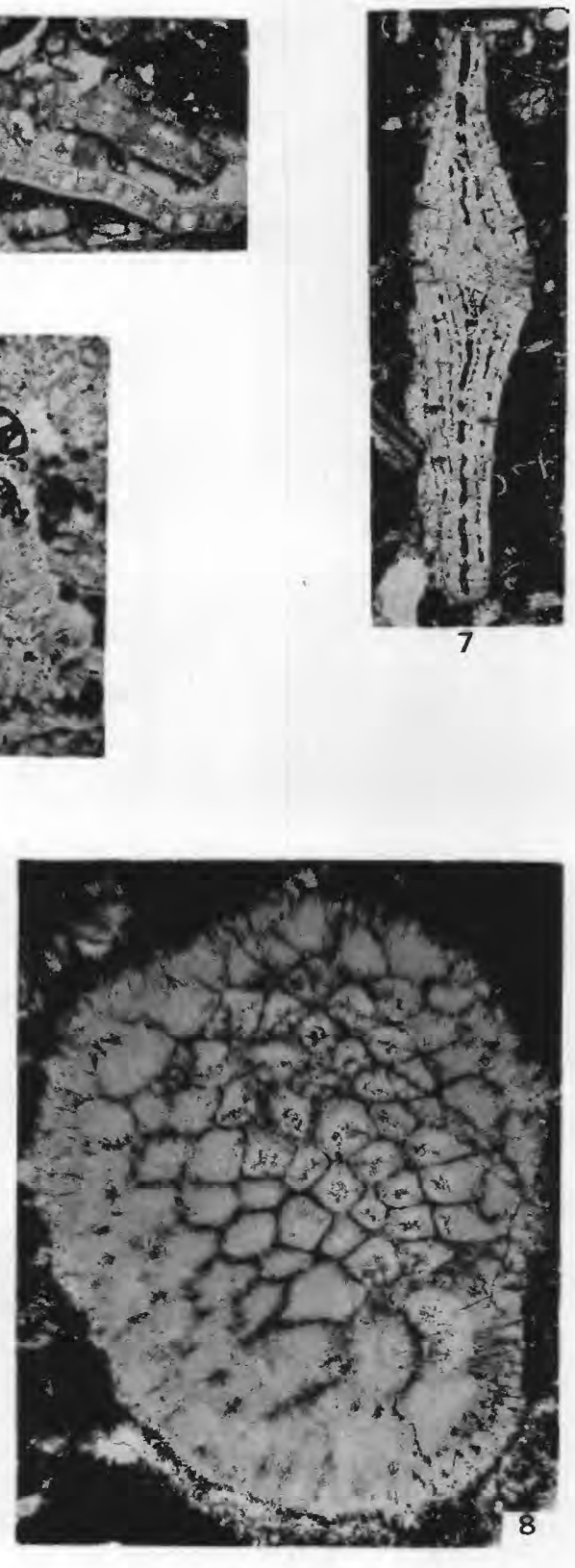

SORITES, LEPIDOCYCLINA, VICTORIELLA, CYCLOCLYPEUS, SPIROCLYPEUS, MIOGYPSINOIDES, MIOGYPSINA, AND AUSTROTRRILLINA 

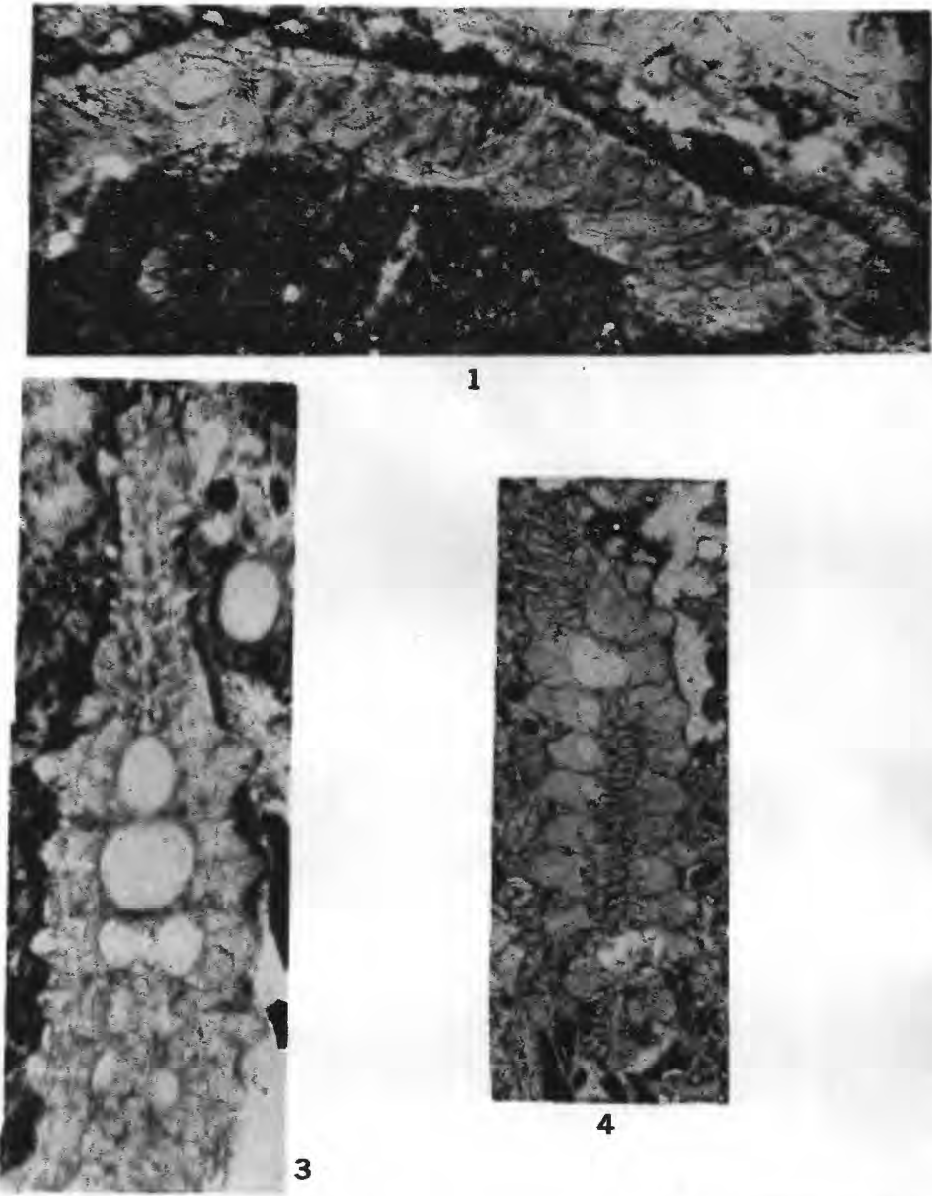

1
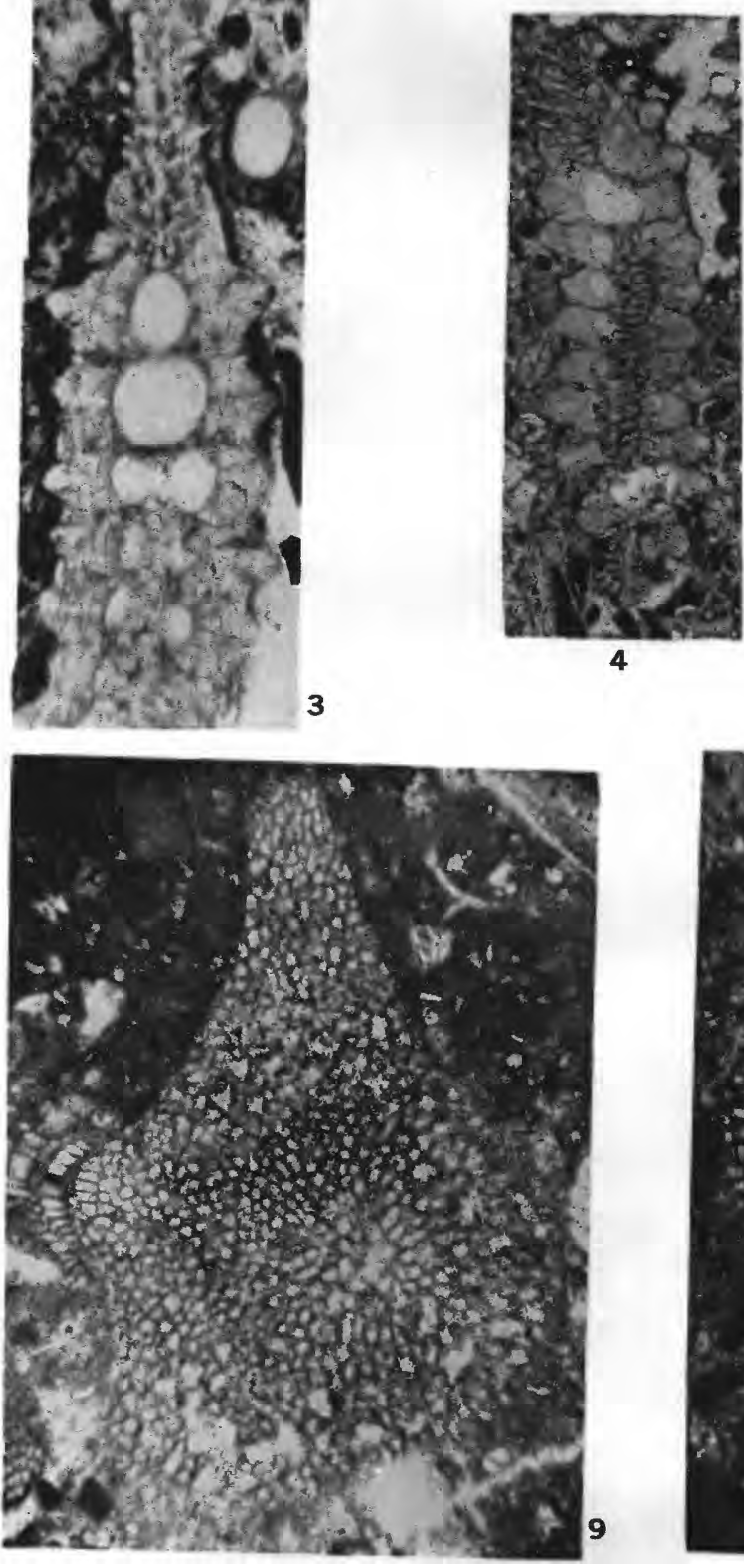
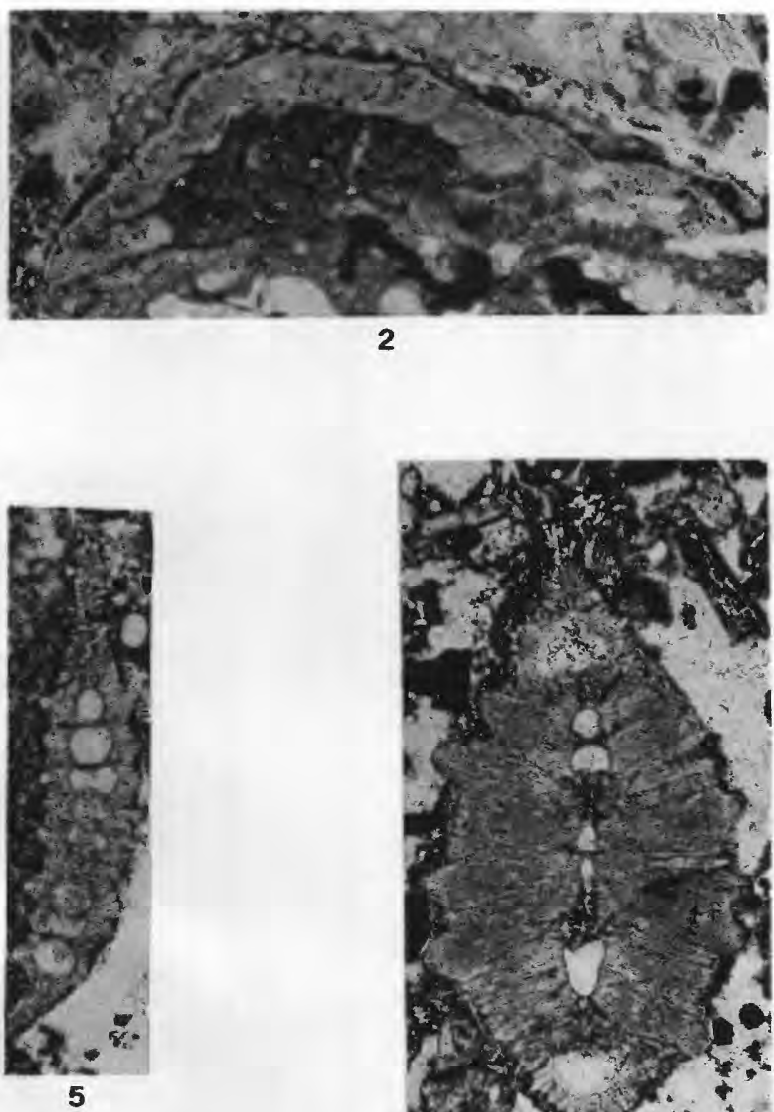

2
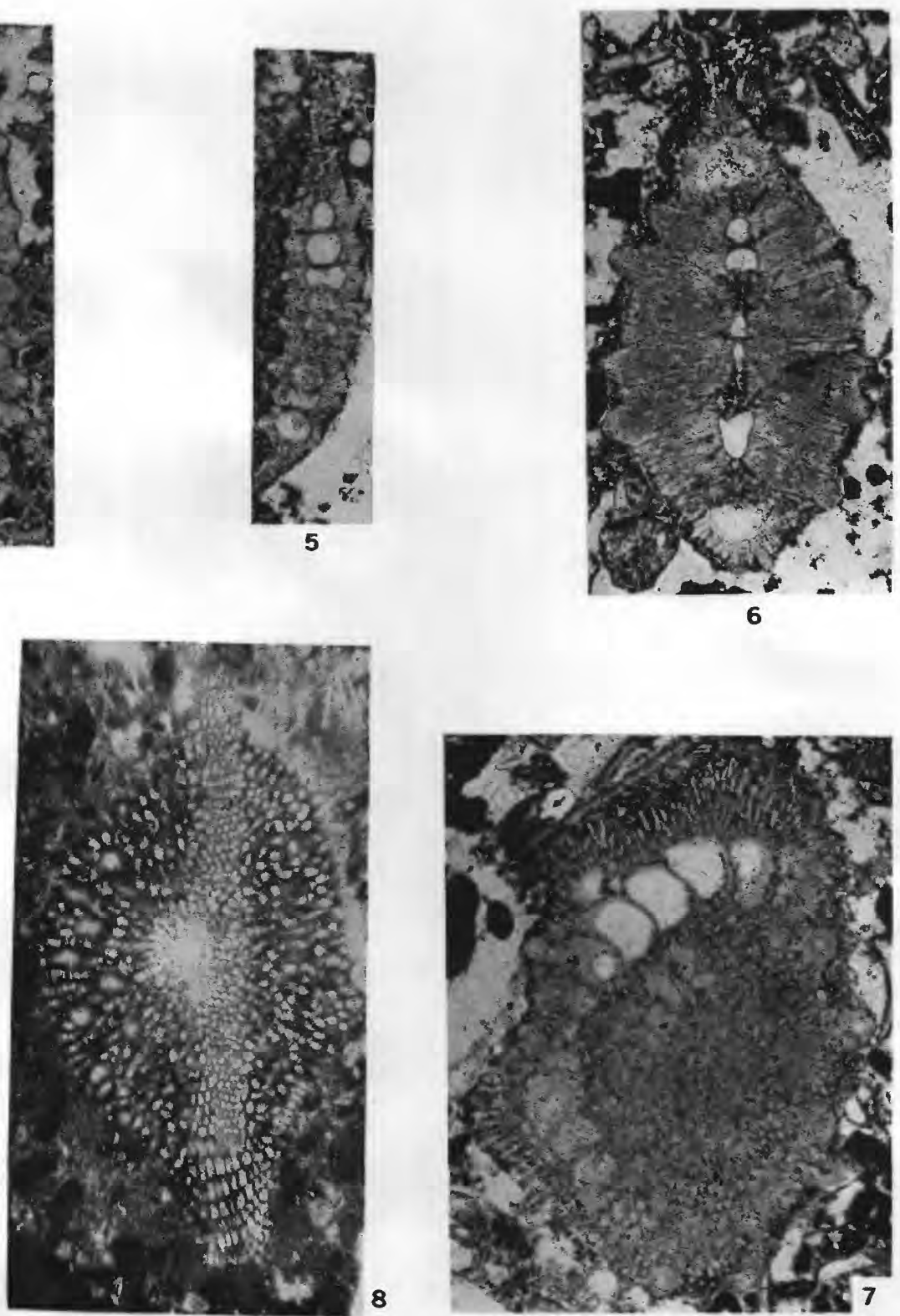

FABIANA, PELLATISPIRA, AND ASTEROCYCLINA 


\section{PLATE 15}

Figures 1, 2. Fabiania saipanensis Cole, n. sp. (p. 28).

1. Part of transverse section of the holotype, $\times 40$, showing the embryonic chambers, the structure of the wall and the chamberlets, station S-32c, U.S.N.M. Transverse section of the holotype, $\times 16$, station S-32c, U.S.N.M. 560276.

3-7. Pellatispira crassicolumnata Umbgrove (p. 21)

3. Part of transverse section shown on figure $5, \times 40$, station $\mathrm{S}-32 \mathrm{c}$.

4. Oblique transverse section, $\times 16$, not centered, showing the very heavy pillars, station $\mathrm{S}-32 \mathrm{c}$.

5. Transverse section, $\times 16$, not centered, station S-32c. The apparent double layer in the median zone is the result of the position of the section. The apparent dividing plane is part of the revolving wall between the whorls of the median chambers.

6. Transverse section, $\times 16$, nearly centered, of a thick specimen, station S-32c.

8, 9. Asterocyclina sp. (p. 37 ) , showing the equatorial chambers, station S-32c.

. Oblique equatorial section, $\times 40$, that passes almost through the center, station $\mathrm{S}-18$.

9. Oblique equatorial section, $\times 40$, showing the radiate configuration of the equatorial chambers and of the test, station S-18. 
